ROSANA APARECIDA DALLA PIAZZA

\title{
O REFLEXO DA ARTE EM INHOTIM
}

Dissertação apresentada ao Programa de PósGraduação Interunidades em Estética e História da Arte (PGEHA USP) para obtenção do título de Mestre em Estética e História de Arte.

Orientadora: Profa. Dra. Elza Ajzenberg

Linha de Pesquisa: Teoria e Crítica da Arte.

São Paulo

Novembro de 2019 
ROSANA APARECIDA DALLA PIAZZA

\section{O REFLEXO DA ARTE EM INHOTIM}

Dissertação apresentada ao Programa de PósGraduação Interunidades em Estética e História da Arte (PGEHA USP) para obtenção do título de Mestre em Estética e História de Arte.

Orientadora: Profa. Dra. Elza Ajzenberg

Linha de Pesquisa: Teoria e Crítica da Arte. 
Autorizo a reprodução e divulgação total ou parcial deste trabalho, por qualquer meio convencional ou eletrônico, para fins de estudo e pesquisa, desde que citada a fonte.

Catalogação na Publicação

Serviço de Biblioteca e Documentação

Faculdade de Filosofia, Letras e Ciências Humanas da Universidade de São Paulo

P $584 r$

Piazza, Rosana Aparecida Dalla

O reflexo da arte em Inhotim / Rosana Aparecida

Dalla Piazza ; orientadora Elza Ajzenberg. - São

Paulo, 2020 .

$119 \mathrm{f}$.

Dissertação (Mestrado) - Programa de Pós-Graduação

Interunidades em Estética e História da Arte da

Universidade de São Paulo. Área de concentração:

Estética e História da Arte.

1. Arte Contemporânea - Brasil. 2. Espelho. 3. Instituto Inhotim. 4. Soares, Valeska, 1957-. 5. I. Ajzenberg, Elza, orient. II. Título. 
Nome: Rosana Aparecida Dalla Piazza

Título: O reflexo da arte em Inhotim (ME).

Dissertação apresentada ao Programa de Pós-Graduação Interunidades em Estética e História da Arte (PGEHA USP) para obtenção do título de Mestra em Estética e História da Arte.

Orientadora: Profa. Dra. Elza Ajzenberg.

Linha de Pesquisa: Teoria e Crítica da Arte.

Aprovado em:

Banca Examinadora

Orientador: Prof. Dr.

Instituição: Assinatura:

Prof. Dr. Instituição:

Julgamento: Assinatura:

Prof. Dr. Instituição:

Julgamento: Assinatura:

Prof. Dr. Instituição:

Julgamento: Assinatura: 


\section{AGRADECIMENTOS}

Agradeço profundamente ao meu companheiro de jornada terráquea Ariton Omar Simis que foi meu staff - incentivador e boa alma de enorme paciência.

Agradeço profundamente à querida Elza Ajzenberg que me orientou e continua orientando-me. Obrigada pelas palavras, conselhos e ensinamentos tão ricos.

À CAPES, pela bolsa concedida.

Agradeço profundamente à Alecsandra Matias e ao Marcelo Vieira Fernandes pela amizade, orientações acadêmicas, confiança, alegria, criatividade e inspiração.

Segundo o filósofo Antístenes, "a gratidão é a memória do coração" e é onde vocês estão. 


\begin{abstract}
RESUMO
O presente estudo tem como primeira motivação explorar o uso do espelho e do espelho d'água ao longo da História da Arte. Nas produções artísticas, algumas vezes, o espelho remete aos mitos greco-romanos, em outras se apresenta como retrato e autorretrato, isto porque o espelho é o estado atual do indivíduo que se "reflete" (aquele que especula, speculum, espelho). Nos retratos e autorretratos, o espelho é o ponto de partida para o conhecimento da pessoa que a imagem representa. Imerso nesse contexto, como recorte desta pesquisa selecionou-se a instalação Folly (2005-2009) de Valeska Soares, que através de espelhos d'água e espelhos interativos conversa com o seu entorno - o acervo do museu a céu aberto, Inhotim, localizado no município de Brumadinho (MG). Nesse recorte, discutem-se as similaridades dos espelhos e dos reflexos em consonância com os espelhos d’água do Jardim Botânico de Inhotim. Tem-se ainda grande atenção sobre a abordagem da artista diante da temática dos reflexos e dos espelhos em diálogo com a natureza, enfatizando, sobretudo, o conceito de construção e destruição das identidades. Assim sendo, colocam-se as questões centrais desta investigação: qual a importância do recurso do espelho no fazer artístico contemporâneo por essa artista? Como a representação do espelho cria um percurso especular na obra de Soares em Inhotim? Como se dá o processo criativo a partir do reflexo do espelho? E como se produz esse mecanismo especular entre as obras e o espaço natural? A partir dessas indagações, esta pesquisa apresenta dualismo dinâmico entre natureza e arte, sutilmente coreografado para facilitar as performances ritualísticas do público que, ao vivenciar a arte é transformado pela interatividade - mesmo que essa experiência seja transitória e que, no fim do dia, se retorne para casa.
\end{abstract}




\begin{abstract}
The present study has as its first motivation to explore the use of the mirror and the water mirror throughout the history of art. In artistic productions, sometimes the mirror refers to Greco-Roman myths, sometimes it is presented as a portrait and self-portrait, because the mirror is the current state of the individual who "reflects" (the speculator, speculum, the mirror). In portraits and self-portraits, the mirror is the starting point for knowledge of the person the image represents. Immersed in this context, as part of this research was selected the installation Folly (2005-2009) of Valeska Soares, which through water mirrors and interactive mirrors talks with its surroundings - the collection of the open-air museum, Inhotim, located in the municipality of Brumadinho (MG). In this section, we discuss the similarities of mirrors and reflexes in line with the water mirrors of the Inhotim Botanical Garden. There is also great attention on the artist's approach to the theme of reflexes and mirrors in dialogue with nature, emphasizing, above all, the concept of construction and destruction of identities. Thus, the central questions of this investigation are: what is the importance of the mirror's appeal in the contemporary artistic making by this artist? How does the representation of the mirror create a specular path in Soares's work in Inhotim? How does the creative process take place from the reflection of the mirror? And how is this specular mechanism produced between works and natural space? From these questions, this research presents a dynamic dualism between nature and art, subtly choreographed to facilitate the ritualistic performances of the public who, when experiencing art is transformed by interactivity - even if this experience is transitory and, at the end of the day, we return home.
\end{abstract}




\section{LISTA DE FIGURAS}

Figura 1. Artista desconhecido, Pompeia, Itália. Vila dos Mistérios, 60-50 a.C. ......... 19

Figura 2. Artista desconhecido, Pompeia, Itália. Vila dos Mistérios, 60 a.C.-50 a.C. 21

Figura 3. Câmera especular ............................................................................................ 23

Figura 4. Hieronymus Bosch. Jardim das delícias (detalhe),1480-1490 ...................... 24

Figura 5. Jan Van Eyck, O casal Arnolfini, óleo sobre tábua, 1434. ............................. 25

Figura 6. Diego Velásquez. As meninas, óleo sobre tela, 1656.................................... 27

Figura 7. Édouard Manet. Um bar em Folies-Bergère....................................................... 28

Figura 8. Espelhos d'água em Inhotim, Brumadinho/MG ................................................ 33

Figura 9. O lago de ninfeias com a ponte japonesa coberta por glicínias, Jardins de Monet................................................................................................................... 34

Figura 10. Escher. Mão com esfera refletora, 1935 .......................................................... 36

Figura 11. Helga Stein, Andros Hertz, 2004 .................................................................. 39

Figura 12. Cindy Sherman, Sem título. Bus Riders, 1976/2005 ....................................... 40

Figura 13. Jorge Molder, Autorretratos, (1979-1987) ................................................. 42

Figura 14. Vivian Maier. Autorretrato, s.d ........................................................................ 43

Figura 15. Francesca Woodman, Self-deceit, 1975 ............................................................ 45

Figura 16. Robert Smithson, Yucatan Mirror Displacements, 1969............................ 46

Figura 17. Anish Kapoor, Sky Mirror, 2006 ....................................................................... 47

Figura 18. Calçada Bastos, In the mirror suitcase man, 2004 ....................................... 48

Figura 19. Francis Bacon, Três estudos para um autorretrato, 1981 ............................. 49

Figura 20. Transformando nosso mundo: a agenda 2030 para o desenvolvimento sustentável ...................................................................................................................... 52

Figura 21. Jardim Botânico Inhotim.............................................................................. 54

Figura 22. Vista aérea de Inhotim. .......................................................................... 58

Figura 23. Benesse Art Site Naoshima, 2018 (vista aérea)............................................ 58

Figura 24. Galeria Adriana Varejão (vista externa) .......................................................... 60

Figura 25. Cristina Iglesias, Vegetation room Inhotim, 2010 .................................... 61

Figura 26. Olafur Eliasson. Viewing Machine, 2002-2008 ........................................ 62

Figura 27. Olafur Eliasson. Viewing Machine, 2002- 2008 ............................................... 62

Figura 28. Dan Graham. Bisected triangle, interior curve, 2002 ....................................... 63

Figura 29. Mathews Barney, De lama lâmina, 2009.............................................................. 64

Figura 30. Yayoi Kusama, Jardim de Narciso, 2009 ................................................. 66

Figura 31. Jorge Macchi. Piscina, 2009 ..................................................................... 67

Figura 32. Valeska Soares Vanishing point, 1998......................................................... 72 
Figura 33. Valeska Soares Untitled (From vanishing point), 1996.............................. 73

Figura 34. Valeska Soares. Detour, 2002 ................................................................................... 74

Figura 35. Valeska Soares. Série Narcissus I, II, III, 2005 .............................................. 75

Figura 36. Valeska Soares. Puro teatro, 2003.......................................................................... 78

Figura 37. Valeska Soares. Picturing Paradise, 2000...................................................... 80

Figura 38. Valeska Soares. Self portrait in Denial, 2004-2018...................................... 82

Figura 39. Valeska Soares, Folly, 2005-2009 ................................................................... 84

Figura 40 Valeska Soares, Folly, 2005-2009 .................................................................... 88

Figura 41. Valeska Soares, Folly, 2005-2009 ..........................................................8 88 


\section{SUMÁRIO}

INTRODUÇÃ

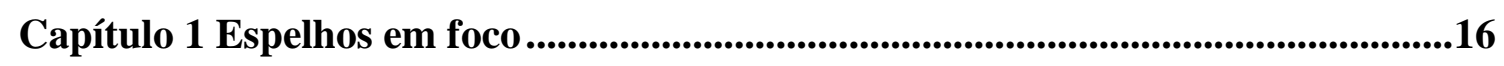

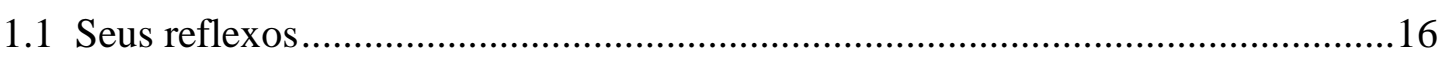

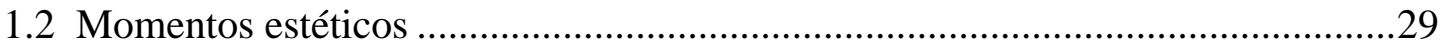

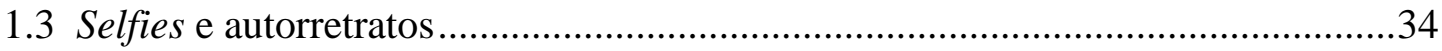

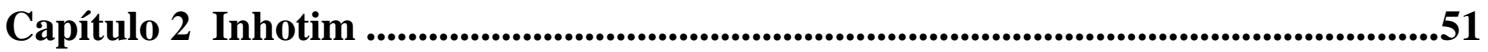

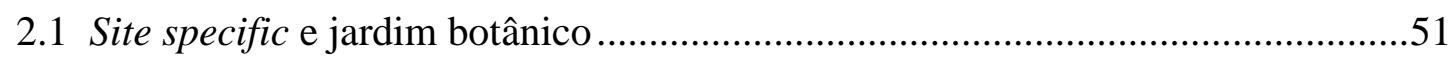

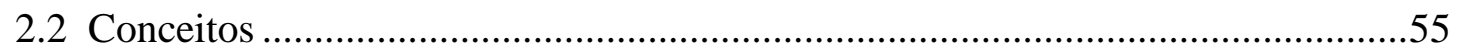

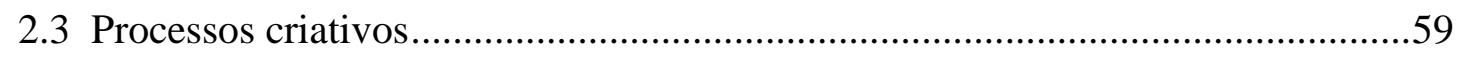

Capítulo 3 Valeska Soares ....................................................................................................69

3.1 Trajetória pessoal e artística ..............................................................................69

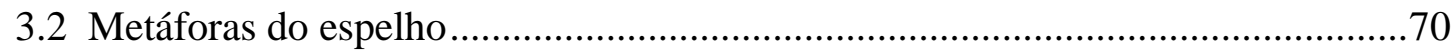

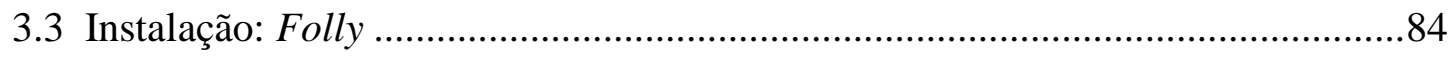

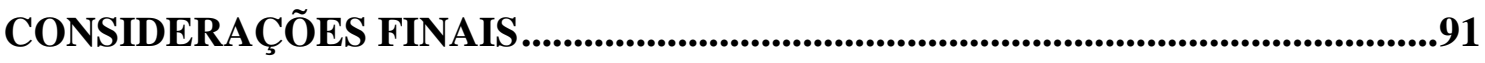

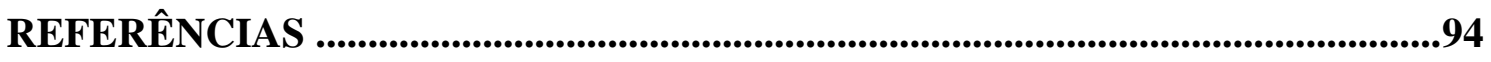

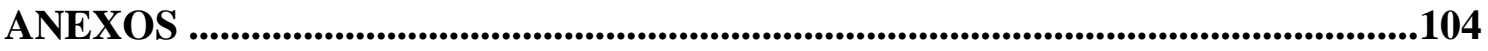




\section{INTRODUÇÃO}

Observar-se no espelho é uma ação cotidiana aos seres humanos: quer seja por asseio, quer seja por aprimoramento da própria imagem. Existe uma relação primordial entre a vida contemporânea e o próprio espelho. Talvez, todo aquele que reflete está interessado no espelho. Conforme o pensador Flusser, o espelho é um instrumento no qual se especula (de speculum $=$ espelho) (FLUSSER, 1998, p.67). Em autores como Guimarães Rosa, observa-se o medo associado aos espelhos:

Sim, são para se ter medo, os espelhos. Temi-os, desde menino, por instintiva
suspeita. [...] na nossa terra, diz-se que nunca se deve olhar em espelho às
horas mortas da noite, estando-se sozinho. Porque, neles, às vezes, em lugar
de nossa imagem, assombra-nos alguma outra e medonha visão. [...].
Satisfazer-me com fantásticas não explicações? - jamais. Que amedrontadora
visão seria então aquela? Quem o monstro? (ROSA, 2005, p. 77).

Tais considerações levam aos questionamentos: quem aparece no espelho? Quem sou eu? Difícil responder essas duas perguntas, que, por sua vez, desencadeiam uma terceira tão ou mais complexa: quem é você? (BERNARDO, 2013, p.172). O próprio termo "pensamento" já diz muito, uma vez que os pensamentos também podem ser chamados de "reflexões". Não se diz por aí que quem pensa está refletindo sobre algo? Ou será que está refletindo algo? (BERNARDO, 2013, p.173).

A partir desses aspectos e indagações, a presente pesquisa discute as implicações estéticas do emprego do espelho nas artes visuais, tomando como referencial o Centro de Arte Contemporânea Inhotim, localizado em Brumadinho (MG). Diante do universo continuum do espelho - aqui se note que esse objeto sempre esteve ligado às sensações e inquietações, dentre elas o temor, como menciona Guimarães Rosa - esta investigação compreende a interação entre o objeto-espelho, a natureza/Inhotim e a arte. Nesse sentido, à primeira vista, pode parecer complexo estabelecer um foco para o assunto "espelho". Contudo, por intermédio de visitas técnicas ao Instituto Inhotim, tem-se a pontuação de obras que resvalam no emprego desse material, entre elas, estão: a galeria de Adriana Varejão; a instalação Folly, de Valeska Soares; Jardim de Narciso, de Yayoi Kusama; Vegetation room Inhotim, de Cristina Iglesias; Viewing Machine, de Olafur Eliasson e Bisected Triangle/Interior curve, de Dan Grahan.

A partir desse levantamento de possibilidades, destaca-se a obra Folly (20052009), de Valeska Soares (Belo Horizonte, 1957). A instalação Folly (2005-2009) tem 
uma estrutura que se difere das demais, por seu posicionamento espacial: a obra se encontra num espelho d' água - posição geográfica que afeta a percepção do olhar do espectador; ela está no centro do jardim botânico de Inhotim. A instalação também apresenta metáforas e simbologias. Sendo formada por paredes de espelho, o espectador, ao se aproximar da instalação, é tomado pelos efeitos oculares, de que as paredes são vazadas; no fundo, as paredes da obra estão camufladas em meio ao verde, criando um efeito de trompe l'oeil ${ }^{1}$. Nesse sentido, tudo o que está no entorno da obra sofre a variação do olhar do espectador, isto porque distância e posição onde o espectador se encontra interfere na sua percepção.

Sobre um deck de madeira, Folly (2005-2009) é um octógono espelhado com uma porta que leva espectador para o lado interno da obra. Do lado de dentro, há uma sala escura com um vídeo projetado nas paredes. Nesse vídeo, com trilha sonora, existem dançarinos infinitamente refletidos pelos espelhos internos da obra. A própria caminhada para se chegar ao local, somada aos efeitos externos e a virtualidade interna provocam diferentes alterações sensoriais no espectador. Sendo assim, a instalação Folly tem como potencialidade o diálogo entre jardim/obra/espelho. Aqui, assinala-se que o tema e o emprego do espelho surgem em outras obras da artista. Nelas, existem múltiplas facetas especulares que evocam diversas percepções na experiência do público. Porém, Folly (2005-2009) pode ser tomado como exemplar dessas práxis da artista.

Já Inhotim, em Minas Gerais, é um local especial: é um parque ecológico; um jardim botânico e um museu de arte com os jardins paisagísticos encantadores. Tem instalações de arte a céu aberto, um lugar de renovação constante da natureza. Assim, nesse espaço as obras de arte somadas ao jardim dispõem, preservam e divulgam a história socioambiental brasileira, tornando-se patrimônio cultural que, simultaneamente, serve ao desenvolvimento de ações científicas e educacionais. É um lugar que está sujeito às ações conservacionistas ecológicas e voltadas à biodiversidade vegetal. Em 2009, Inhotim é reconhecido como o jardim botânico pela Comissão

\footnotetext{
${ }^{1}$ Em português, quer dizer "engana o olho". O trompe l'oeil é um jogo em que o espectador caminha entre a realidade e a ficção. Há grandes mestres da arte ilusória. No Capítulo 1.2, observe Maurits Cornelis Escher (1898-1972). Disponível em: < https://jpcnortonm.wordpress.com/2017/08/13/trompeloeil-arte-e-ilusao/> Acesso em: 29 nov. 2019.
} 
Nacional de Jardins Botânicos (CNJB) ${ }^{2}$. Nesse sentido, a partir da dualidade entre jardim e museu, esta pesquisa busca as essências conectadas entre si.

Para a análise do virtual especular que envolve este estudo, destaca-se a reflexão de Umberto Eco, na obra Fenomenologia do Espelho (1989), na qual, para o autor, o ser humano se habituou a inverter a imagem retilínea, isto é, o espelho como um fenômenolimiar delimita o simbólico e o imaginário. Para além das considerações de Eco (1989), nesse ponto, para esta investigação, torna-se importante a definição de espelho como toda e qualquer superfície regular, extremamente polida, localizada na fronteira de dois meios ópticos, capaz de refletir a radiação luminosa que dela incide; isso também se aplica a superfície da água.

Observe-se que, na imagem virtual, o espectador tem a sensação de estar "dentro" do espelho, quando o espelho, obviamente, não tem interior. Note-se ainda a simetria inversa, na qual o espelho põe à direita o que está à esquerda e vice-versa, porém, não o alto pelo baixo (ECO, 1989, p.14). Eco compara o espelho com uma prótese do tipo extensiva, como uma lente, ou intrusiva, como no periscópio ou certos espéculos usados pelos médicos. Para ele, o espelho se presta para ambos os usos. Serve para aumentar o alcance dos olhos ou, ainda, como en abîme do cabeleireiro.

O espelho reflete a direita exatamente onde está à direita e a esquerda onde está à esquerda. É o observador (ingênuo, mesmo quando físico por profissão) que por identificação imagina que é o homem dentro do espelho e, vendo-se, se dá conta de que traz, por exemplo, o relógio no pulso direito. Mas o fato é que só o traria se ele, o observador, fosse aquele que está dentro do espelho (Je est unautre). (ECO, 1989, p.14)

O espelho pode ampliar ou diminuir o objeto refletido. Ele pode compactar as imagens, deixando-as mais distante, permitindo ver em conjunto e, ao mesmo tempo, aquilo que não se tem como ver sem o uso dessa mediação especular. Não se pode julgar com fidedignidade seu reflexo, não se sabe dizer que espelhos distorcem o reflexo, se côncavo ou convexo. Não se sabe como julgar as variações refletidas no espelho da realidade, e, desse modo, aceitam-se todas as formas e métodos como captação de algo. Por não haver parâmetros de julgamento às proposições convive-se com todas as incertezas e não com todas as verdades (ALMEIDA, 2004).

Essa dualidade entre espelho e natureza (entre real e virtual), em Inhotim, abre uma fenda especular que se transpõe entre o imaginário e o simbólico. Desse modo, entra-se pelo espelho, mas sem ficar lá dentro. Conforme as reflexões de Eco (1989), o

\footnotetext{
${ }^{2}$ Registro aprovado após a reunião da comissão, ocorrida no Instituto de Pesquisas Jardim Botânico do Rio de Janeiro, entre os dias 24 e 26 de março de 2009.
} 
espelho se comporta como um mediador, ou seja, um meio para propagar algo ou o conhecimento.

Leve-se também em consideração, neste estudo, que as referências ao espelho na história da arte não cessam.

No Capítulo 1, apresenta-se, então, uma história da arte através do uso do espelho em diferentes épocas. Esse Capítulo relata ainda o espelho presente na produção de autorretratos. Nesta primeira etapa, está presente a premissa de que a irrupção do espelho, na história da arte, se manifesta em razão das suas características uma natureza híbrida e muitas vezes desterritorializada, dotada de portais e passagens. Outra questão discutida, no Capítulo 1 , é sobre o corpo que reflete e como as transformações e urgências contemporâneas contribuem para a formação/dissolução desse sujeito refletido no espelho. Para discutir esse tema recorre-se às teorias elaboradas por Baudrillard (1998), em Simulacro e Simulação. No mesmo capítulo, colocam-se as possíveis aproximações entre os jardins Giverny e Inhotim. Para Monet, o verdadeiro motivo das séries Nynpheias (1903) produzirem tanta luminosidade seria graças à captação de luz refletida no espelho d'água dos jardins. Através dos espelhos Inhotim, o público/espectador, vivencia uma experiência dinâmica/participativa com relações temporais dos reflexos da luz e os efeitos que produzem em cada olhar.

No Capítulo 2, discorre-se sobre o histórico de Inhotim, a fim de compreender sua formação, seu papel no panorama das artes no Brasil, bem como sua origem como Ecomuseu. Nesse contexto, são relevantes os projetos sustentáveis e como se dá o processo para se constituir como um jardim botânico de utilidade pública. Nesse Capítulo, dedicam-se atenções ao recorte espacial e suas particularidades. Assim sendo, torna-se necessário o estudo do meio, por intermédio de diversas visitas técnicas ao Instituto de Arte Contemporânea Inhotim. Foram realizadas duas visitas ao longo desta pesquisa, somando seis dias in loco que se distribuem em antes e depois do exame de qualificação deste estudo com o intuito de fazer os ajustes e recortes necessários. Antes do exame de qualificação desta investigação, são coletados dados sobre a recorrência do uso dos espelhos dentro do espaço de Inhotim e a partir disso, é realizado também o levantamento de artistas que trabalham com o espelho e espelho d'água no local.

Finalmente, no Capítulo 3, aborda-se o processo criativo de Valeska Soares, na obra Folly (2005-2012), se liga ao tema da circularidade jardim/obra/espelho. Esse processo criativo traz o espelho que se anuncia como metáfora e retomada do virtual; o duplo, selfie, autoimagem, ao ato narcísico que busca a construção de uma nova 
realidade ou hiper-realidade. Têm-se, então, relações entre natureza e reflexos que povoam as paredes do octógono Folly, produzindo múltiplas autorreflexões ao público, entre elas, a pose, o lugar e a relação com o outro. De acordo com Barthes (1984), a pose é considerada um simulacro, ou seja, uma encenação do eu como o outro. Já Foucault (1986) considera que o espelho são locais ocupados no momento que o sujeito se vê no espelho. Em contrariedade, Lipovetsky (2006) e Han (2017) definem a sociedade narcisista frente ao seu reflexo no espelho, desconsiderando a existência do outro. Essas concepções podem ser discutidas na obra de Valeska Soares, dona de vasta produção artística pautada pelo uso do espelho e seus reflexos, apresenta a obra Folly que é analisada com profundidade nesta reflexão (e neste Capítulo em especial).

Assim sendo, os três capítulos não são elementos isolados. Eles se intercalam naturalmente em conexão. Entre as oito obras levantadas pela pesquisa, decide-se focar a análise em apenas uma, pontuando ocasionalmente alguns momentos em que essas dialogam. A partir dessa concepção de encontros e desencontros se estabelece a relação com o pensamento de Merleau-Ponty (2006) que auxilia no entendimento sobre o processo de criação de Valeska Soares, no qual criar é destruir. Nesse contexto, transcender significa transformar o dado em outra coisa e, para isso, ele terá que ser destruído. O Folly é flutuante, como os dançarinos que estão no seu interior. A instalação cria diálogos entre a obra e seu espaço, expandindo limites espaciais e destruindo os suportes na arte.

Após todas essas considerações, ressalte-se que as questões centrais da presente pesquisar são: qual a importância do recurso espelho e o espelho d'água nos jardins de Inhotim e no fazer artístico contemporâneo para Valeska Soares? Quais são as conexões, diálogos e congruências estabelecidas através do artifício “espelho"? Qual é a questão (problema) tratada pela artista no percurso construído pelo artifício especular em Inhotim? Adjacente às indagações, este estudo fomenta estudos bibliográficos a respeito de Inhotim - que conta com poucas referências. Esta pesquisa pretende, sobretudo, dar início a um estudo que estabeleça conexões entre os reflexos especulares/natureza/arte contemporânea/visitante. 


\section{Capítulo 1 Espelhos em foco}

\subsection{Seus reflexos}

Este capítulo trata de algumas considerações sobre o uso do espelho ${ }^{3}$, da antiguidade até os tempos atuais, estabelecendo pontos importantes para a compreensão do tema e, acima de tudo, das questões que envolvem o espelho e seus reflexos em Inhotim. O uso do espelho no cotidiano é bem comum; ele é fonte de inquietações para muitos. Na História, nota-se uma aura de mistério no emprego do espelho (um tanto entre o revelar e ocultar a seu capricho suas distintas faces de quem reflete no espelho) esse aspecto sugere que há algo escondido dentro de suas bordas.

Nesta narrativa da história da arte por intermédio do uso do espelho, tem-se como primeiro exercício de análise o exemplo de um afresco que se encontra em Pompeia, desde o ano 60 d.C., na Vila dos Mistérios (Figura 1). Refere-se à festa de Dionísio, o deus metamorfose que muitas vezes é representado como um cabrito ou como uma criança, com o intuito de fugir da ira da deusa Hera - sempre preocupada com os inúmeros relacionamentos extraconjugais de seu marido Zeus (GRIMAL, 2000, p.221-222). O afresco é representado por três pessoas numa celebração de casamento: um homem maduro sentado está com uma tigela, um segundo personagem inclina-se para tentar ver o que existe dentro dela. E um terceiro aparece por trás do jovem que observa dentro da tigela, segurando uma máscara de teatro. A cena descreve uma prática de adivinhação do futuro através do reflexo da água ou do vinho, uma prática muito difundida na antiguidade. No ritual dionisíaco se tomava muito vinho, onde a expressão latina In vino veritas que se traduz como "no vinho, verdade" é recorrente nos escritos romanos. Essa máxima sugere que a pessoa sob a influência do álcool é mais propensa a

\footnotetext{
3 A palavra espelho tem origem no latim speculum, vinda de specere que significa "olhar". Possivelmente, a superfície da água inspirou a fabricação do primeiro espelho. São descobertos nos despojos da civilização badariana (junto ao Rio Nilo) espelhos de cobre, deixados pelo homem primitivo no século $\mathrm{V}$ a.C. Mais tarde, constroem-se espelhos de prata polida que é boa refletora, mas escurece com a atmosfera e precisa ser limpa e trabalhada frequentemente. De acordo com as técnicas de produção, a superfície do espelho é a primeira a ser talhada e polida com pedras de moagem grossa e fina, areia, argila e água. O esforço para produzir um espelho com uma esfera de obsidiana é estimado em oito horas. Espelhos antigos egípcios são fabricados de bronze polido e placas de cobre. Esses espelhos têm forma arredondada e um cabo geralmente feito de um material diferente, sendo alguns desses cabos ricamente decorados. Os primeiros registros escritos sobre espelhos metálicos estão na Bíblia, em Êxodo 38.8: "E ele fez a pia de cobre com a sua base de bronze, dos espelhos das mulheres que serviam à porta da tenda da congregação". Espelhos etruscos e gregos muitas vezes são ricamente decorados na parte de trás com cenas figurativas. Espelhos da Grécia antiga, muitas vezes, têm uma alça, atuando como ponto de apoio. Disponível em: https://www.gramatica.net.br/origem-das-palavras/etimologia-de-espelho/. Acesso em 09 jun. 2018.
} 
falar sobre seus pensamentos e desejos ocultos. $\mathrm{O}$ ato de se ver no reflexo assim como ao tomar o vinho na tigela sugiram a busca da verdade das coisas.

Comum no século $\mathrm{I}$, o rito dionisíaco associa o vinho às paixões humanas e à luxúria. O afresco sugere essa realidade: o personagem que segura a tigela é conhecido como um personagem da sátira romana, da comédia e dos excessos carnais humanos. No rito, o devoto vive a bebedeira como algo que aguça os sentidos. Os efeitos do vinho alteram as percepções humanas, facilitando o juízo do indivíduo sobre a alteridade, ou seja, possibilitando o contato com a figura do outro, ou, ainda, emerge o aspecto dual. $\mathrm{O}$ indivíduo experimenta emoções extremadas como impulsos: instintos selvagens em oposição às ações civilizadas, além de consciência sobre as diferenças entre o homem e a mulher, o deus e o homem compondo assim essa natureza dual. Nesse turbilhão de sentimentos, os reflexos do espelho d’água (ou do vinho da tigela do sátiro) e o estado de embriagues convidam os espectadores a especular o próprio futuro que perpassa a janela/portal, representando quem sabe a verdade que está dentro ou fora de cada um que a contempla.

Sob esse contexto, a presente pesquisa inicia trazendo a seguinte questão: que tipo de relação os gregos e romanos têm com as suas imagens refletidas? Para os gregos, no tempo de Homero, a representação de um rosto (a identidade visível da cabeça, a casa da alma da pessoa) possui aspecto intrinsecamente mágico. Para refrear o seu poder, a arte grega primitiva representa o rosto geralmente de perfil, para que seu olhar não atinja o espectador. Em geral, quando o rosto é representado em plena visão frontal - como em máscaras trágicas do teatro, conhecidas como gorgoêion - o objetivo é assustar o espectador, bem como proteger quem a veste (GRIMAL, 2000, p. 187). Aqui se remete à Górgona mítica, ou a Medusa, que no mito grego, é morta por Perseu. O herói para evitar olhá-la, serve-se de seu escudo polido, como espelho e, assim, não receia o olhar terrível que petrifica de horror (GREEN, 1994). As máscaras não só retratam um deus ou uma pessoa, na verdade, elas representam a "outra encarnação", o duplo daquele deus ou pessoa e são tratadas como tal. Como supõe num dos fragmentos da peça de Ésquilo, localizado no fragmento 1, Um dos personagens, segurando uma máscara de si mesmo, diz: "olhe e veja se esta imagem poderia ser parecida comigo, esta semelhança engenhosa: falta-lhe apenas uma voz [...]”. (Ishtmiastase, 5.21).

Platão refere-se às imagens espelhadas como: "criações falsas", pois o reflexo no espelho não tem a realidade tangível, sensível, na qual pode ser tocável, ou seja, definido como algo que pode ser percebido e entendido. "Se você decidir pegar um 
espelho e carregá-lo por toda parte" diz Sócrates a Platão ; "vai produzir rapidamente o sol e todos os seres no céu e produzir rapidamente a terra, a si mesmo, os outros animais, instrumentos, plantas e outro objetos [...]." "Sim", responde o seu companheiro, "a aparência deles, mas não a realidade e a verdade." PLATÃO, República, X, 596d-e).

A imagem não é apenas a semelhança do verdadeiro; não há verdade absoluta, ela apenas gera uma imagem inferior, sem essência, pois essa produz uma mimesis (conceito grego que significa imitação, ação de imitar, de representação e de figurar) (CHAUÍ, 2002, p. 506). E, portanto, ela não é verdadeira.

O mundo sensível explica-se por meio de imagens e o incorpóreo somente pelo raciocínio. Em A República, Platão compara os dois mundos. Para ele, o mundo das ideias ou o topos uranos é onde nada passa e muda; onde vivem as almas antes de encarnar, em outras palavras, o lugar celeste. No mesmo livro, ele descreve uma caverna escura onde existem pessoas presas. Essas pessoas estão acorrentadas de costas para saída e diante da entrada dessa caverna passam objetos e pessoas iluminados pelo sol. Esses homens acorrentados veem os reflexos na parede. Veem apenas sombras projetadas. Eles contemplam o mundo através de uma tela. A nossa visão humana capta o mundo inteligível como essa tela no fundo da caverna; só se veem sombras efêmeras, transitórias, imperfeitas, vultos e simulacros da realidade do mundo inteligível que teoricamente está do lado de fora da caverna. O próprio sentido da palavra ideia é um neologismo criado por Platão; ele a forma com a raiz de um verbo grego que significa "ver". De modo que "ideia", realmente, significa visão, intuição intelectual.

Após as breves reflexões sobre a visão do mundo inteligível e o visível, retomese a análise do afresco. A imagem na Figura 1 consiste num quadro pequeno com a presença de três homens. Um deles talvez esteja praticando a lecanomância ou a catoptromancia $^{4}$, uma prática usual entre os romanos, que consiste em adivinhar o futuro através do reflexo numa superfície líquida. Observa-se no canto direito da parede

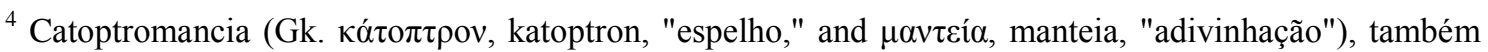
conhecida como captromancia ou enoptromancia, é adivinhação usando um espelho. Pausânias, um viajante da Grécia antiga, a descreve: "antes do Templo de Ceres, em Patras, havia uma fonte, separada do templo por uma parede, e havia um oráculo, muito verdadeiro, não para todos os eventos, mas apenas para os doentes. A pessoa doente baixou um espelho, suspensa por um fio até que sua base tocou a superfície da água, tendo primeiro rezado à deusa e oferecido incenso. Então, olhando no espelho, ele viu o presságio de morte ou recuperação, de acordo com a aparência do rosto fresco e saudável, ou de um aspecto horrível". Em Roma, os sacerdotes que usam a catoptromancia são chamados specularii. Disponível em: < https://pt.wikipedia.org/wiki/Captromancia>. Acesso em 26 abr. 2019.
} 
mais distante a figura sentada do sátiro Sileno que ergue uma tigela para que um jovem rapaz beba o líquido. Atrás deles, um jovem levanta uma máscara teatral, de modo que, ao examinar a tigela, talvez para ver seu futuro nas feições espelhadas, a imagem refletida não seja de sua própria face, mas a da máscara barbuda.

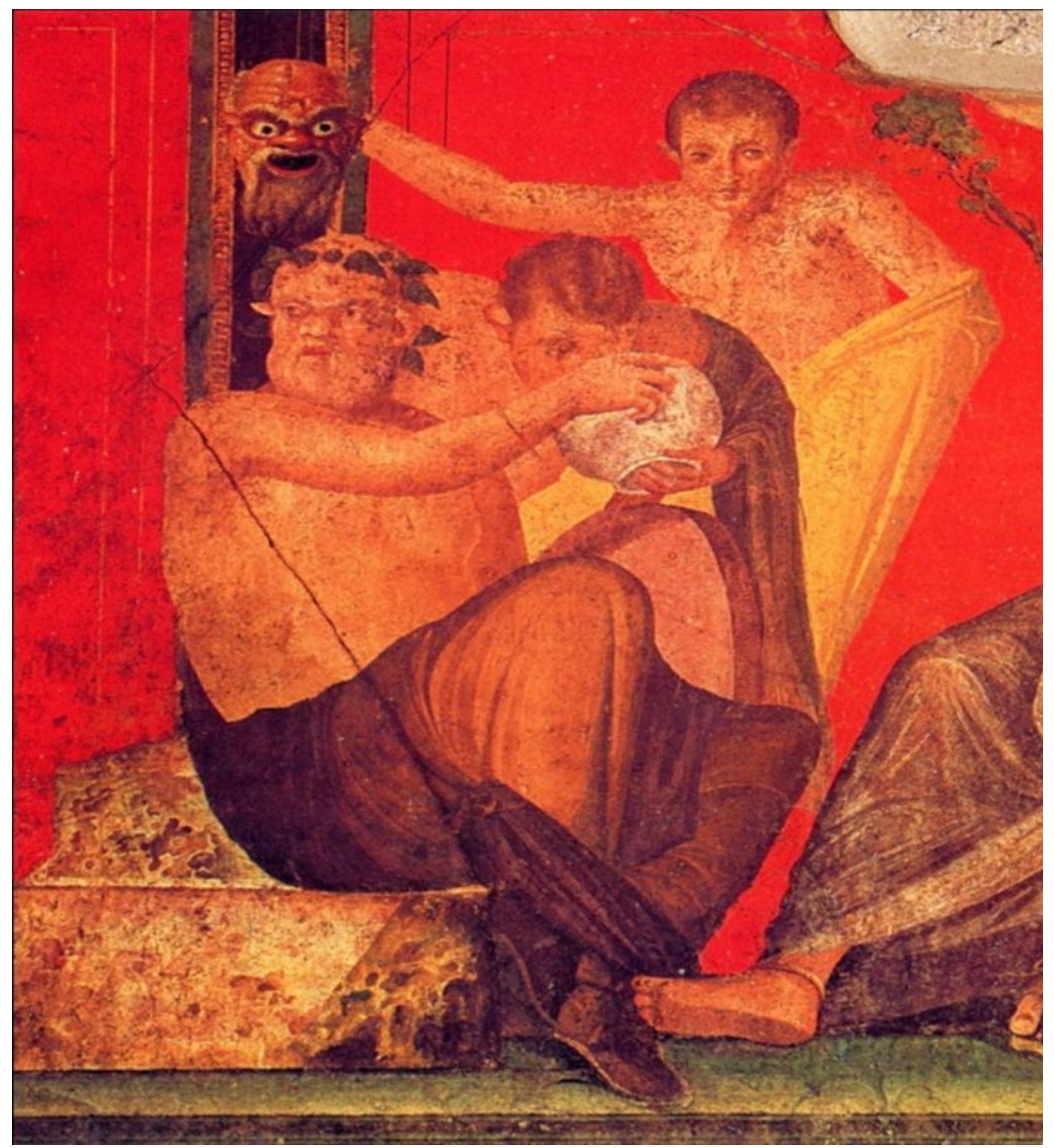

Figura 1. Artista desconhecido, Pompeia, Itália. Detalhe Vila dos Mistérios, 60-50 a.C. Técnica Afresco 1,62 de altura.

Fonte: http://viagemitalia.com/category/arqueologia-romana/page/3/. Acesso em: 05 de jun. 2018.

Essa ideia de ver a máscara e não a própria imagem no reflexo dentro da tigela mostra que a imagem devolvida, talvez não seja a real, mas outra face, ou, ainda, a sombra do que é a verdade. De fato, não se sabe se é verdadeira ou falsa, mas não é a face que se apresenta em no mundo exterior. Essa imagem refletida da máscara no líquido de dentro da tigela representa o mundo sensível, onde as coisas se mostram imperfeitas e falsas. Uma aparição do duplo: duas imagens que derivam de um mesmo sujeito imperfeitamente ajustável, nas quais o rapaz que se vê, contempla sua autoimagem de forma grotesca e inferior, representando assim uma imagem cheia de 
vício, um engodo. Retornando ao conceito de Sócrates (República X, 597d) de Platão, sobre o mito da caverna, esse afresco expressa uma mimese. Sabe-se que Sileno, o poeta, existe, porém, sua representação também é uma imitação da natureza, uma vez que, de acordo com Sócrates, o poeta é considerado como "um imitador", afastado três vezes da verdade (o poeta cria a "forma poética"; as duas primeiras são a "forma ideal" e a "forma natural"). Ainda de maneira tangível, o rapaz que olha seu rosto, que não é seu rosto, mas sim uma máscara refletida no líquido da tigela, demonstra de modo coesivo a concepção de Platão. Na verdade, o que se vê são sombras, imagens disformes daquilo que existe no mundo inteligível.

A ideia de se ver disformemente provoca estranhamento e terror. Se a imagem for tratada como a transformação do período da vida, nota-se a mutação: a idade, a experiência, as emoções, os acasos e as mudanças de luz alteram os traços faciais de modo que um reflexo especular pode constantemente surpreender, produzir simulacrum da natureza e da identidade. Não existe um rosto presente: quando se pensa ter captado as feições num reflexo, elas já se modificam em alguma outra coisa, empurrando o observador para o futuro. Essa mutação é transgressora da teoria de Platão, visto que as coisas do mundo inteligível são unas e fixas e produzem virtude. Para Platão, o mundo das ideias ou o inteligível não se transforma - tudo é imutável.

A imagem do afresco em sua totalidade é a imagem que o espectador não vê. $O$ reflexo dentro da tigela produz agon (termo grego que significa luta, perigo, temor, ansiedade e angústia). Ela também designa qualquer assembleia ligada aos jogos e conflitos naquele que a contempla. A luz faz que o olho veja da melhor maneira possível e que sejam vistos os objetos sensíveis, mas o sol não é visto, mas a sua causa e, é visto por ela mesma. O mesmo se diz da progênie do Bem (...) isto é, na esfera intelectiva, ela é para as inteligências e os inteligíveis, o que o sol é para a esfera visual, para os olhos e os visíveis.

Mas como? Sabe-se que quando os olhos se voltam para os objetos
iluminados pela claridade noturna, ofuscam-se e aparecem quase cegos (...).
Porém, quando se voltam para os objetos iluminados pelo sol, vê-se
claramente. O mesmo acontece com a alma: quando se fixa no que está
iluminado pela verdade e o ser, compreende e conhece, e surge dotada de
inteligência; mas quando se dirige o seu olhar para objetos envoltos em
trevas, para o que nasce e morre, não sabe o que pensar e ofusca-se, mudando
constantemente de ideia. E parece privada de inteligência. Parece. - Ora, o
que fornece verdade ao conhecido e capacidade ao cognoscente, deves dizer
que é a ideia do Bem (...); e como no caso precedente era justo considerar a
luz e a vista como semelhantes ao sol, mas não podia com justiça considerá-
las a ambas semelhantes ao Bem, mas não é correto que alguma delas seja o
Bem; mas é necessário emprestar maior valor à natureza do Bem (...). E 
como? - O sol, dirás (creio), não dá às coisas visíveis somente para a possibilidade de serem vistas, mas também o seu nascimento. $\mathrm{O}$ seu crescimento e a alimentação ainda sem ser ele o nascimento etc... E também os cognoscíveis não só devem ao Bem serem conhecidos, mas também o ser e a essência, sem que o bem seja a essência, antes, permanecendo, superior à essência, por dignidade e potência (PLATÃO, República VI, 508a ).

Então, refere-se à visão do afresco como uma visão noturna. Não se sabe, com efeito, o que ela representa. São muitas as interpretações e tem-se em mãos apenas um detalhe do total. O rapaz, ao ver seu reflexo transfigurado refletido no líquido da tigela, é despertado para uma repulsa perante a aparição do duplo, mesmo se tratando de um reflexo onírico.

Na esfera do pensamento, a ideia do Bem é a mais afastada, e é necessário esforço para vê-la, mas uma vez lobrigada, deve compreender-se que ela é, para todos, causa de todas as coisas justas e belas, e no visível gera a luz e o seu autor, e no inteligível ela mesma é autora e produtora de verdade e inteligência (PLATÃO, República VII, 517a).

O espelho é um sofisma, assim como Dionísio é o deus do duplo, das metamorfoses, dos opostos, não passa de uma sombra, de uma embriaguez noturna. Observam-se os olhares que não se cruzam, os três personagens não se entreolham, mas há um elemento que se destaca: a máscara nas mãos do jovem que auxilia o Sátiro na "brincadeira" de iludir o outro rapaz que tenta ver seu futuro através da água na tigela. Ela sim, a máscara, é a única que olha diretamente e frontalmente para o espectador. A máscara encara e petrifica todos que a observam. Amedrontadora, ela desafia os espectadores a decifrarem seus mistérios em meio às ilusões e fantasias dionisíacas.

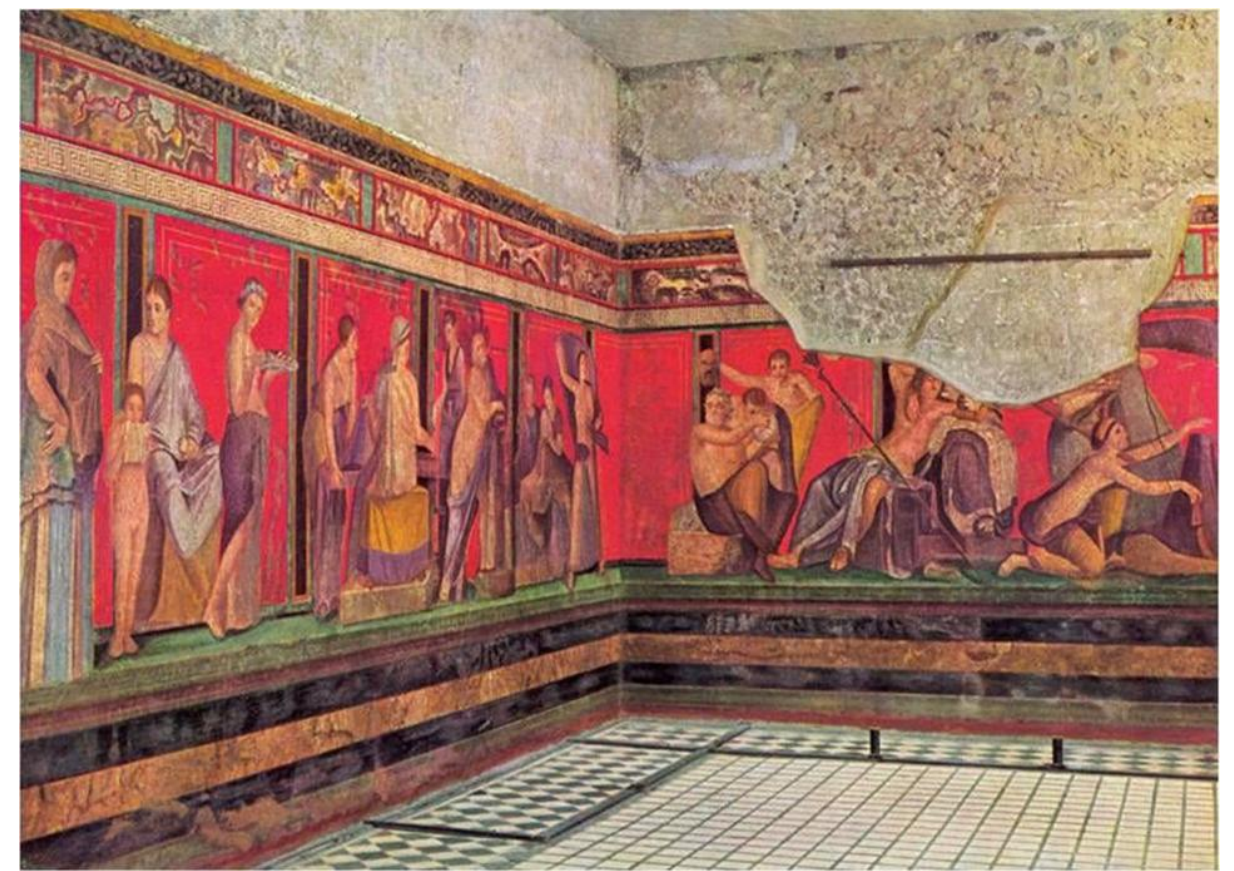

Figura 2. Artista desconhecido, Pompeia, Itália. Detalhe Vila dos Mistérios, 60 a.C.-50 a.C. Técnica Afresco, 1,62 de altura.

Fonte: http://artenarede.com.br/blog/wp-content/uploads/2016/01/Mural1.jpg. Acesso em: 05 jun. 2018. 
A imagem do afresco (Figura 2) traz a representação do cotidiano em Pompeia, onde os ritos, o teatro, o vinho e a adivinhação são temas recorrentes. Não se sabe ao certo o que o artista tem em mente quando escolhe o poeta sátiro para ilustrar esse rito. A tigela, por ser redonda, pode ser vista como uma janela, assim como o espelho pode ser um portal para outros universos, outros entendimentos e saberes para quem observa seu interior. O conteúdo da tigela que o poeta Sileno traz em suas mãos pode reportar à imagem do rito dionisíaco, uma vez que coloca a presença do vinho como um dispositivo desencadeador da verdade transformadora das identidades ambíguas, das alucinações, ilusões, medos e simulacros da própria humanidade.

No Renascimento, Leonardo da Vinci (1452-1519) usa o compasso, o esquadro e os espelhos em seus projetos. Ele segue o modelo das formas do corpo em diversos estudos e está preocupado em transmitir suas descobertas. Os princípios de seu Tratado de Pintura, que nunca fora terminado, chegam às ideias ligadas à irradiação, à ótica, aos óculos (lentes) e à reflexão da luz em espelhos parabólicos. Provavelmente, Da Vinci utiliza o jogo de espelhos, são três ao menos: um de frente, um de três quartos e um de costas. O pintor desenha uma cabine de plano octogonal, coberta de espelhos (Figura 3), sobre a qual se coloca no interior para ver em cada direção uma infinidade de vezes. Esse formato octagonal se vê presente na obra Folly de Valeska Soares que será analisada no capítulo 3 desta pesquisa.

Para da Vinci, conjunto de espelhos permite que a pessoa se veja em três quartos de frente, sem encontrar seu olhar, como no autorretrato de Turim. O artista ainda discute as afinidades das representações bidimensionais, tendo o espelho como um mestre fiel para investigar os defeitos da pintura e como aparecem os objetos em um plano:

\footnotetext{
Pintura e espelho conhecem uma só superfície e [suas imagens são] impalpáveis, por quanto àquele que se mostra redondo e destacado não pode ser abarcado com as mãos, pois se vê que o espelho por meio de linhas, sombras e luzes apresenta os corpos como um relevo, tua pintura, que dispõe de cores luzes e sombras mais intensas que as do espelho parecem uma cena natural refletida em um grande espelho (DA VINCI, 1982, p. 347).
}

Nessa cabine de espelhos, Da Vinci faz o balanço de sua vida. À ponta do lápis, o pintor reproduz as rugas, as pregas e os decaimentos da carne. Ele se procura, se interroga e reflete-se. Desenhar em frente ao espelho é uma maneira de compreender, de investigação científica e filosófica. A maestria do espelho para comprovar se suas pinturas, desenhos correspondem exatamente às proporções reais, comparando a 
imagem refletida com a obra. Usando um espelho plano como um mestre, frente a frente, o reflexo propaga as infinitas imagens dos corpos. Para ele, a pintura deve parecer uma coisa natural vista num espelho.

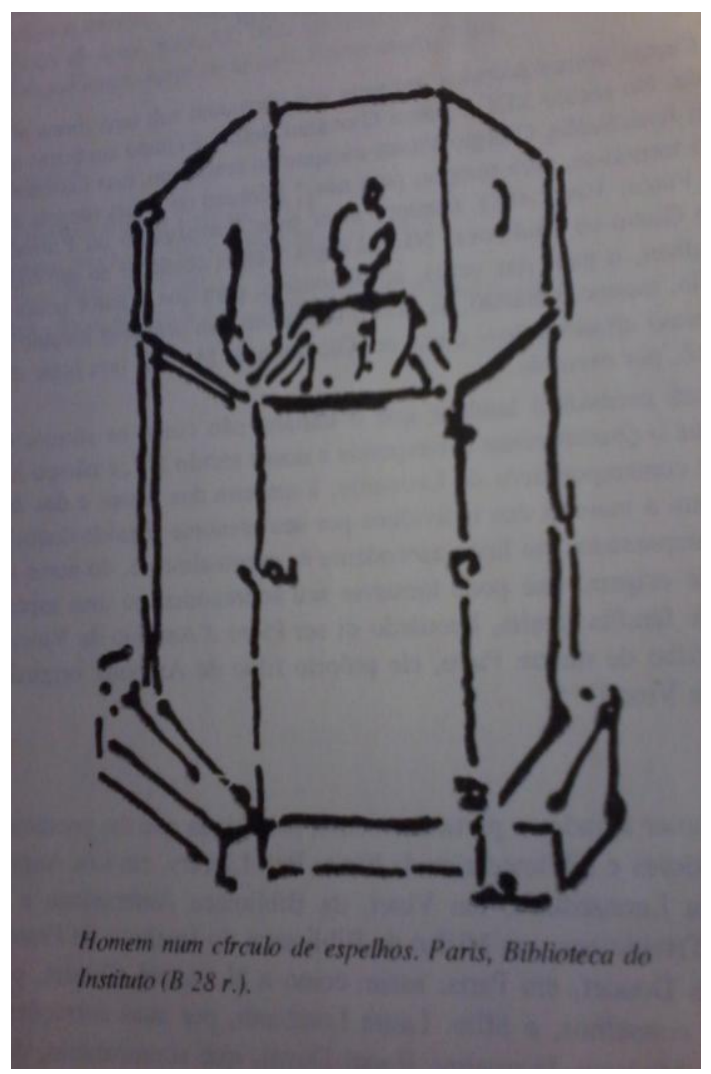

Figura 3. Câmera especular. Fonte: (BRAMLY, 1989).

Na Idade Média, o imaginário e o simbólico especular se cruzam principalmente nas artes, representando significados populares, tais como: "o espejo es el verdadeiro culo del diablo" (ZAFRA, 2000, p. 297). Nesse sentido, a obra de Hieronymus Bosch (c. 1450 - 1516), conhecida como O jardim das delícias (1480-1490) é um exemplo bastante conhecido. Nela, existe um detalhe: uma mulher nua, sentada com um sapo entre os peitos (Figura 4). Ela se vê refletida num espelho nas nádegas de um demônio. O espelho se transmuta em testemunha da vida e da morte. O espelho devolve a imagem dos mortos e se converte em delator, pois o espelho reflete o passado, delata o presente que muitas vezes se nega. $\mathrm{O}$ espelho pode ser considerado uma espécie de portal do inferno, no qual os demônios transitam pelo mundo e submundo. $\mathrm{O}$ espelho recolhe o passo do tempo que não se recupera do destronamento produzido por um presente ou, ainda, uma realidade que se converte em passado. O espelho é o protagonista principal 
de histórias, lendas urbanas e obras de arte. Ele nos conta outras coisas, tais como: medos, deformidades mescladas com desencanto, multiplicidade e desafios.

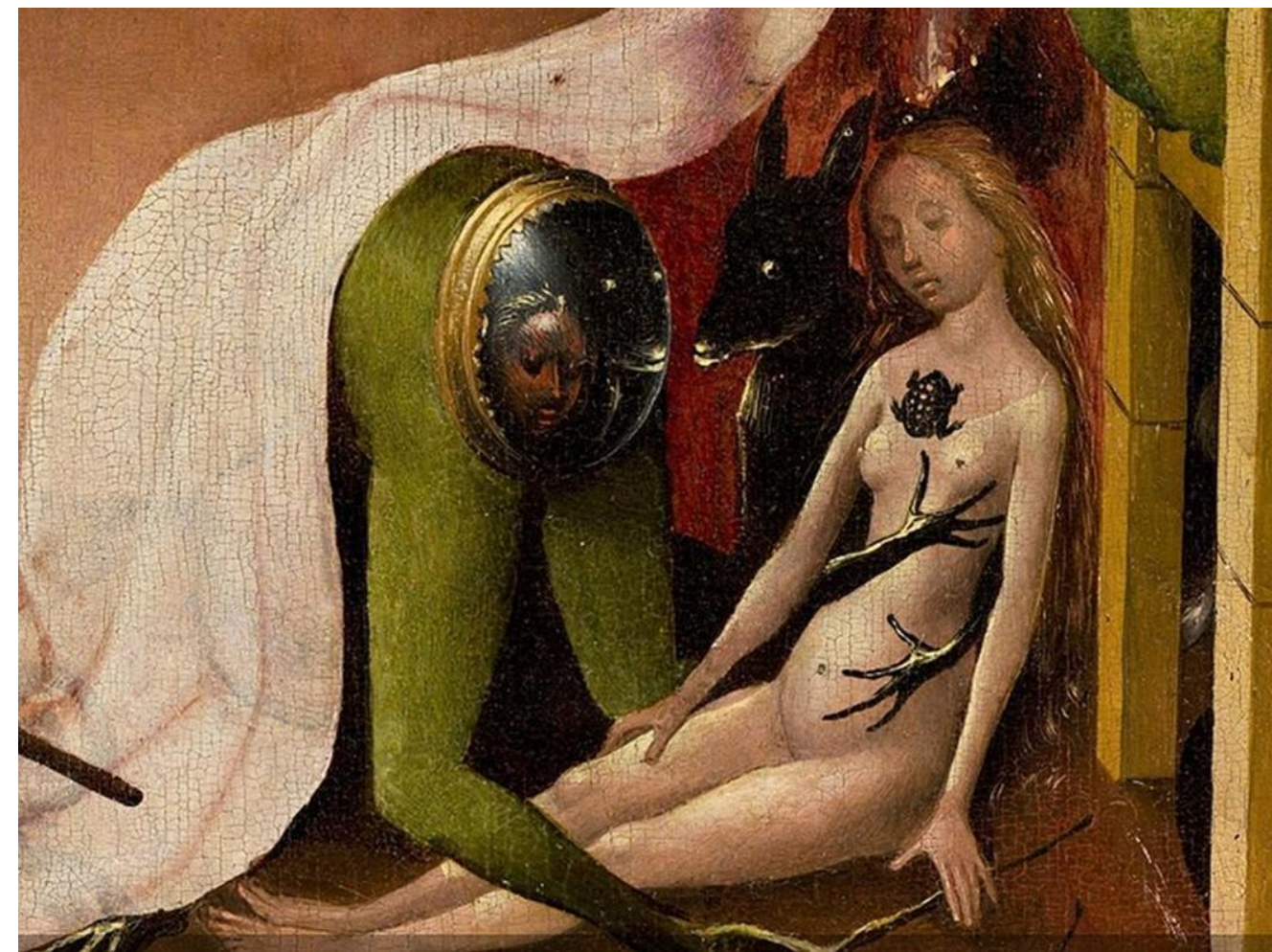

Figura 4. Hieronymus Bosch. Jardim das delícias (detalhe), óleo sobre tábua, 1480-1490. Museu do Prado, Madri.

Fonte: https:/www.museodelprado.es/coleccion/obra-de-arte/triptico-del-jardin-de-lasdelicias/02388242-6d6a-4e9e-a992-e1311eab3609. Acesso em: 28 jun. 2018.

Segundo Cacciari (2000), até no maneirismo existe uma tradição filosófica que faz distinção entre o espelho enganador que distorce a realidade e o espelho sem mácula que reflete os objetos e as coisas como são na realidade, como registro documental. Dentro dessa segunda visão, Jan van Eyck (1390-1441), ao pintar a si próprio, na tela $O$ casal Arnolfini (Figura 5), uma das obras mais famosas do Renascimento Flamengo, tem como intenção deixar exposto o seu próprio olhar ao olhar do espectador. Com precisão, o pintor representa a realidade através de um espelho convexo.

Ao retornar ao detalhe da obra de Eyck, é possível pensar no significado do espelho como um enigma e como a inclusão do espectador na obra. Van Eyck se vale dessa técnica e se coloca no ponto de fuga, onde reflete e se reflete, observando a cena que ele está a pintar. De acordo Conte (2013, p.61), nesse ponto, aparece a seguinte questão: olhar versus ser olhado. Nesse ponto de vista, na imagem do espelho cujo pintor se olha, vê-se o casal de costas e na borda do espelho, existem citações 
encrustadas da Paixão de Cristo. Na parede ao centro, abaixo do lustre a assinatura: "Johannes de eyck fuit hic" (Jan van Eyck esteve aqui).

Aqui, na verdade, não há paralelo com os mestres do início da Renascença na Itália, que nunca abandonaram as tradições da arte grega e romana. Lembramos que os antigos 'idealizaram' a figura humana em obras como a Vênus de Milo ou o Apolo de Belvedere. Jan van Eyck não teria nada disso. Ele deve ter posto modelos nus à sua frente e pintou-os tão fielmente, que gerações mais tardias ficaram um tanto chocadas com tanta honestidade. Não que o artista não tenha olhos para a beleza (GOMBRICH, 2006, p. 176).

Segundo Gombrich (2006), a assinatura adquire a função de testemunho de um ato solene, pois a pintura integra a cerimônia matrimonial. A assinatura é, acima de tudo, um ato de eternização de sua existência, autoria, status social (pois, o ato de saber escrever corresponde a uma classe social abastada). Além disso, espelho/vidro é caríssimo e é um importante símbolo de riqueza (VIGNA, 2009). O artista espelha-se na assinatura. $\mathrm{O}$ espelho reproduz o ambiente e a cena no sentido inverso ao olhar do espectador. $\mathrm{O}$ artista pinta seu autorretrato enquanto pinta o retrato do casal pelas costas refletidas no espelho. Van Eyck legitima a cerimônia do casal. Ele testemunha três vezes o casamento, como pintor, como testemunha ocular e com sua assinatura na parede. Sua identidade e autoria diante do espectador é um ato de eternizar seu feito na sua própria obra. Ele se espelha na imagem do espelho e também através da própria assinatura.
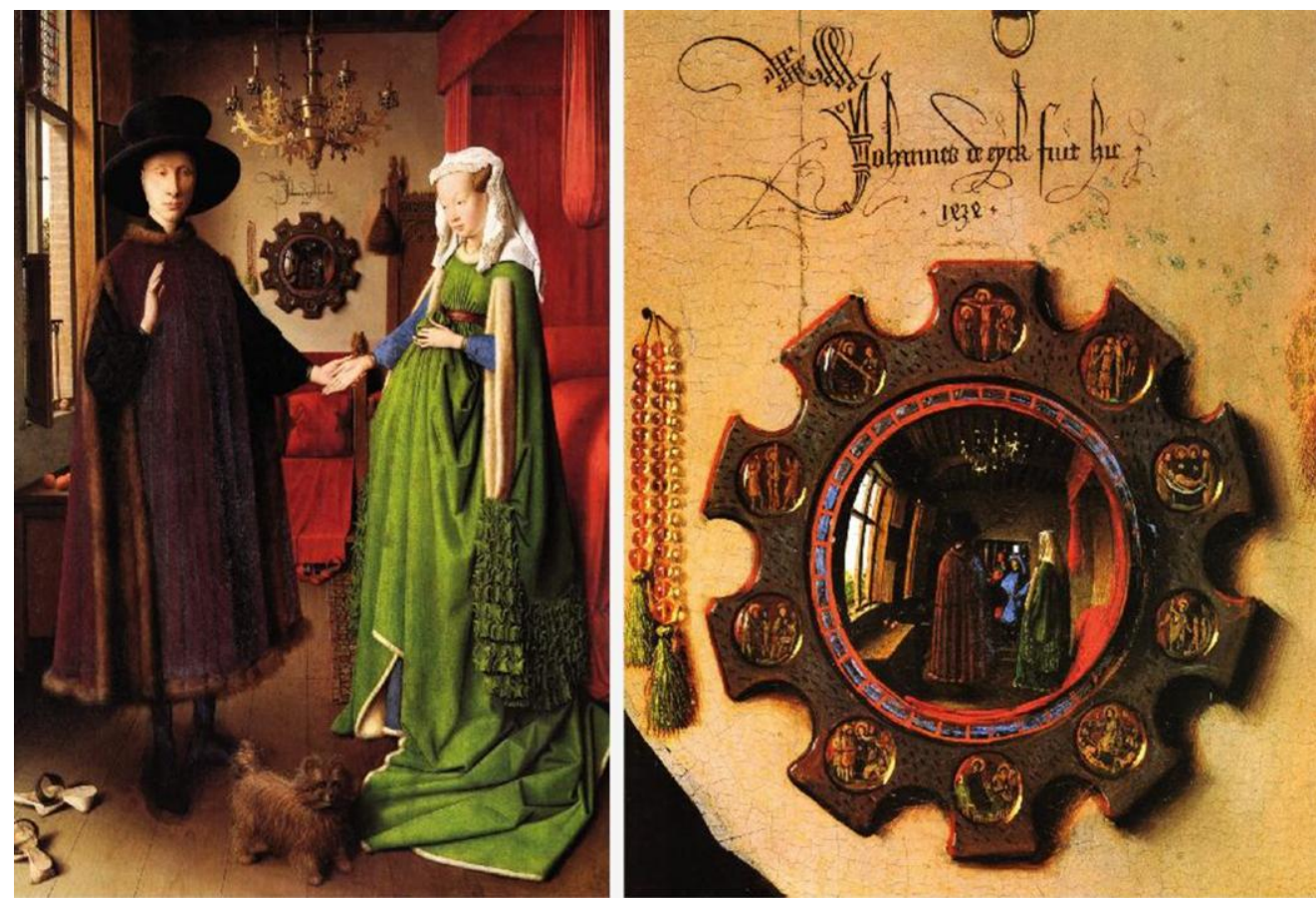

Figura 5. Jan Van Eyck, $O$ casal Arnolfini, óleo sobre tábua, 1434. National Gallery Londres.

Fonte:http://storiadiunospecchio.blogspot.com.br/2012/10/le-immagini-della-cosapittura.html Acesso em: 01 dez.2017. 
Diego Velásquez (1599-1660) é um dos mais conhecidos pintores a se render ao recurso do espelho, não com o intuito de enganar o olho, mas para criar uma armadilha para o olhar, ser flagrado no ato de olhar (Figura 6). Na obra As meninas, 1656, o olhar do pintor de dentro da tela observa o espaço exterior; todo o espaço é ocupado por quem observa (o espectador) a tela. Através do seu olhar, o observador supõe o que Velásquez irá pintar: a cena e os modelos que está pintando. Seu olhar atravessa o espaço da representação de maneira que o pintor observa o espectador no ato da pintura, como se fosse o seu modelo naquele momento (CONTE, 2013). Esse cruzamento de olhares provoca a inclusão do sujeito no campo amoroso. Esse fenômeno de estratégia ótica atravessa o espaço da representação para dar espaço o real, onde o espectador espreita, mas também é espreitado pelo pintor de dentro da tela, como se o espectador fosse um modelo naquele momento. Velásquez é o principal artista da corte do rei Felipe IV da Espanha e um dos mais relevantes do barroco (GOMBRICH, 2001, p.406). Em suas obras, coloca-se o problema da representação. Não é à toa que uma de suas telas é escolhida para integrar as primeiras páginas de As palavras e as coisas, em que Foucault discute justamente o parâmetro de representação na Idade Clássica.

De fato, a beleza das obras de maturidade de Velásquez se estabelece de tal forma no efeito da pincelada e na harmonia delicada das cores que as ilustrações dão somente uma fraca ideia dos originais. [...] Por causa de efeitos desta ordem, os pintores impressionistas admiravam Velásquez mais que qualquer outro mestre antigo (GOMBRICH, 2001, p.408-410).

$\mathrm{Na}$ infinidade de detalhes da obra, que vai da menor pincelada do vestido da infanta até o jogo complexo de olhares entre as personagens da composição, o espelho desempenha um papel crucial na construção dos efeitos de sentido. $\mathrm{Na}$ análise dessa tela, realizada por Foucault (2006), o espelho não passa, obviamente, despercebido. Aqui alguns dos trechos em que o autor menciona sobre o uso do espelho.

Mas eis que, entre todas essas telas suspensas, uma dentre elas brilha com uma luminosidade singular [...].

Entre todos esses elementos destinados a oferecer representações, mas que as contestam, ocultam-nas, as escamoteiam por sua posição ou por sua distância, aquele é o único que funciona com toda honestidade e que mostra o que deve mostrar [...]. Em vez de girar em torno dos objetos visíveis, esse espelho atravessa todo o campo da representação, negligenciando o que ele poderia ali captar, e restitui a visibilidade ao que permanece fora de qualquer olhar. [...] O espelho, mostrando, mais além das paredes do ateliê, o que se 
passa na frente do quadro faz oscilar, em sua dimensão sagital, o interior e o exterior (FOUCAULT, 2006 p. 198-203).

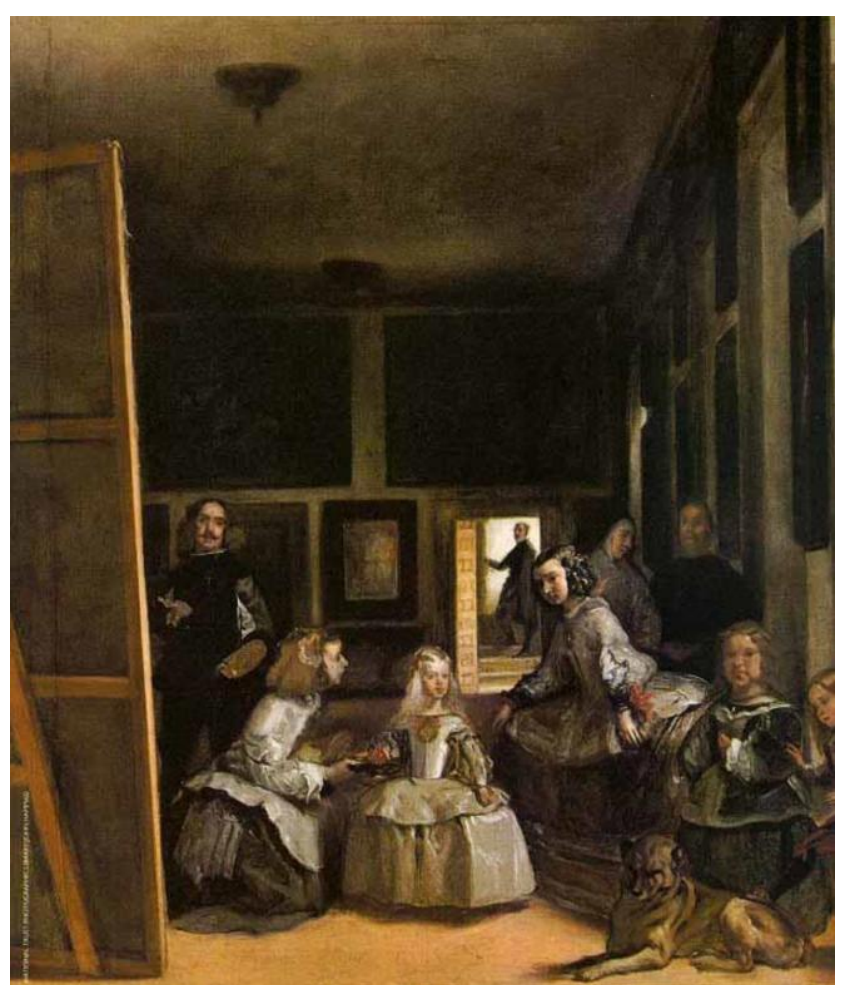

Figura 6. Diego Velásquez. As meninas, óleo sobre tela, 1656. Museu do Prado, Madri.

Fonte: https://pt.wikipedia.org/wiki/As_Meninas_(Vel\%C3\%A1zquez). Acesso em: 02 dez. 2017.

As obras de Eyck e Velásquez buscam uma relação eidética, visto que se dá o mesmo fenômeno da ilusão de ótica. As pinturas contêm o que se vê e o que não se vê, num jogo de espelho: quadro dentro do quadro; imagens de imagens; o rompimento de barreiras entre o espaço da representação e o do espectador; memória e, principalmente a inclusão do espectador no campo da representação. Assim sendo, o espectador se identifica com o ponto em que normalmente se colocam os artistas na realização da obra. O reflexo assume a postura do pintor que está de frente à obra em processo.

Nessa direção, observa-se outros artistas que tratam com a inclusão do olhar do espectador no campo da representação, Édouard Manet (1832-1883) na tela Um bar em Folies-Bergère (Figura 7). Há uma combinação de retrato, natureza-morta e cena de cotidiano. Nela, o espelho é o elemento do enunciado visual que mais contribui para o efeito de "estranhamento". 


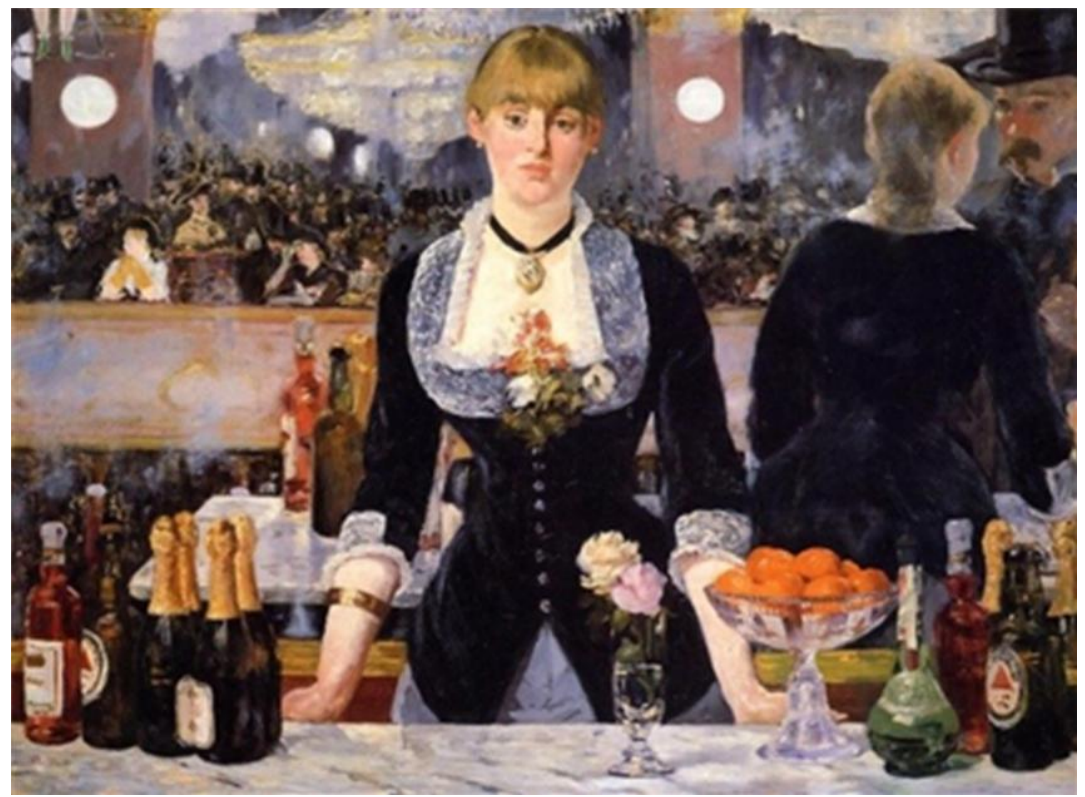

Figura 7. Édouard Manet. Um bar em Folies-Bergère, óleo sobre tela, $96 \mathrm{x}$ $130 \mathrm{~cm}$, 1881-1882. Courtauld Institute Galleries. Fonte: https://pt.wikipedia.org/w/index.php?title=Um_Bar_no_FoliesBerg\%C3\%A8r e\&oldid=53727979. Acesso em: 02 dez. 2017.

O espelho atua como um nó de sentido, para onde convergem os outros elementos visuais no momento da interpretação da pintura. Nesse sentido, para que o reflexo fosse visto onde está, segundo os princípios ópticos, o pintor e o espectador estariam na extrema esquerda da tela. Onde o pintor se encontra, um reflexo seria gerado justamente atrás do corpo da mulher, isto porque o espelho não está em posição oblíqua. Para Foucault (2004, p.45), “o pintor ocupa então - e o espectador é convidado depois dele a ocupar - sucessivamente, ou ainda simultaneamente, dois lugares incompatíveis: um aqui e outro ali”. Assim sendo, observam-se algumas incompatibilidades, tais como: a posição ambígua e simultânea do pintor e espectador e, a presença/ausência da personagem que conversa com a atendente, incidindo nos jogos de luz e no olhar descendente daquele que fala com ela, em contraposição ao olhar ascendente em direção à cena representada. Na tela, o espectador é convidado a deslocar-se em torno a fim de encontrar a posição que lhe é acordada. No entanto, essa posição não existe. É uma posição mista, aqui e lá simultaneamente. O olhar do público 
na obra pode se transpor e se revelar no espaço. $O$ ir e vir toma sentido: o jogo de olhares - entre as personagens, o pintor e o espectador, há um jogo de olhares.

\subsection{Momentos estéticos}

Este tópico aborda a junção entre arte e natureza, pensando o espelho d'água como meio dessa relação. Para essa missão, evoca-se o jardim japonês de Claude Monet (1840-1926) em Giverny (Figura 9), isto porque o presente estudo entende que o jardim francês e o jardim botânico de Inhotim têm muito em comum.

No projeto paisagístico de Inhotim, o percurso se estabelece através dos reflexos vindos das águas. Na travessia de reflexos, água, natureza e arte formassem as faces do espelho. Ressalte-se que esse projeto é realizado ao longo do tempo por uma equipe ${ }^{5}$. Seu paisagismo, isto é, a disposição do acervo botânico dentro da área de visitação, explora padrões estéticos num jogo e ir e vir entre a obra de arte e jardim. Ele remete em particular à transição entre o plano do desenho (ou a tela) e o espaço tridimensional de um jardim.

$\mathrm{Na}$ pintura ocidental, a perspectiva surge como ciência, "que faz parecer em relevo o que é plano e plano o que está em relevo", como confere Da Vinci (1934, p. 227). Nesse duplo sentido e conforme o Tratado da Pintura, três partes são observadas: a diminuição e distorção quantitativa dos corpos; a atenuação das cores e a diminuição das figuras e dos contornos em diferentes distâncias por causa da luz. Esse distanciamento do reflexo ou corpo refletido adquire significado pela cor azul opaco do ar. Assim, como afirma Da Vinci (1934), "as coisas mais distantes parecem azuladas, por causa da grande quantidade de ar que se encontra entre o olho e o objeto". Nesse ponto, recorda-se Claude Monet, artista impressionista, obstinado em reproduzir a luz natural e seus efeitos ao longo do dia em suas pinturas. Para tanto, ele lança mão da água e seus reflexos, formando um visual único semelhante ao que Da Vinci relata. Os reflexos do ar e das águas se transmutam em azul ou tons azulados, dependendo do ângulo da visão do espectador, bem como somado ao tempo espaço (jardim).

Nesse diálogo entre natureza e arte, nota-se a presença pictórica da tradição oriental nos jardins de Monet:

\footnotetext{
5 O paisagismo é desenvolvido por vários profissionais, entre eles, Pedro Nehring, que colabora desde a fundação do Instituto e é o principal paisagista. Luiz Carlos Orsini, responsável pelo projeto paisagístico de 25 hectares, entre 2000 e 2004, também é um nome de destaque. Disponível emhttps://www.inhotim.org.br/inhotim/jardim-botanico/paisagismo/ Acesso em: 09 abr. 2019.
} 
Essa visão pode ser considerada oriental, consegue equilibrar a visão ocidental através de um paralelismo entre água, paisagem e céu. Monet utilizava conscientemente em sua obra pictórica, elemento de concepção plástica oriental (MACHADO, 1986, p.16).

De fato, é possível encontrar paralelos conceituais entre o jardim botânico de Inhotim e Giverny? Talvez, essa pergunta possa ser elucidada por Roberto Burle Marx (1909-1994), o mais renomado paisagista brasileiro. Ele pode esclarecer sobre o processo poético paisagístico, inclusive com exemplos de jardins aos atribuídos a ele em Inhotim:

O jardim paisagístico, em suas formas originais, era feito como reflexo, e não como imitação da paisagem. O importante é compreender o ambiente para o qual o jardim é criado. Podemos aprender pelo estudo de outros jardins, como podemos e devemos aprender também do estudo da paisagem inerente. $\mathrm{O}$ objetivo deve ser sempre o de refletir a paisagem circundante, plantar no jardim as espécies que crescem na região, já adequadas ao solo e ao clima. $\mathrm{O}$ jardim deve pertencer, em espírito, ao lugar onde está situado, pois, por mais cuidadoso que tenha sido seu planejamento, nunca se apresentará perfeitamente bem se as plantas que o constituem não forem ecologicamente compatíveis. (MARX apud TABACOW, 2004, p. 62, grifos nossos).

Ainda em paralelo, é possível observar em ambos os processos paisagísticos a influência de outros jardins sustentados pelas noções de percepção e de consciência paisagística - ressalte-se que como Burle Marx, Monet é exímio observador da beleza. Ao ser questionado pelo amigo Clemenceau sobre qual o método seletivo por ele usado em seu trabalho diário, Monet responde: “observar tudo, por toda parte" (MONET apud MACHADO, 1986, p.17). Mencione-se ainda que o pintor queira ser comoventemente fiel ao que vê:

\footnotetext{
(...) eu exerço simplesmente meu esforço sobre um máximo de aparências, em estreitas relações com as realidades desconhecidas. Quando nós estamos no plano das aparências concordantes, não podemos estar bem longe da realidade ou, ao menos, do que nós podemos conhecer (...). Eu não faço mais que olhar o que me mostra o universo, a fim de dar testemunho através do meu pincel. (...) Isso será pouco? Seu erro é de querer reduzir o mundo à sua medida, enquanto que, crescendo seu conhecimento de você mesmo (...) sua mão na minha mão, ajudando-nos uns aos outros a olhar com atenção (MONET apud MACHADO, 1986, p. 17, 18).
}

Essa declaração de Monet, sobre seu ato de recriar a realidade à medida de si mesmo, harmonizando valores orientais e ocidentais, numa visão extremamente original, trata-se da percepção - algo subjetivo do sujeito que observa essa natureza. Observam-se ainda as interações entre as estampas japonesas (repetição, multiplicação, assim como os espelhos paralelos), a pintura chinesa e o jardim. Monet emprega uma paleta simples. Assinala-se, nesse ponto, que o pintor mistura cores com branco de 
chumbo $^{6}$, a fim de criar efeitos de reflexos luminosos como os espelhos d'água. O seu objetivo é a síntese, de tal forma absoluta, que nela está refletida uma visão universal.

Essa síntese se consuma no último período de sua vida, na série Ninfeias, 1883 ano em que o artista se muda com a família para Giverny, cidade a $75 \mathrm{~km}$ de Paris. Encantado com a natureza do local, o paisagista - como ele faz questão de se intitular cria dois espaços distintos: Clos Normand, o jardim de flores que cerca a propriedade, e o jardim d'água, onde fica o famoso lago de ninfeias cortado por uma ponte japonesa. Inspirada pelo jardim d'água, a série Nenúfares (ou, em francês, nymphéas) é composta por aproximadamente 280 pinturas a óleo - muitas dessas obras são realizadas quando o pintor já está sofrendo de cataratas. Entre a concepção do jardim e da série, Monet idealiza um conjunto decorativo no qual o espectador mergulha em impressões - o projeto Monet-Giverny-Ninfeias dura mais de 30 anos. Em Giverny (Figura 9), o colorido segue as estações e as diversas floradas. Não à toa, torna-se elã para as obras do pintor. E vem daí, a sensação de que visitar os jardins é como adentrar suas telas.

Na tela La Plage de Trouville, 1870, de Monet, por exemplo, percebe-se a perspectiva plana, conhecida como "perspectiva em voo do pássaro". Nela, o espectador é aquele a que se refere Da Vinci, em seu Tratado da Pintura, no qual o olho colocado no alto da pirâmide e abrange toda a cena. Para a formação dos jardins, existe também a perspectiva elevada, na qual o olhar depende de dupla síntese entre aquilo que é possível ser lido sobre o plano e aquilo que é verdadeiramente a experiência ativa do transeunte no espaço real do jardim. O ponto de vista duplo sobre o plano do jardim, em Inhotim, por exemplo, é colocado como uma tela; remete-se à ambivalência do estatuto do transeunte no jardim. Nesse âmbito, é preciso que o transeunte esteja dentro da paisagem (coisa dentro da coisa), elemento em movimento num mundo de movimentos. Observador é alguém que olha uma tela ou, ainda, que está de frente a um espetáculo; um espectador diante do teatro da natureza, no qual estão o vegetal, o mineral, as luzes, os reflexos dos espelhos naturais e os perfumes de capim limão ${ }^{7}$. Nesse instante, tudo ali se deve à arte e ao respeito à natureza. Inhotim apresenta uma fusão do paisagismo, da arte e das ciências (especialmente, a botânica e a óptica), onde interagem elementos latino-americanos, estadunidenses, europeus e também orientais.

\footnotetext{
${ }^{6}$ Branco de chumbo (bianco di Roma; bianco di Piombo; lead white). Essa cor tem excelente cobertura e quando usado em finas camadas é muito transparente. É considerado o branco de tonalidade mais "quente". Disponível em: < http://www.cozinhadapintura.com/2011/01/pigmentos-parte-iantiguidade.html > Acesso em: 12 ago. 2019.

${ }^{7}$ Nas galerias, o aroma de capim limão é liberado para completar a imersão, despertando o olfato para causar o efeito da realidade. O mesmo ocorre com as águas que são colorizadas de azul ou de verde.
} 
Em geral, as obras de Monet são realizadas em tondo ${ }^{8}$ - algo que, de imediato, induz o olhar para dentro de um universo sem ponto específico de referência num todo etéreo e ilimitado. Nos reflexos, onde flutuam as ninfeias, a bruma circula e a névoa sai da superfície da lagoa, espelhando os tons azuis, verdes, alaranjados e prata. A bruma para os orientais é uma expressão por excelência do vazio, do Tao em movimento, isto é do que é sem forma, mas tem a possibilidade de se condensar e tornar-se materialidade. Outra vez, o formato de tondo leva à metáfora da travessia de um portal ou, ainda, à moldura de um espelho. Nesse mundo em mutação, não há linha divisória entre o sonho e a realidade; entre o ser e o não ser. É a lei fundamental do taoísmo: o ponto fundamental que emana da obra é o vazio em movimento. Monet cria através de sua intuição, um universo sem antíteses e regido pela unidade primordial, pelo Tao em ação. Ele pinta as ninfeias alterando a cada vez o seu ponto de vista, renovando o motivo conforme as estações do ano. Leva em consideração a nuvem que passa e escurece o ambiente, o vento que sopra e movimenta os reflexos na água e a luminosidade que diminui e renasce proporcionando um espetáculo a cada minuto.

O lema é viver em plena natureza a fim de observar sua eterna mutação; é também captar instantes privilegiados da natureza: "partir do distinto, do tangível para atingir o vazio resplandecente" (MONET apud MACHADO, 1986, p. 73). E, por fim, conclui: “eu amaria pintar como um pássaro canta” (MONET apud MACHADO, 1986, p. 73).

O filósofo Chuang-Tsu (século III a. C.) escreve o seguinte: o vazio é grandeza. Ele é tal qual um pássaro que canta espontaneamente e se identifica com o universo. O vazio é um estado superior ao qual desejam ascender os grandes artistas, filosóficos e sábios orientais. O vazio é o Tao sob a forma de não ser, a forma primal de tudo que existe (MACHADO, 1986, p. 73).

Monet atinge a síntese, esse estado de vazio que se identifica com o universo, através das obras Ninfeias a partir de 1903. Mas, para ele, as ninfeias são coadjuvantes. O verdadeiro espetáculo luminoso acontece graças aos pedaços do céu que se refletem no espelho d'água, difundido a vida e o movimento a cada instante. As Ninfeias são símbolos de mutação; elas são o ponto de partida para o mundo onde reina o princípio primordial. Monet emprega sistematicamente a perspectiva como convite ao público. Ele quer que observador penetre no cosmos, no vazio.

\footnotetext{
${ }^{8}$ Tondo (no plural, tondi) é pintura ou escultura realizada sobre um suporte de formato redondo e não em retângulo como é corrente. O termo provém da língua italiana, sendo uma aférese da palavra rotondo (redondo). Disponível em: In: ENCICLOPÉDIA Itaú Cultural de Arte e Cultura Brasileiras. São Paulo: Itaú Cultural, 2020. Disponível em: 〈http://enciclopedia.itaucultural.org.br/termo119/tondo〉. Acesso em: 12 ago. 2019.
} 
O espaço, tempo e hora são substituídos por espaço, tempo e ilimitado. Graças à água e seus reflexos, ele se torna o pintor daquilo que não se vê. E é através daquilo que não se vê, através desse reflexo do absoluto pleno de paz e de luz é que a obra desafia a passagem do tempo, assim como em Inhotim. Essa instantaneidade se apresenta nos jardins Giverny (Figura 9) e em Inhotim (Figura 08). O cuidado em observar a incompletude está no fato de não reconhecer uma coisa acabada. Monet vê o minuciosamente acabado como a negação da realização em profundidade, esse deve ser o objetivo primordial na arte. Ao defender a ideia do inacabado, ele coloca de forma implícita a participação do observador como um dado fundamental. Esse observador completa a obra, permitindo dessa maneira sua plena realização.

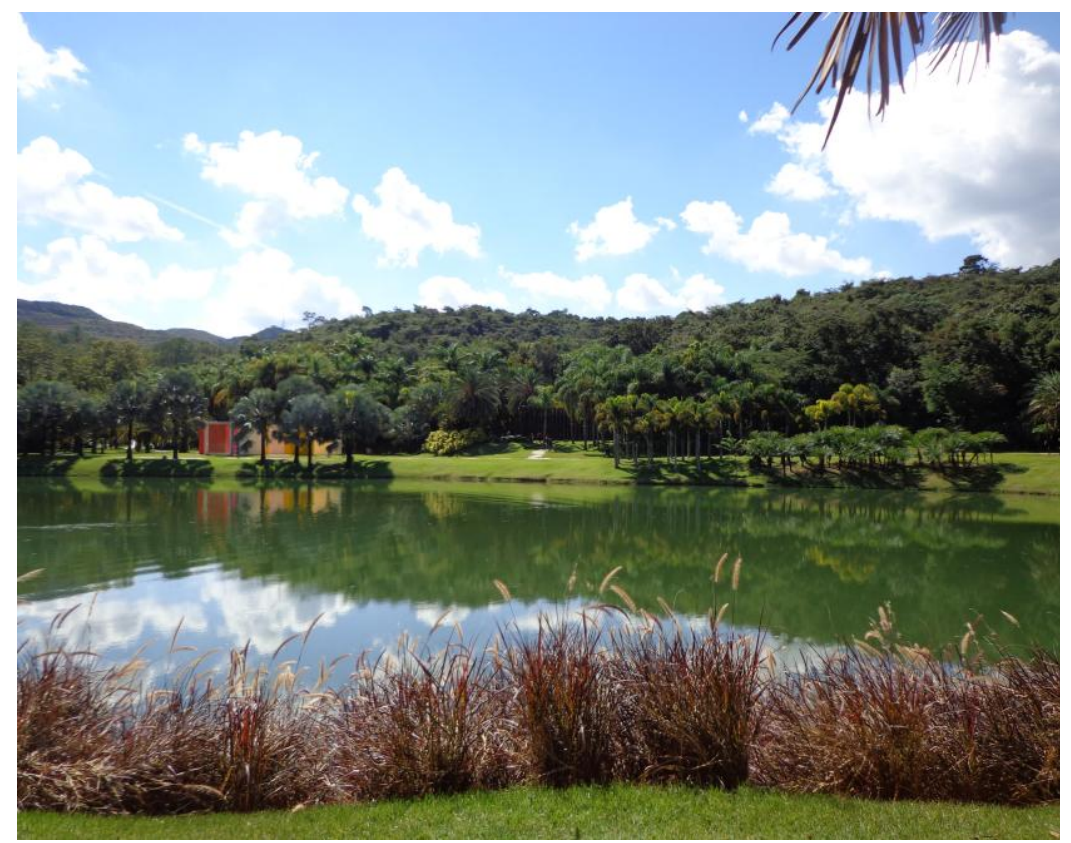

Figura 8. Espelhos d'água em Inhotim, Brumadinho/MG. Fonte: acervo da autora.

Desse modo, se estabelece o espaço do espectador, assim como a relação com o espelho e seus reflexos. Essas duas interações constituem-se a relação entre objeto, o criador e seu apreciador. Nesse sentido, as obras citadas neste capítulo auxiliam na aproximação e na compreensão do jogo de espelhos e olhares que serão discutidos nos próximos dois capítulos e, que tratam especialmente da obra Folly, de Valeska Soares, em Inhotim. O espelho é símbolo para a construção da obra, bem como na construção da memória do prazer, da dor, da legitimação, da identidade, do autorretrato, do lúdico, do imaginário, do amor e da sedução. 


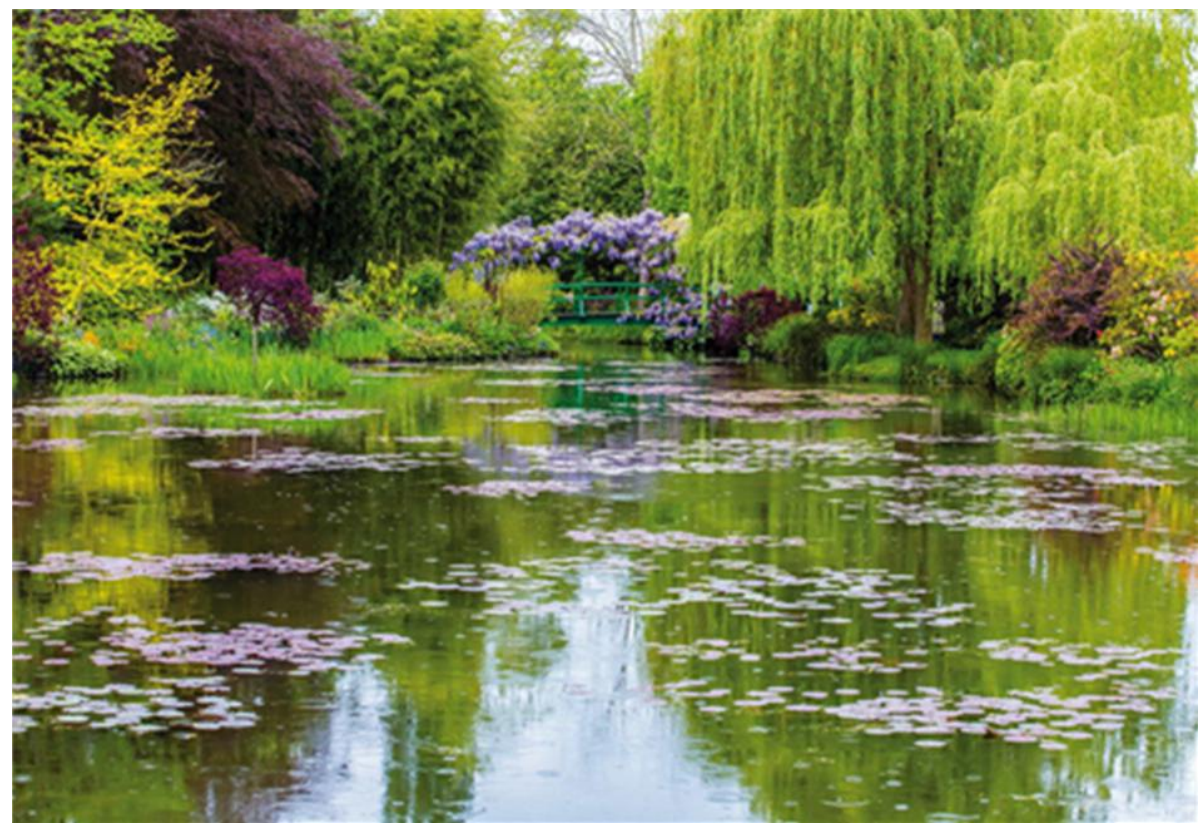

Figura 9. O lago de ninfeias com a ponte japonesa coberta por glicínias, Jardins de Monet. Fonte: Fotos Valerio Romahn. Disponível em:

https://revistanatureza.com.br/os-jardins-de-claude-monet/. Acesso em: 12 ago.2019.

$\mathrm{Na}$ junção entre pintura e paisagismo, os projetos de Burle Marx, a partir de vista panorâmica, se aproximam de pinturas, estamparias e até mesmo tapeçarias definições semelhantes à obra de Monet. Dessa maneira, as paisagens de Inhotim e as pinturas de Monet, mesmo respeitando as regras tradicionais da composição, nos distintos espaços da teoria e da prática tornam-se vivência que coloca o homem no centro das coisas e do mundo, concebendo a experiência imediata do sensível. Dentro desta esfera de paisagismos, Burle Marx, retoma algumas considerações de que o jardim é uma natureza organizada pelo homem e para o homem:

(...) Disciplina muitas vezes ajuda a chegar a um resultado. $\mathrm{Na}$ realidade, artista é aquele que consegue expressar-se com inteligência. Por outro lado, para mim a arte é uma necessidade de encontrar um autoequilíbrio. Existe, no entanto, um lado da arte que é tão imponderável quanto a vida. Se pudéssemos explicar a razão de porque temos necessidade de perpetuarmonos, de porque vivemos... (MARX apud OLIVEIRA, 2001).

\subsection{Selfies e autorretratos}

O mundo é hoje tecnológico e conectado. Nele, dispõe-se uma infinidade de recursos e escolhas sem precedentes - têm-se, cada vez mais, autonomia intermediada pela tecnologia. Nesse contexto, produzem-se, de modo independente e instantâneo, retratos e autorretratos. É completamente dispensável o auxílio do profissional-perito de épocas anteriores. Assim, um registro fotográfico é livremente realizado e, consequentemente, a memória se mantém e se perpetua - mesmo o fotógrafo não sendo 
totalmente alfabetizado. Prova disso? Basta atenção às crianças, os nativos digitais ${ }^{9}$ : a "geração anos 1990" domina os selfies (autorretratos feitos com smartphones ou webcams, geralmente, compartilhados na web).

Na pintura renascentista, por exemplo, o retrato é algo moroso, restrito e caro, isto porque ele é confeccionado somente a partir de encomenda feita a um pintor que dominasse as técnicas necessárias para o trabalho e, praticamente, é uma peça original (sem a possibilidade de ser divulgado amplamente como hoje acontece nas redes sociais). Nesse movimento entre retratos e autorretratos, alguns contemporâneos indicam a prática Velásquez como pioneiro do selfie:

Já que Velásquez sempre foi considerado um dos influenciadores de tendências posteriores, podemos afirmar também que foi um dos precursores do selfie, incorporando-se ao quadro em sua famosa tela Las Meninas. Mas esse tipo de assimilações, mais ou menos afortunadas, nos devia de verdadeiro interesse desses fenômenos sociais. Se algo caracteriza o selfie tanto quanto o meme é a sua imensa capacidade de difusão (...) (AGUIRRE e MUNAIN, 2014, p. 12).

Nesse ponto, deve-se assinalar que o selfie não surge a partir das mídias digitais da atualidade. Esse fenômeno viral é marcado pela a obra do holandês Maurits Cornelis Escher (1898-1972). Em 1935, ele segura em sua mão uma esfera, refletindo a si mesmo numa esfera espelhada em uma impressão de litografia. Na reflexão, a maior parte da sala ao redor de Escher pode ser vista e a mão segurando a esfera é revelada (Fig. 10). Autorretratos em superfícies esféricas e reflexivas são comuns no trabalho do artista. Essa imagem é o exemplo mais proeminente: em grande parte de seus autorretratos, Escher está no ato de desenhar a esfera, enquanto nessa obra ele está sentado e olhando para ela. Nas paredes, há várias fotos emolduradas, uma das quais parece ser um boneco. Na imagem, existem também estantes, móveis, outras fotos e muitos outros itens.

Conforme Flusser (1998), o retrato é um espelho que reflete. E se constrói a partir do verbo latino flectere, que se traduz por fletir ou curvar-se, e pelo anteposto re, que expressa algo que se faz "novamente" ou "para trás". Refletir, portanto, etimologicamente é "inclinar-se para trás". Nessa direção, o retrato reflete o presente do indivíduo que "reflete" (isto é, que pensa sobre a representação no futuro). O retrato por sua vez é um espelho que reflete o que já está morto no passado congelado.

\footnotetext{
${ }^{9}$ O termo "nativo digital" descreve o jovem que nasce na época das tecnologias digitais. A exposição a elas concede a essa geração talentos e características inéditas (PRESNKY, 2001).
} 


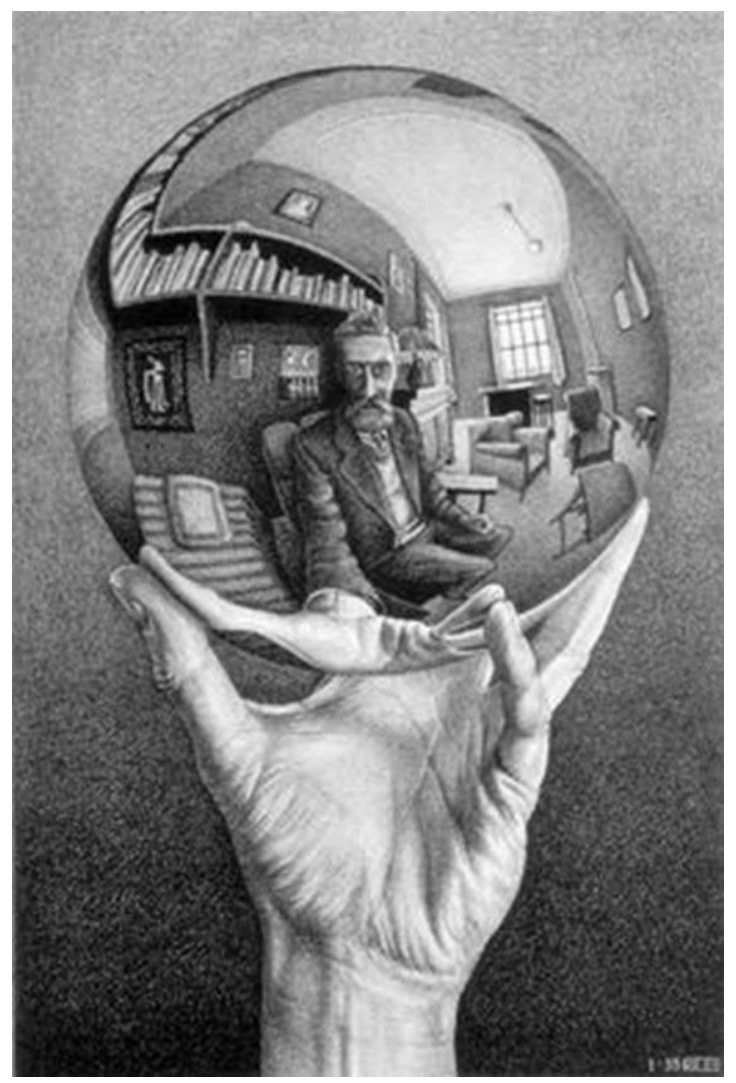

Figura 10. Escher. Mão com esfera refletora, litografia, 1935. Fonte: http://www.mcescher.com/gallery/italian-period/handwith-reflecting-sphere/. Acesso em: 04 jun. 2018.

O ato de olhar/mirar o espelho é um momento narcísico de cumplicidade, pois se ajusta ao reflexo e ao desejo. Não se trata puramente de moda, maquiagem, mudança de expressão e postura diante do aço. O maior desejo de si é a esperança de ser cobiçado ou invejado por outros. Há uma artificialidade no eu, a partir do momento que "me sinto na presença da objetiva". O olho do fotógrafo equivalente ao olho humano. Entretanto, o espelho revela, sendo possível a identificação na imagem forjada ou o repudio pela imagem. O autorretrato no espelho conduz ao próprio indivíduo ao poder de se autoconceber.

O reflexo da imagem e o observador une um ao outro, o espelho dá a impressão de totalidade do eu, na fotografia, assim como no espelho enquanto realidade virtual, o real se torna virtual, tornando-se "hiper-real" (BAUDRILLARD, 1991). Os sistemas culturais têm se multiplicado e, assim, o indivíduo contemporâneo se vê desafiado a criar novas identidades, porém, temporais. O sujeito pós-moderno transita por diferentes identidades em diferentes momentos, assume o papel que deve assumir, conforme o momento e o contexto social. 
Esse homem pós-moderno faz selfie e acredita, como práxis, que está se consolidando nesse momento da história. Mas, enquanto produto/produção, esse é volátil, uma vez que o registro fotográfico desse momento logo será substituído por outro que também terá vida breve. Eles não deixam de existir, porém, ficam ultrapassados por um novo selfie. Um selfie pode espelhar um instante real de uma pessoa ou ser a personagem criada para aquele dia ou para um propósito específico, nem sempre revelará algo que está interiorizado nela.

Sendo assim, a tecnologia alcança um nível de perfeição que homogeneíza a obra de arte, criando um padrão que antes de sua criação é somente permitida ao mais habilidoso pintor ou escultor. Há uma uniformização técnica. Diferente dos retratos na Renascença que só as pessoas abastadas têm acesso, o selfie é uma prática bastante usual entre todas as classes. A self se caracteriza pela propagação e circulação da imagem de si mesmo, em situações do cotidiano. Face à velocidade que se propaga, alcança todos os contatos do seu autor de forma instantânea, basta conexão.

\footnotetext{
O selfie parece uma obsessão do homem pós-moderno, quem não posta fotos na rede pode não existir. As pessoas querem ver e, sobretudo, serem vistas. Através do selfie a pessoa pode construir sua imagem, criar um personagem, uma nova identidade, mesmo que virtual, faz recortes de fatos e situações, e dispara aquilo que deseja expor sobre si e seu cotidiano. Através da prática do selfie, as interações pessoais foram alteradas. Não há possibilidade de refletir sobre o selfie sem passar pela fotografia e a necessidade do homem de deixar marcas de seu cotidiano em diferentes aspectos, mas sempre sob o recorte de seu olhar para a realidade (COHN, 2015, p.6).
}

Nessa perspectiva e reflexão sobre os autorretratos e selfies, sabe-se que espelhos e reflexos são muitos. Há, entre eles, os que existem fisicamente no mundo dos objetos cotidianos. Esses operam reflexões, inflexões, desvios dos raios luminosos que formam a imagem em sua superfície. E possuem como princípio um artifício que enquadra as cenas e tudo mais que se coloca no seu horizonte. São espelhos constituídos, produzidos e manipulados pelo homem e, seu núcleo essencial se configura como simuladores potentes chamados de real.

Então, recomenda-se o exemplo de Alice. Ela, à beira de um sonho quase pesadelo, descobre uma inédita função para o espelho da sala. Ela encontra uma fantástica passagem para uma nova dimensão povoada por seres muito estranhos. Um mundo onde impera o absurdo, certo desconforto e temor em se observar no espelho e ser observado por ele. Ao se entreolharem, o duplo pergunta para o outro, assim como a Lagarta dirige-se à Alice na história: 
- Quem é você? Ela responde meio encabulada: - Eu... eu mal sei, Sir, neste exato momento... pelo menos sei quem eu era quando me levantei esta manhã, mas acho que já passei por várias mudanças desde então. Pois eu mesma não consigo entender, para começar; e ser de tantos tamanhos diferentes num dia é perturbador. E novamente, a Lagarta pergunta: quem é você? Pergunta de espelho, pergunta que sempre volta para sua origem sem resposta (CARROLL, 2010, p.56-57).

O espelho é o ponto de partida para o conhecimento da pessoa que a imagem representa. O homem contemporâneo busca a si na imagem "selficada". É uma espécie de autorretrato produzido a partir dele, ou seja, da imagem captada. Com isso, na teoria platônica, o reflexo do espelho se torna especificamente análogo ao sélfico, a (re) produção de uma nova imagem do homem, com base nos seus "autorretratos", ora como exibição de si, ora como autoafirmação de uma autoimagem. No autorretrato ou selfie, o indivíduo busca controlar o modo como ele é visto; simulado.

Em relação ao narcisismo e hedonismo, muitos artistas desenvolvem esse tema, constituindo produções de múltiplas identidades do sujeito. Artistas se utilizam de diferentes modos de produção de subjetividades, buscando as possibilidades de o sujeito problematizar a si, enquanto constituição fragmentária de produções desejosas de seus eus.

Na questão da imagem de si a artista brasileira, Helga Stein (1975) propõe a discussão da identidade e do narcisismo mediada por novas tecnologias digitais. Ela mesma "se fotografa", desdobrando sua imagem em outras estranhas e diferentes, manipulando pixel por pixel, em sua matriz original, dando asas à imaginação. A artista manipula seu autorretrato, transformando-se em mil novos autorretratos e novas faces: ela transforma a cor de pele, a estrutura óssea. É uma verdadeira metamorfose, a ponto de perder de vista, a sua origem, sua verdadeira autoimagem e sua matriz original. A verdadeira identidade é consumida no meio de tantas caricaturas de si, retoma-se a ideia dos conceitos Platônicos, tratados no capítulo 1.

O projeto, iniciado pela artista em 2004, chama-se Andros Hertz (Fig. 11). São ensaios variados que formam uma galeria de "personagens" compostos e manipulados a partir de autorretratos alterados digitalmente. Todos publicados no site Flickr. Por meio cibernético, ela manipula a sua imagem questionando o valor da autenticidade de sua própria identidade, forjando encenar e simular sua imagem. Sua obra serve para questionar a crença na realidade. $\mathrm{O}$ indivíduo construído e manipulado por editores, no qual o virtual se sobrepõe ao real, tornando-se secundário. Helga e suas personas, de existência restrita à imagem, pulsam intensamente no mundo da expressão. Imagens 
manipuladas perdem sua origem, a localização no tempo e no espaço. Assim, a artista constrói sua própria autoimagem e propõe questões sobre o fenômeno na contemporaneidade: a "neurose das selfies", uma vez que neurose está relacionada com a questão da compulsão e repetição, bem como a obsessão pelo eu que deve ser admirado, elogiado e narcísico. Segundo a artista, a captura da identidade tem o enfoque central na promoção do desejo de compartilhar, sair do anonimato para evidenciar, abertamente, seus interesses, opiniões, gostos, estados emocionais de seus eus-possíveis, por meio de signos e personagens imaginários, cuja presencialidade visa apresentar a si mesmo, uma espécie de neonarsicismo on-line e virtual.

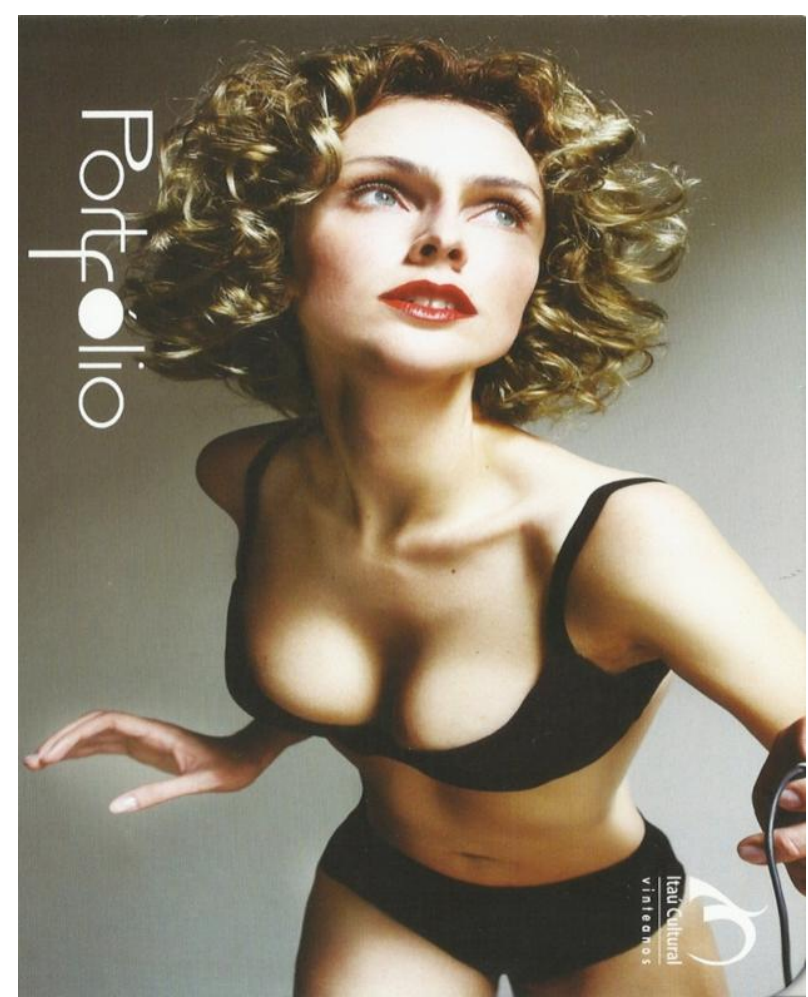

Figura 11. Helga Stein, Andros Hertz, fotografia digital, 2004. Fonte: http://ederchiodetto.com.br/portfolio-helgastein-texto-do-curador/. Acesso em 04 de jun. 2018.

Outra artista, mestre em disfarces, é a estadunidense Cindy Sherman (1954). Em seus ensaios, ela produz a desconstrução do indivíduo. Sherman captura-se numa variedade de formas e personagens que são divertidos e perturbadores. Para criar suas fotografias, ela assume várias funções, entre elas, fotógrafa, modelo, maquiadora, cabeleireira, estilista e figurinista. Para Arlindo Machado (2001), a artista propõe a pose, a encenação e a simulação como elementos da concepção da identidade em atitude teatral nas imagens. 
Para Sherman, fotografar consiste menos em apontar a câmera para alguma coisa preexistente e ficar sua imagem na película que em criar cenários e situações imaginárias para serem oferecidas por ela, tal como acontece no cinema de ficção. A fotografia é concebida com criação dramática e cenográfica ou como mise-en-scène, na qual a fotógrafa interpreta ao mesmo tempo os papéis de diretora, dramaturga, desenhista de cenários e atriz (MACHADO, 2001, p.134).
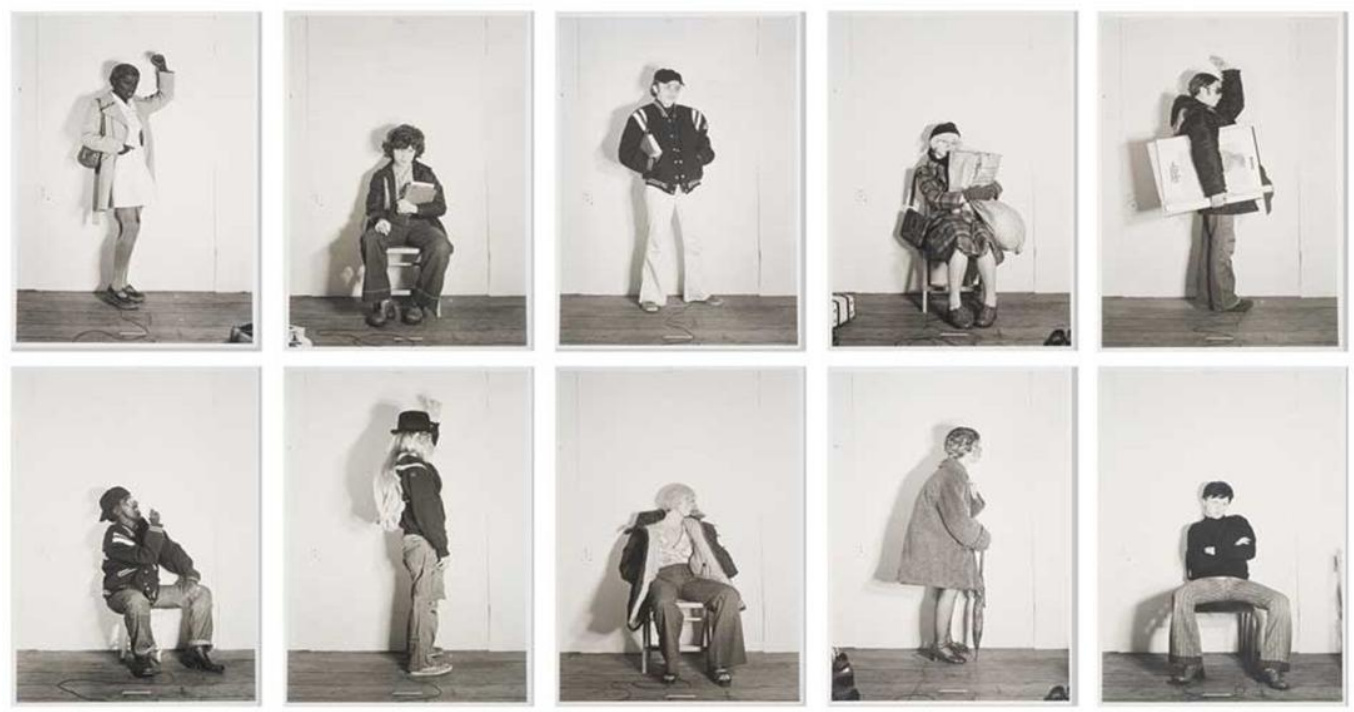

Figura 12. Cindy Sherman, Sem título. Bus Riders, 1976/2005. Fonte: http://www.ggart.com/news/photoshow/10607611.html. Acesso em: 05 jun. 2018.

Através da manipulação digital, Sherman cria mais de dez personagens diferentes (Figura 12). Ela traz em seus projetos fotográficos a representação e autorrepresentação; são híbridos entre tableau e performances. Na sua obra, o tableau remete a Narciso diante de seus reflexos disformes; reflete seus "eus" disfarçados. A artista produz autorretratos dissimulados com personagens que, na maioria, são ficcionais vindos da literatura e do cinema. Com um arsenal de perucas, figurinos, maquiagens, próteses e adereços sofisticados, Sherman habilmente altera seu físico e os arredores para compor cada "tableaux vivants" - termo usado por Dubois (1994, p. 142) para designar "tábua-água” e/ou "pintura viva”, fazendo menção ao reflexo de Narciso. Quando o ser mitológico olha para o espelho d'água se apaixona pelo próprio reflexo.

Sherman constrói personagens intrigantes, tais como, socialite, atores famosos, personagens cinematográficos, homens, mulheres, crianças, palhaços, quase uma 
pantomima. Seu corpo é o suporte table (quadro/corpo), eau (disfarces/espelhos disformes do eu). Ela descaracteriza-se de si, criando novos indivíduos, virtualizando e manipulando a própria imagem. A artista emprega a noção de espelho como um artifício, um instrumento de descobertas e construções, exercendo total domínio na produção dos seus "eus" imaginados e de múltiplas personas.

Jorge Molder (1947) é outro artista que trabalha com fotografia, usando espelhos. Sua obra pode ser entendida como um exercício continuado sobre o autorretrato. A rigor, a maioria das fotografias desse artista português, tem no seu próprio corpo a matéria de eleição. São imagens do corpo do artista com ênfase na incidência das mãos e rosto. Ressalta-se que é necessário afastar o trabalho de Molder do universo do autorretrato e aproximá-lo da prática genérica da autorrepresentação. Segundo o pensamento de Melo (1999, p. 7-14):

\footnotetext{
Molder tem o interesse pela exploração do território estético e politico da duplicidade, pela convulsiva divisão do ego, por este fenômeno de estranheza que é achar-se outro na própria imagem (...). O eu que narra estas fotografias conta histórias sobre como, sob o olhar dos outros, vai envergando as suas personae, ou máscaras, pondo e tirando suas várias naturezas. $\mathrm{O}$ eu passa a ser a forma como me veem.
}

As primeiras experiências com a imagem do seu corpo resultam na criação de uma série intitulada Autorretratos (1979/1987). Em algumas dessas imagens é notório o recurso a expedientes técnicos e formais. Molder não se autorretrata, subtrai-se, criando o espaço indispensável para a coexistência de outro no seu corpo, ou seja, um duplo. $\mathrm{O}$ autorretrato constitui-se como a grande obsessão de Jorge Molder. O artista surge no mundo sendo, simultaneamente, protagonista e modelo. Na sua produção, evidencia-se a dicotomia fotógrafo versus modelo, arte versus imagem, obra real versus alma. Autorretratos tem como limite ontológico do ser humano, a morte. Oscila entre os limites da racionalidade e a perda de razão. Apesar de o artista ser o próprio modelo, para o fotógrafo não se trata de autorretratos, já que não existe uma preocupação introspectiva, uma problematização de si no sentido pessoal e autobiográfico que caracteriza geralmente o autorretrato. As suas imagens são, portanto, imagens corporalizadas (MARCHAND, 2002, p.14).

$\mathrm{Na}$ (Figura 13), o artista atua como protagonista e modelo, da mesma maneira que Sherman trata a própria anatomia como suporte da própria arte, construindo e desconstruindo novos "eus". 


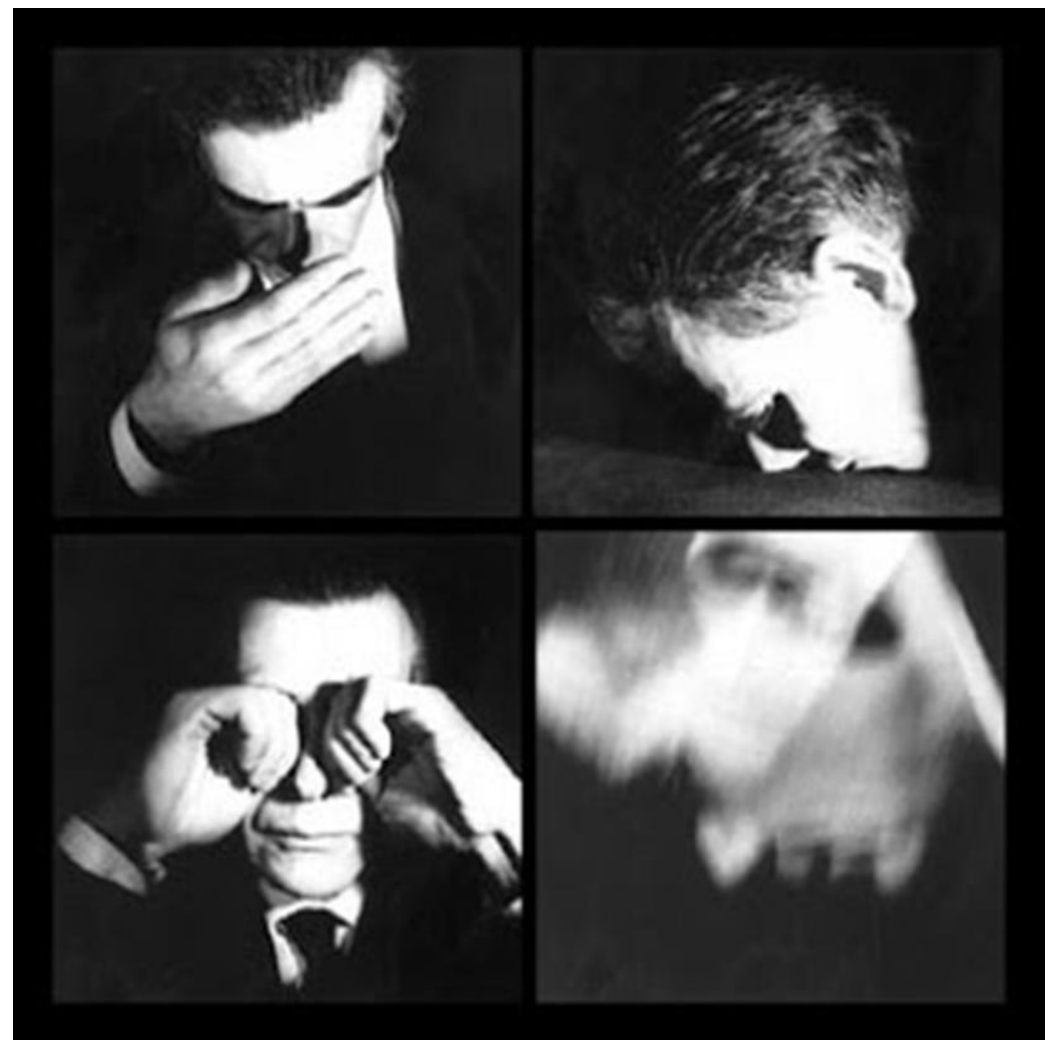

Figura 13. Jorge Molder, Autorretratos, (1979-1987). Fonte: https://fasciniodafotografia.wordpress.com/2016/09/19/jorge-molderanatomia-e-boxe-1997/. Acesso em 05 jun. 2018.

A fotógrafa Vivian Maier (1926-2009), com mais de 150.000 imagens de Nova York e Chicago, entre os anos de 1950 e 1970, revela a vida nas ruas da modernidade norte-americana. Esse imenso acervo legado por uma mulher que vive e morre na obscuridade, permite levar a cabo uma reflexão de Baudelaire sobre um tempo em que o homem, esse solitário dotado de uma imaginação ativa, viaja através do grande deserto de homens, como um flâneur (BAUDELAIRE, 2004, p.25). Assim é o olhar de Maier, cercado por uma atmosfera de solidão e de reclusão em meio ao vidro, vitrines, reflexos e espelhos (Figura 14). O vidro é seu universo (BRONDO, 2013, p.71-84). O que interessa à pesquisa são seus autorretratos e a sua imagem projetada em superfícies refletoras, seja na água, sua própria sombra projetada no chão, na vitrine, seus espectros sendo projetados em meio aos grandes centros urbanos. 


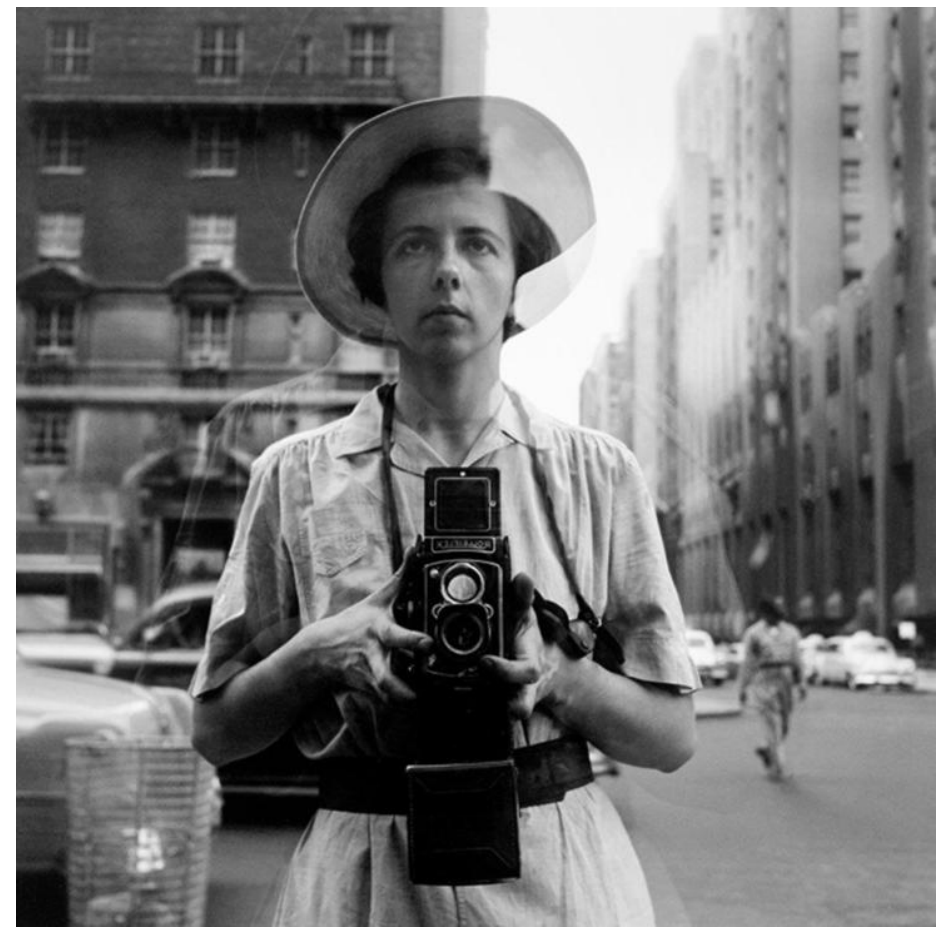

Figura 14. Vivian Maier. Autorretrato, s.d. Fonte: http://www.vivianmaier.com/gallery/self-ortraits/\#slide-16. Acesso em 05 jun. 2018.

Em Inhotim, os reflexos da instalação de Valeska Soares se projetam na paisagem do entorno, no octógono espelhado, como as fotografias de Maier que refletem a cidade através dos reflexos urbanos nas vitrines retratadas. Os reflexos, sobretudo, não são autorretratos, como em Maier, mas sim selfies do público que ressignificam os sentidos da obra à medida que se aproximam dela e a exploram. Observa-se que na obra de Valeska Soares a autoria da obra se transforma, conforme a interação do público que faz selfies em frente ao octógono. Nela, o narcisismo é ativado pelo espectador e não pelo artista, como se observa em Maier, Sherman, Molder e Stein que aparecem na obra como sujeitos representados ${ }^{10}$.

Solitária, Maier observa tudo e, simultaneamente, cativa seu espectador, criando um espaço de sedução. A artista lida com a distância entre o real e seu duplo. A

\footnotetext{
${ }^{10}$ No capítulo 3, essa questão será abordada com maior profundidade.
} 
distorção entre o eu e o outro é abolida. Inclinado sobre sua fonte, Narciso sacia sua sede. Sua imagem já não é outra, mas a própria superfície que a absorve e seduz. De modo que a artista só aproxima-se sem nunca ir mais longe porque não é mais lá, como não é nenhuma distância reflexiva entre Narciso e sua imagem. O espelho de água não é uma superfície de reflexão, mas uma superfície de absorção (BAUDRILLARD, 1981, p. 64-65).

Nesse refletir, Maier proporciona esse efeito de maneira narcísica, a imagem refletida na superfície se mistura, transportando o espectador para outro universo. No $O$ Autorretrato, s.d, (Figura 14), ela está na rua se fotografando numa vitrine. Maier explora o mundo todos os dias. Nele, encontra personagens tais como no espelho de um estranho. A maioria de suas imagens corresponde aos instantâneos de rua e retratos, mas seus numerosos autorretratos são uma espécie de correlativa que não parecem pertencer a esse mundo: reflexões em espelhos e armários, reproduzindo um rosto neutro, cujos olhos miram atentamente, ausente de senso de identidade e de pertencimento.

Em outros autorretratos, a ênfase recai sobre sua sombra, que substitui seu rosto. Nesses, a artista é jogada em diferentes superfícies. Ver o mundo e ver-se faz com que o espectador sinta estranheza e distanciamento. Esse legado tem uma dupla leitura: ser a memória dos personagens e de cenários que estão destinados a desaparecer, mas também ser o diagnóstico de vertigem de mercadorias em vitrines. Ela não faz nada, mas enfatiza através de seu reflexo num vidro transparente a condição de isolamento de si e das multidões no cenário das grandes cidades.

Já Francesca Woodman (1958-1981), outra artista estadunidense, apresenta em suas fotografias "a problemática do sujeito-objeto como desaparição" (BARBON, 2010). Sua ausência física se dá por imagens que se desvanecem, se camuflam e se fragmentam, "numa desconstrução do ato fotográfico" (BARBON, 2010). É possível dizer que "a artista criou um mundo de exploração e delírio corporal, autorrepresentativo e inquiridor do fotográfico, deixando como herança uma obra que é presença sutil de reminiscência e libertação" (MENDES, 2011). Para Barbon (2010), “[...] a dissolução do eu enquanto potência expressiva não representa nem um corpoespetáculo, nem um corpo-objeto, pois perde sua materialidade, sua identidade perdendo seu ato de significar". O desaparecimento do sujeito-objeto forma sua poética, explorando sua relação identitária, sua ausência num espaço escolhido. Geralmente, os cenários são edifícios abandonados, destruídos, numa espécie de extensão do eu fragmentado com o espaço e o cenário ao redor de si (Figura 15). 
A ideia de Woodman dialoga com o pensamento do filósofo francês Maurice Merleau-Ponty (1999, p. 57):

Visível e movendo meu corpo é como pertencente entre as coisas, é uma delas, ele é levado para o tecido do mundo e sua coesão é a de uma coisa. Mas desde que ele vê e se move, mantém as coisas em um círculo em torno dele, as coisas é um seu apêndice ou a sua extensão, está incrustada na carne, eles são parte de sua definição plena, e o mundo é feito do mesmo tecido do corpo.

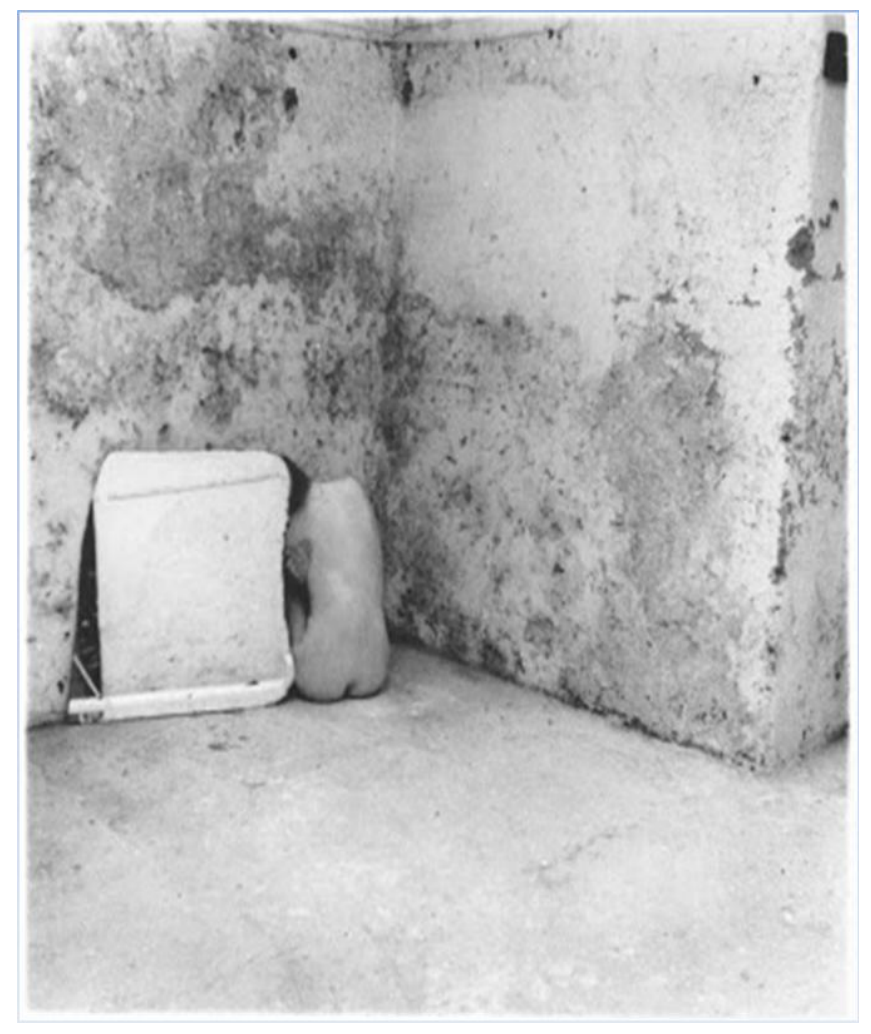

Figura 15. Francesca Woodman, Self- deceit, fotografia, 1975. Fonte: https://art.nationalgalleries.org/art-andartists/85849. Acesso em 04 jun. 2018. 


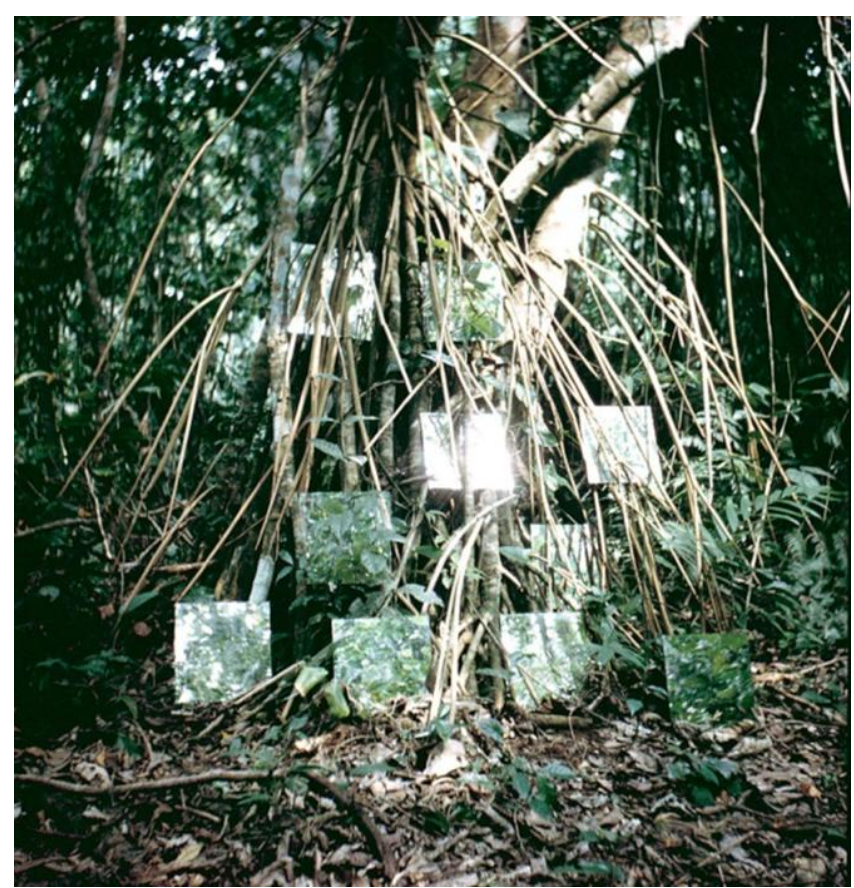

Figura 16. Robert Smithson, Yucatan Mirror

Displacements, 1969. Fonte:

http://www.guggenheim.org/newyork/collections/collectio nonline/artwork/5322, acesso em: 04 jun. 2018.

Outro artista contemporâneo, Robert Smithson (1938-1973) procura uma forma estética limítrofe com o mundo em geral (Figura 16). Seus fragmentos retirados de uma paisagem emoldurada dentro de uma galeria quebra a polaridade entre o dentro e o fora, deixando aberta a possibilidade de um terceiro termo que conteria ambos.

Tempo e o fenômeno da entropia eram centrais para seu projeto e a fotografia foi $\mathrm{o}$ meio perfeito para capturar o processo $\mathrm{e}$ os efeitos de duração/continuidade. $\mathrm{O}$ ato de fotografar - como as atividades de mapeamento, medição, escavação, vazamento, espelhamento e escrita - era um componente essencial da prática de Smithson (SPECTOR, 2016, tradução autor).

Quando está no México, em 1969, Smithson cria a obra Yucatan Mirror Displacements, com a instalação de espelhos dispersos na paisagem (Figura 16):

Os espelhos refletem e refratam os arredores deslocando a solidez da paisagem e quebrando as suas formas. Parte terraplenagem e parte imagem, os deslocamentos contemplam temporalidade; enquanto o espelho registra a passagem do tempo, a sua fotografia suspende o tempo (SPECTOR, 2016, tradução autor).

$\mathrm{O}$ ato de refletir a paisagem traz o efeito de refletir o que está à frente do espelho, o mesmo acontece com o tempo, com a paisagem e as com as pessoas, sempre transformando os sentidos da obra, como acontece na obra Folly de Valeska Soares. 
Ainda no âmbito das esculturas, Anish Kapoor (1954) mobiliza o público (Figura 17). Tudo é feito em grande escala. Esculturas feitas de vidro, luz, metal, cera e fumaça. São portas para outros mundos; passagens para um universo desconhecido e imaginado por ele. Kapoor diz não gostar do rótulo "arte pública". Ele explica, não deve fazer o seu trabalho para o público: "[o público] precisa explorar seu próprio território." O mistério não está no trabalho em si, mas no que pode vir depois dele, através dele. Ele surpreende a todos quando afirma que são destituídas de mensagens e que não devem ser classificadas como arte pública ou consideradas espiritualistas nem autobiográficas. Kappor comenta que a limitação do olhar, a impotência do olhar de quem está diante da obra, não consegue dar conta do que ela representa, provocando esse desejo do contato direto e tátil (NEPOMUCEMO, 2016). A impotência do olhar faz o observador se acostumar com o que está vendo para enxergar realmente o objeto na sua totalidade. Kappor traz em suas obras grandes dimensões que chamam para a participação e nesse aspecto da participação, considera-se, então, o especular. Seu trabalho se estabelece na forma, mas a forma virada pelo avesso. O efeito especular transmite a sensação de entrar em outro universo, trazendo novas ressignificações, pois quem a contempla, também se contempla, mesmo que em escalas desproporcionais.

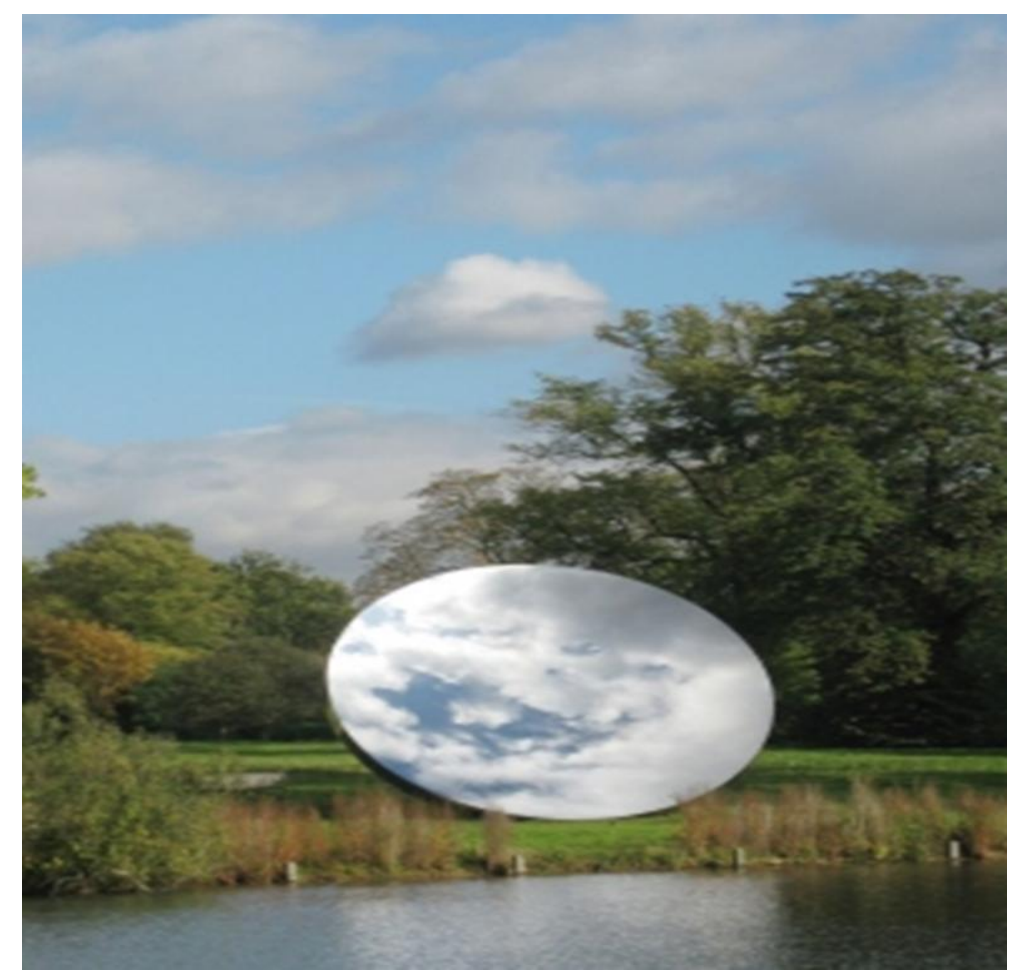

Figura 17. Anish Kapoor, Sky Mirror, 2006. Fonte: http://cartamaior.com.br/?/Editoria/Mi diaA-arte-magica-do-indianoAnish-Kapoor-em-Sao-Paulo/12/12683. Acesso em 04 jun. 2018. 
Regressando à linguagem fotográfica, o português Rui Calçada Bastos (1971) cria visões surrealistas, viajando com uma mala feita de espelho (Figura 18). Esse misterioso objeto projeta um tipo de fotografia dentro de uma fotografia. O universo é revelado para parecer ilusório, justaposto fortemente com a realidade concreta de viajar ou de sair de casa para outro lugar. Essa mala mágica, ao contrário de outras de sua espécie, não contém bens terrenos, mas momentos transitórios, em duas cenas bidimensionais visíveis apenas por um momento. A mala está cheia de miragens efêmeras que se transforma no tempo e no espaço. Ele orbita em torno de si e de seus arredores, como se tudo pudesse desaparecer a qualquer momento, como se o reflexo da mala pudesse transformar em miragem o que está refletindo. Todo o filme se passa pela mala refletora que o protagonista carrega com ele. Do próprio homem raramente se vê mais do que a mão carregando a mala. É quase como se o homem sem nome fosse apenas um veículo, como se ele não estivesse realmente presente, em nenhum lugar, em qualquer lugar. E o olhar do espectador também está condenado a permanecer para sempre vagando, sem saber para onde chegar, de quem é aquela mão que segura. Observe-se que tudo o que a mala projeta é uma miragem, uma lembrança de algum lugar que nunca se chega; lugar de negação e de refração.

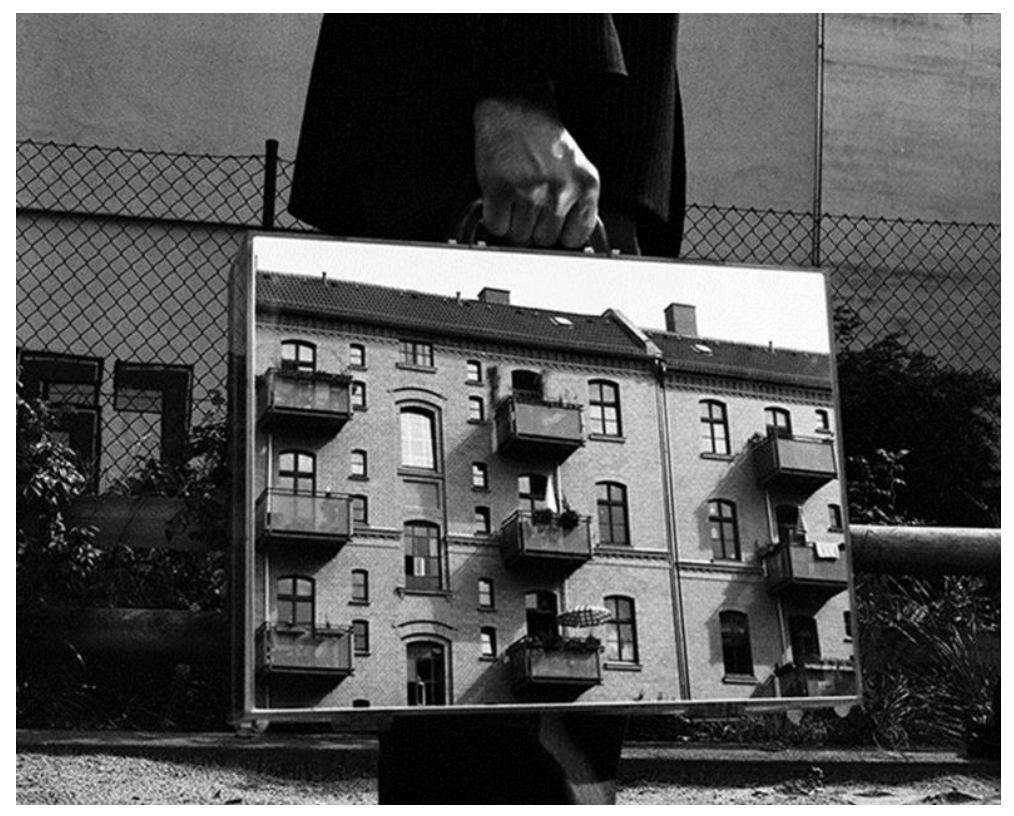

Figura 18. Calçada Bastos, In the mirror suitcase man, video art. The Mirror Suitcase Man, 2004. Fonte: http://www.ruicalcadabastos.com/index.php/photographs/the-mirror-suitcaseman-2004/. Acesso em 04 de jun. 2018. 
Assim sendo, os artistas enfrentam uma equação instigante na criação dos autorretratos: como fazer com que sua visão alcance sua própria face e assim superar o dilema posto pelos olhos que veem e que não se deixam ver? Os artistas, pintores com maior frequência, recorrem à mediação de dispositivos diversos, tais como, água parada, vidros, superfícies reflexivas etc., acabando por eleger o espelho "como um instrumento inestimável para a arte do autorretrato". O uso do espelho na arte do retrato projeta a imagem do artista sobre si e para si, uma imagem que a ele se oferece nas práticas labirínticas do autorretrato. A feitura de um retrato ou autorretrato demanda uma ação dedicada e delicada de um longo tempo na observação. Realidade nua, o espelho obriga a encarar as verdades em tempos diversos, confronto com o que se é e como o que gostaria de ser.

Nessa relação artista-sujeito-objeto, Deleuze (2005, p. 63-65) discorre sobre a obra do pintor irlandês Francis Bacon (1909-1992), quando afirma que: "a tarefa da pintura se define como a intenção de fazer visíveis forças que não o são". Indo para o campo da litogravura (Figura 19), Bacon cria imagens refletidas em espelhos que mostram a alteridade. Esses trabalhos não são um simples reflexo, eles são como uma entidade autônoma e perturbadora que aparece com um ar ameaçador e sombrio que intriga e inquieta. $\mathrm{O}$ original e a cópia estão virados; evitando-se e não reconhecendo a existência do outro, alienação de si mesmos.
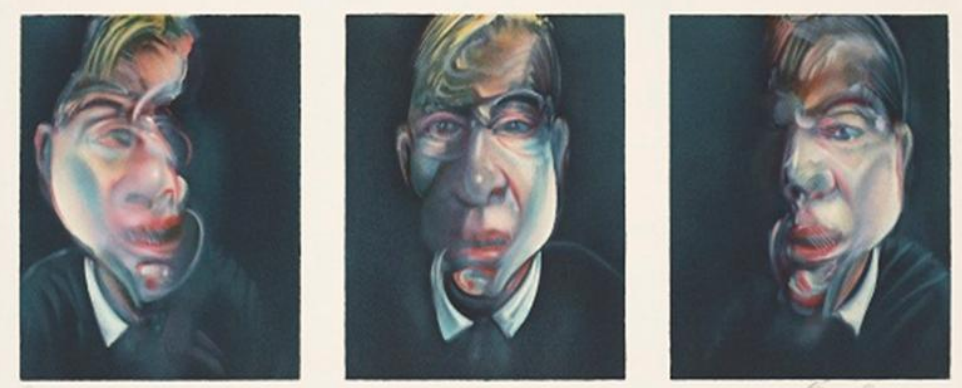

Figura 19. Francis Bacon, Três estudos para um autorretrato, três litografias em cores impressas em uma folha, 1981. Fonte: https://www.christies.com/sales/francis-bacon-the-complete-printsoctober-2013/self-portrait.aspx. Acesso em: 17 jun. de 2019.

Nas pinturas de Francis Bacon, os corpos liquefazem em relatórios massas de carne, é a aniquilação indolor, fascinados pela estranheza da realidade, torcendo corpos, jogando para desvincular as harmonias e procurando por dobras que investigam possibilidades estéticas da desigualdade. O reflexo é o outro, da desigualdade. A reflexão é o outro, é ser e é carne, não é o ator principal apenas por causa de sua localização, mas pode nos interessar mais 
do que o indivíduo que ocupa o centro da imagem. Francis Bacon pega figuras distorcidas que se mutilam ao executar metáforas psicológicas da fuga do eu, do desdobramento e mesmo o encontro convulsivo (...) que parece engolir ou ser fagocitado (LAENAERS, 2013, p. 149, tradução autora).

Ocasionalmente, Bacon volta o olhar para si. Ele não gosta da vista. "Eu abomino meu próprio rosto", ele disse uma vez, acrescentando: "eu fiz muitos autorretratos, na verdade, porque as pessoas estão morrendo ao meu redor como moscas e eu não tenho mais ninguém para pintar além de mim mesmo". No entanto, encontra-se a mesma sensibilidade em suas autointerpretações, como em seus retratos de queridos amigos. Como a especialista em estampas de Christie, Lucia Tro Santafé, observa aqui em sua desconstrução de Três estudos para um autorretrato (1979-80), a ausência é a brutalidade distorcida; em seu lugar, vê-se um silêncio, mais suave - assombrando, talvez, mas simpatizante. "Eu só quero ter a essência de uma pessoa e a emanação", Bacon afirma em certo momento. Seu objetivo na criação de retratos é encontrar uma técnica que pudesse transmitir o que uma pessoa está sentindo - o fato de a pessoa não ser um objeto, mas carne e sangue. Suas pinturas, frequentemente, fazem forte referência à carne e ao sangue, ou seja, à realidade.

Ele quase sempre usa o tríptico em seus retratos. Produz três versões de um rosto porque há três partes no rosto humano - a vista frontal, onde você vê totalmente os dois olhos e, depois os lados esquerdo e direito. $\mathrm{E}$ as pessoas parecem diferentes desses três ângulos. Ele gosta de dizer que: "é por isso que, quando você é preso, tira fotos de seus três lados". Há sempre esse sentimento de movimento entre as três imagens de seus trípticos. A prática também relembra na história da arte a tradição da Idade Média de representar cenas religiosas em três partes - de acordo com a iconografia tripartida da crucificação e da Santíssima Trindade.

$\mathrm{Na}$ Figura19, há contraste do chiaroscuro com a bochecha branca e o fundo escuro é muito barroco. A pintura parece transmitir essa ideia de tentar encontrar a luz dentro da escuridão. E talvez seja por isso que ele retrata todos esses rostos atormentados sempre. Ele gosta de ver o bem e o mal nas pessoas. Ele quer representar a natureza animal existente nos seres humanos. Mas, nesse caso, seu autorretrato é mais calmo - não agitado quanto os retratos de outras pessoas. 


\section{Capítulo 2 Inhotim}

\subsection{Site specific e jardim botânico}

O Instituto de Arte Contemporânea Inhotim é um site specific ${ }^{11}$ estruturado como um complexo arquitetônico, constituído por uma sequência linear de galerias e obras de arte, em meio a um parque ambiental, caracterizando-se como local com iniciativas multidisciplinares, abrangendo áreas de pesquisa, educação, meio ambiente e arte. Sob essa característica, torna-se relevante a definição do Instituto Brasileiro de Museus (IBRAM, 2008) sobre a definição de museu:

O museu é um lugar em que sensações, ideias e imagens de pronto irradiadas por objetivos e referências ali reunidas iluminam valores essenciais para o ser humano. Espaço fascinante onde se descobre e se aprende, nele se amplia o conhecimento e se aprofunda a consciência da identidade, da solidariedade e da partilha. Por meio dos museus, a vida social recupera a dimensão humana que se esvai na pressa da hora. As cidades encontram o espelho que lhes revele a face apagada no turbilhão do cotidiano. E cada pessoa acolhida por um museu acaba por saber mais de si mesma.

Nesse sentido, Inhotim proporciona uma experiência dialógica e interativa que permite, através da arte e do meio ambiente, o conhecimento interdisciplinar. Assim sendo, Inhotim é classificado como um ecomuseu ${ }^{12}$ ou "museu ecológico", ou seja, um museu ligado ao meio ambiente isto porque a natureza sustentável está em sua origem. Conforme o seu fundador Bernardo Paz (apud MELENDI, 2017, p. 337) relata: "sempre pensei nisto como em algo público, o único objetivo rentável para que perdure para sempre”. Desse modo, como ecomuseu, Inhotim realiza ações e pesquisas botânicas, com ênfase na educação, diante de um atual estágio de degradação do meio ambiente no planeta. Visitas mediadas e agendadas acontecem com a finalidade estimular o desenvolvimento de atividades e conscientização ambiental junto ao público em geral.

11 O "sítio específico" refere-se às obras criadas de acordo com o ambiente e com um espaço determinado. A noção de site specific liga-se à ideia de arte ambiente, que sinaliza uma tendência da produção contemporânea de se voltar ao espaço, incorporando-o à obra e/ou transformando-o, seja ele o espaço da galeria, o ambiente natural ou áreas urbanas. Disponível em: < Site Specific. In: ENCICLOPÉDIA Itaú Cultural de Arte e Cultura Brasileiras. São Paulo: Itaú Cultural, 2019. Disponível em: <http://enciclopedia.itaucultural.org.br/termo5419/site-specific〉. Acesso em: 29 nov. 2019.

${ }^{12}$ Termo cunhado no Comitê Internacional dos Museus da UNESCO em 1971. O conceito "ecomuseu" é gestado por Hugues de Varine, porém, seu esboço já existe nos pensamentos de Georges Henri Rivière. Varine define "museu ecológico" como o museu do homem e da natureza. Disponível em: <https://pt.wikipedia.org/wiki/Ecomuseu>. Acesso em: 25 de jun. 2018. 


\section{(4) OBJETIV SU S SUSTENTAVEL}
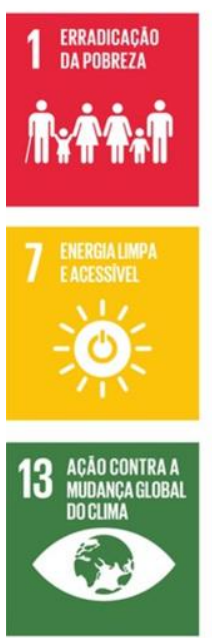
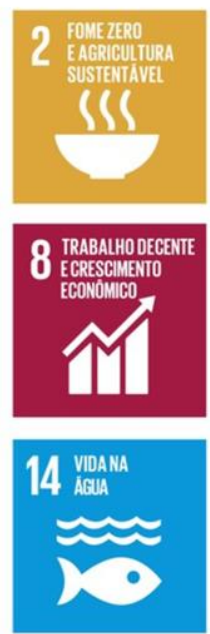
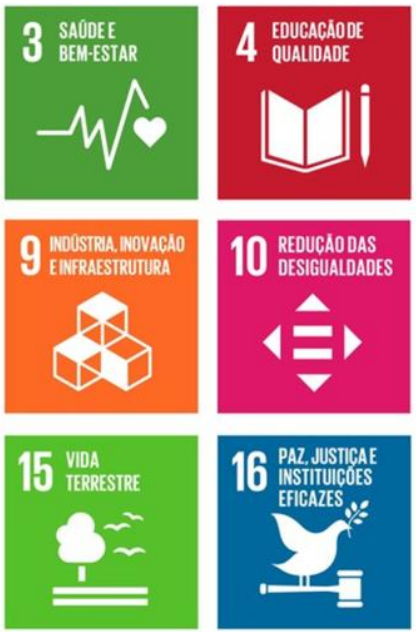
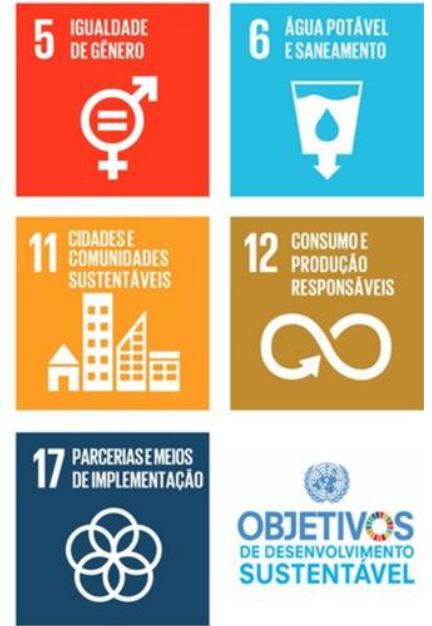

(9)

OBJETIVOS

DEEESENVOVVMENTO

Figura 20. Transformando nosso mundo: a agenda 2030 para o desenvolvimento sustentável. Fonte: 〈https://nacoesunidas.org/pos2015/agenda2030/>. Acesso em 23 out. 2019.

De acordo com informações coletadas no site oficial, um importante passo para o processo de internacionalização de Inhotim é dado: o Instituto, em 2015, assina o Memorando de Entendimento em parceria com o Programa das Nações Unidas para o desenvolvimento (PNUD). O documento trata sobre a formulação de estratégias de sustentabilidade, em alinhamento com a Agenda 2030 para o desenvolvimento sustentável e os objetivos globais (Figura 20). O documento lista 17 objetivos a serem alcançados nos próximos 15 anos que reúnem três dimensões do desenvolvimento sustentável: econômica, ambiental e social. O foco é atingir objetivos em escala global, envolvendo também países já desenvolvidos, em busca de novos padrões de produção de consumo. A parceria significa o reconhecimento do trabalho que o Instituto desenvolve ao longo desses 10 anos com seus visitantes, funcionários e comunidade ao redor. Isso acontece por meio de atividades educativas, tal como, o Laboratório Inhotim; ações ambientais, tal como o processo de compostagem realizado diariamente; além de parcerias que contemplam estratégias de sensibilização global para os problemas da mudança climática, como a firmada com o Banco Interamericano de Desenvolvimento (BID) ${ }^{13}$.

\footnotetext{
${ }^{13}$ BID é uma organização financeira internacional, com sede em Washington (EUA), criada em 1959, com o propósito de financiar projetos viáveis de desenvolvimento econômico, social e institucional. Promove a integração comercial regional na área da América Latina e o Caribe. Unidas. Disponível em < https://www.iadb.org/es/acerca-del-bid/perspectiva-general>. Acesso em: 23 out. de 2019.
} 
Ações permanentes, como o Viveiro Educador, voltadas para a manutenção do acervo botânico, pesquisa científica, conservação e educação ambiental. Uma porção selecionada de toda a coleção botânica (Figura 21) está representada nos jardins do espaço que ocupa uma área de aproximadamente $25 \mathrm{mil} \mathrm{m}^{2}$ :

No Viveiro Educador, a informação e a prática contribuem para a construção do conhecimento, a sensibilização ambiental e a popularização da ciência de forma lúdica e interativa. $\mathrm{O}$ caminho entre espécies de plantas do mundo todo permite ao visitante o contato com experiências diferenciadas que envolvem o reino vegetal, seus diferentes grupos e formas variadas. Podem ser observadas extravagantes plantas carnívoras, diversas espécies de orquídeas, plantas medicinais e aromáticas, plantas aquáticas de exótica beleza, palmeiras e uma diversidade espetacular de araceae, como a excêntrica florcadáver (Amorphophallus titanum). (INSTITUTO INHOTIM, 2019).

O Instituto Inhotim promove e propicia oportunidades para que sua comunidade reflita sobre as questões ambientais em um espaço natural - um lugar que num passado não tão distante fora destruído pela extração de minérios. Nesse contexto, Inhotim e Brumadinho são testemunhas dos estragos provocados pela ação do homem:

\footnotetext{
Muito cedo se percebeu a importância da conservação como a forma mais adequada para os homens continuarem existindo (em memória). Muito cedo também se percebeu que a destruição dos objetos pelas guerras e pela desvalorização dos ecossistemas é capaz de eliminar e apagar a memória da humanidade (SANTOS, 2000, p. 17).
}

Inhotim é considerado uma Organização de Sociedade Civil de Interesse Público (OSCIP) de grande importância em diversas áreas de interlocução com sua comunidade. Com atuação multidisciplinar, se consolida a cada dia como um agente propulsor de desenvolvimento humano sustentável (INSTITUTO INHOTIM, 2019). Sob esse aspecto sua localização contribui para essa consciência sustentável. Ele está localizado numa região rica em recursos hídricos: lagos e nascentes são protegidos pelos remanescentes florestais mantidos intactos pelo Instituto. Há também uma Reserva Particular do Patrimônio Natural, a RPPN Inhotim. Poços artesianos e reservatórios de água para irrigação são utilizados para o abastecimento do parque. E um sistema próprio composto por fossas sépticas e estações de tratamento biológicas é usado para o tratamento dos efluentes gerados. Com o objetivo de manter a qualidade dos recursos hídricos e do tratamento dos efluentes, são realizadas, periodicamente, coletas de amostras de águas e efluentes para monitoramento físico-químico. (INSTITUTO INHOTIM, 2019). Nesse ponto, o acesso a essas informações enriquecem a presente pesquisa, uma vez que se trata a relevância do espelho d'água no Instituto. 
Já o Jardim Botânico Inhotim (JBI) (Figura 21) mantém, propaga e propicia estudos com as espécies botânicas de seu acervo de aproximadamente 5.000 espécies, representando mais de $28 \%$ das famílias botânicas conhecidas no planeta. A ênfase do trabalho é dada às espécies ameaçadas, à conservação de recursos genéticos e à disposição das espécies de forma paisagística. A introdução de espécies pouco conhecidas de forma paisagística é uma das estratégias utilizadas para divulgar e sensibilizar os visitantes sobre a importância da biodiversidade vegetal para a sobrevivência humana.

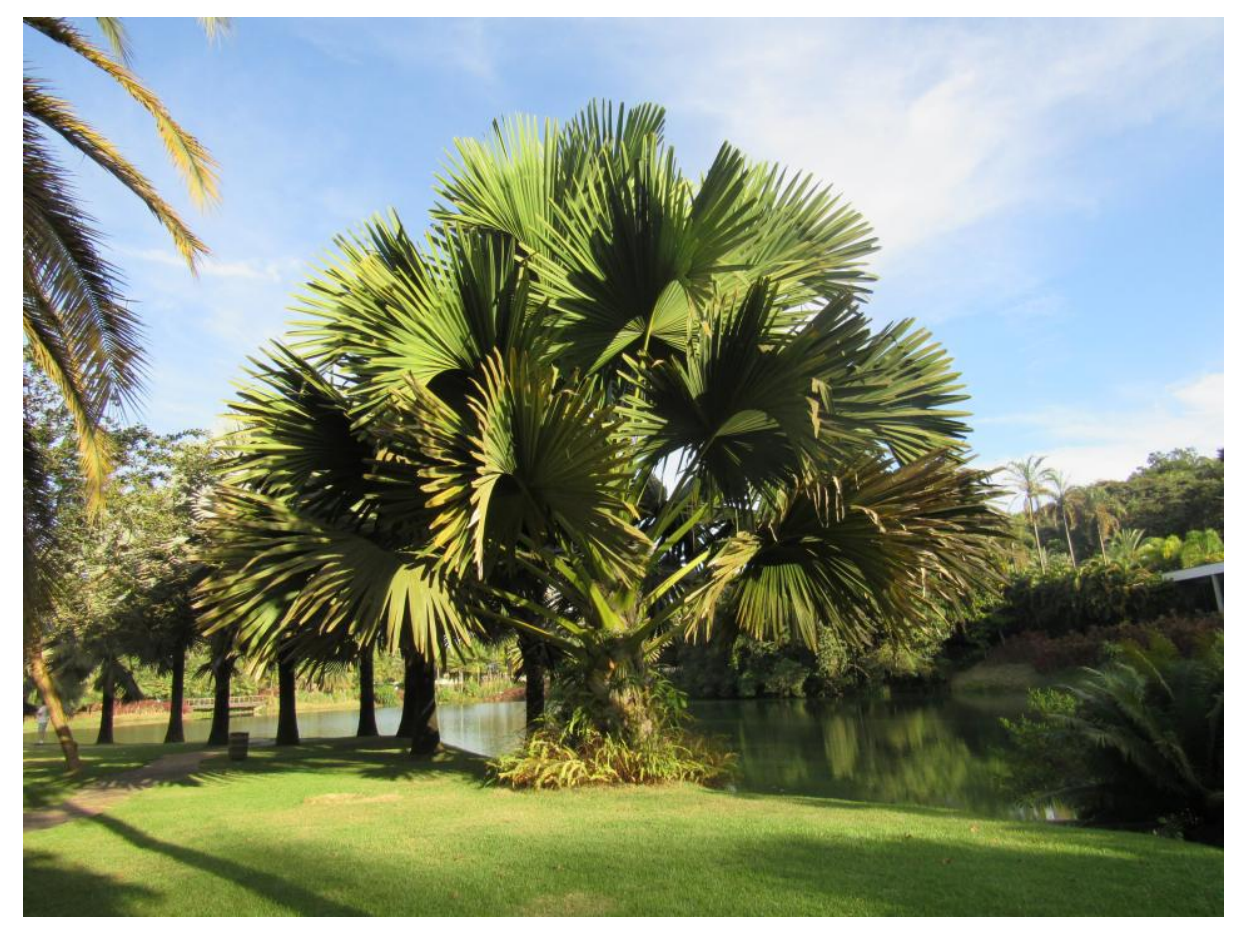

Figura 21. Jardim Botânico Inhotim. Fonte: acervo da autora.

Após a descrição das ações e aspectos que inserem o Instituto de Arte Inhotim como um ecomuseu, reforça-se o conceito criado pelo Internacional Council of Museums (ICOM), pela a Carta de Santiago (1972) e pelo Subcomitê de Museologia para a América Latina e o Caribe (ICOFOM-LAM): "os museus hoje devem estar, antes de tudo, a serviço de toda a humanidade e que a principal meta é a educação e a transmissão de informações e de conhecimento por todos os meios disponíveis" ${ }^{14}$.

A partir dessa reflexão sobre o papel de um ecomuseu e suas potencialidades, como difusor e mantenedor da natureza percebe-se que Inhotim incorpora recursos; ele

\footnotetext{
${ }^{14}$ Resolução n.1. Conferência geral dos museus, realizada em Grenoble, França, 10 set. 1971, antes da Conferência de Santiago.
} 
aporta educação e tecnologia e, estrutura a prática com a teoria. Compactua com ideais comuns e com a atuação integrada de profissionais qualificados, com propostas éticas definidas junto ao corpo social. Inhotim é um museu para todas as idades, com projetos escolares para as escolas municipais e estaduais, além de compor alternativas para a ação educativa de base em comunidades com menos recursos. Assim, tais iniciativas caracterizam ações que buscam a preservação de recursos naturais, correspondendo à proposta de desenvolvimento sustentável, a partir dos indicativos do ecoturismo. Como explica Lavelock (2006, p. 17):

O desenvolvimento sustentável é um alvo móvel. Representa o esforço constante em equilibrar e integrar os três pilares do bem-estar social, prosperidade econômica e proteção ambiental em benefício das gerações atuais e futuras.

Desse modo, considera-se que conviver com a arte, assim como aprender a respeitar e a apreciar o meio ambiente natural são importantes iniciativas, num processo cultural, dentro das relações sociais dentro de uma instituição como Inhotim. Toda ação que permita ou estimule o encontro da sensibilidade humana com o da arte, sem dúvida, é valida.

\subsection{Conceitos}

Inhotim é um destino: é um lugar posto no mapa que está em permanente transformação e local para romper a solidão do individualismo - aquela espécie de solidão que impede os indivíduos de compartilhar. O Instituto convoca à reflexão sobre em qual momento da humanidade perde-se o sentido de interação entre a paisagem e a beleza. Essa integração é o sonho de Bernardo Paz expresso em Através: Inhotim (2008) - catálogo do acevo. Para ele, o sonho é recuperar o diálogo, as conexões e a interdependência entre os humanos e o entorno; é a busca da síntese entre cultura e natureza. Assim sendo, as intenções e a dinâmica de Inhotim se prestam a presente pesquisa sobre arte e natureza através do espelho e do espelho d'água. Esta investigação é sobre a travessia do espelho em Inhotim - algo que remete à história de Alice, através do espelho, uma metáfora que possibilite a inserção no mundo dos reflexos, "uma névoa prateada e luminosa começava se desfazer." (CARROLL, 2010, p. 165), especialmente se evoca-se a luz, o nitrato de prata (material do que é feito o espelho) e nos reflexos nos espelhos d’água. 
O nome Inhotim tem diversas explicações. Porém, a mais conhecida envolve Sir Timothy, morador da área ocupada hoje pelo Instituto. O pronome "Sir", traduzido para o português como "Senhor", era muitas vezes falado como "Nho". Assim, "Sir Timothy" se transformou em "Nho Tim”. Vale lembrar, que ao acessar o site, um convite é feito aos visitantes virtuais para que contribuam na construção desse processo de recuperação e de resgate da memória e da oralidade sobre o significado do nome Inhotim. No passado, o lugar é destruído pela ação das mineradoras. Contudo, a região continua servindo de caminho para os grandes núcleos de mineração. No presente, Inhotim desenvolve ações em prol da conservação, sendo uma instituição comprometida com o desenvolvimento social, cultural e ambiental da comunidade onde está inserida ${ }^{15}$. Como já citado, em Inhotim estão um jardim botânico e um museu a céu aberto de arte contemporânea, localizado no município de Brumadinho em meio às montanhas mineiras. O caminho até Inhotim é uma espécie de travessia, uma experiência estética, em meio às montanhas a $60 \mathrm{~km}$ de Belo Horizonte e a $580 \mathrm{~km}$ de São Paulo, uma espécie de trilha.

Eu veria o jardim muito melhor, disse Alice para si mesma, se pudesse chegar ao topo daquele morro, e cá está uma trilha que leva direto pra lá... pelo menos - não, não tão direto... (depois de seguir a trilha por alguns metros e dar várias viradas bruscas), mas suponho que por fim chega lá. (CARROLL, 2010, p.175).

Depois de viradas bruscas, como na descrição de Alice, se chega a esse lugar tão peculiar. A propriedade de Inhotim é do empresário do setor ferrífero e siderúrgico Bernardo Paz. Até meados da década de 1990, Bernardo Paz é colecionador de obras de arte moderna. Ao longo de uma década, a coleção teve um aumento considerável e passa a ser integrada por obras de arte contemporâneas - um acervo marcado por aquisições de trabalhos-chave, tais como, os de Cildo Meireles, os de Miguel Rio Branco e os de Paul McCarthy. De acordo com Fernando Serapião (2015), na obra Inhotim: arquitetura, arte e paisagem, a concepção de criação de um museu-jardim foi motivada pelo artista Antônio José de Barros de Carvalho e Melo Mourão, mais conhecido como Tunga.

\footnotetext{
${ }^{15}$ Inhotim está inserido no bioma Mata Atlântica com encraves de cerrado - dois biomas com alta riqueza biológica. Além das plantas exóticas (provenientes de fora da flora original local), o Instituto abriga um relevante acervo botânico com milhares de espécies nativas, incluindo plantas raras, endêmicas e ameaçadas de extinção. Disponível em: http://www.inhotim.org.br/blog/tag/meio-ambiente/. Acesso em: 25 jun. 2018.
} 
O Instituto Inhotim começou a ser idealizado pelo empresário mineiro Bernardo de Mello Paz a partir de meados da década de 1980. A propriedade privada se transformou com o tempo, tornando-se um lugar singular, com um dos mais relevantes acervos de arte contemporânea do mundo e uma coleção botânica que reúne espécies raras e de todos os continentes. Os acervos são mobilizados para o desenvolvimento de atividades educativas e sociais para públicos de faixas etárias distintas. O Inhotim, uma OSCIP (Organização da Sociedade Civil de Interesse Público), tem construído ainda diversas áreas de interlocução com a comunidade de seu entorno. Com atuação multidisciplinar, o Inhotim se consolida, a cada dia, como um agente propulsor do desenvolvimento humano sustentável (INSTITUTO INHOTIM, 2019).

No Instituto de Arte Contemporânea de Inhotim existe a intervenção arquitetônica de galerias, sites specifics, jardim botânico e espelhos d'água naturais e artificiais que se adequam perfeitamente ao entorno, criando um diálogo, nesse contexto de continuidade visual entre arte e paisagem. Nesse lugar, abrigam-se 22 galerias que parecem irromper espontaneamente em meio à mata, interferindo direta e visivelmente como um corte abrupto na paisagem e no horizonte. Em outras palavras, algumas das galerias têm como proposta a ruptura com o verde da paisagem e causam um impacto direto no público. Esse percurso convoca à desaceleração do ritmo de vida da cidade. A combinação entre natureza, obras e a relação intermitente entre cada galeria, pavilhão, propõe uma experiência única. A escolha por Inhotim deve-se às características particulares que favorecem ao espectador a relação espacial com a arte, o artista e a exibição das obras, diferentemente dos museus convencionais no que se refere ao tempo, tamanho, forma e espaço.

A ideia, segundo a curadoria, "é construir um lugar de convivência multicultural e de várias gerações, sem nenhuma diferenciação entre local e internacional, onde a arte das culturas da Europa, Ásia e das Américas possa viver lado a lado, onde o conteúdo e a vivência da arte - e não as relativas realizações individuais - são determinantes" (SHUWARTZMAN, 2008, p.28). Por sua biodiversidade e variedade artística, Inhotim é um espaço que pode ser visitado por qualquer pessoa, mesmo aquelas que não se interessam avidamente por arte. Isto porque sua localização, as matas e as trilhas entre uma galeria e outra por si só já proporcionam passeio e descontração ao público. Inhotim mantém-se ainda em constante transformação desde sua inauguração: além das galerias e jardins externos, tem também restaurante, cafeteria e quiosques distribuídos em lugares específicos. 


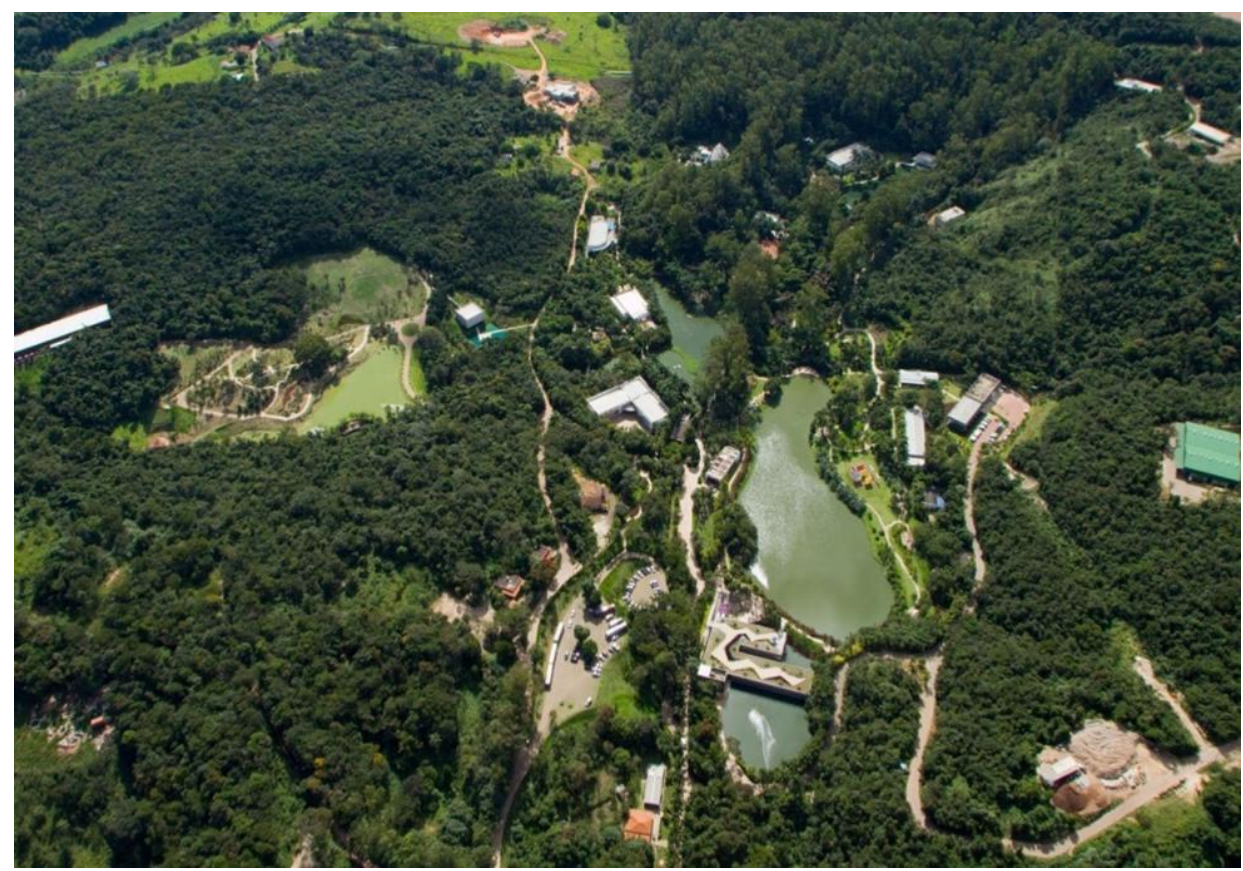

Figura 22. Vista aérea de Inhotim.

Fonte: https://www.pinterest.pt/pin/42432421459432571/. Acesso em: 29 de jun. 2018.

Contudo, Inhotim (Fig. 22) não é o único centro de arte contemporânea com essa dimensão gigantesca. Internacionalmente, existe esse modelo em outros formatos. São outros museus que direcionam ao formato de museu ao céu aberto em meio à natureza.

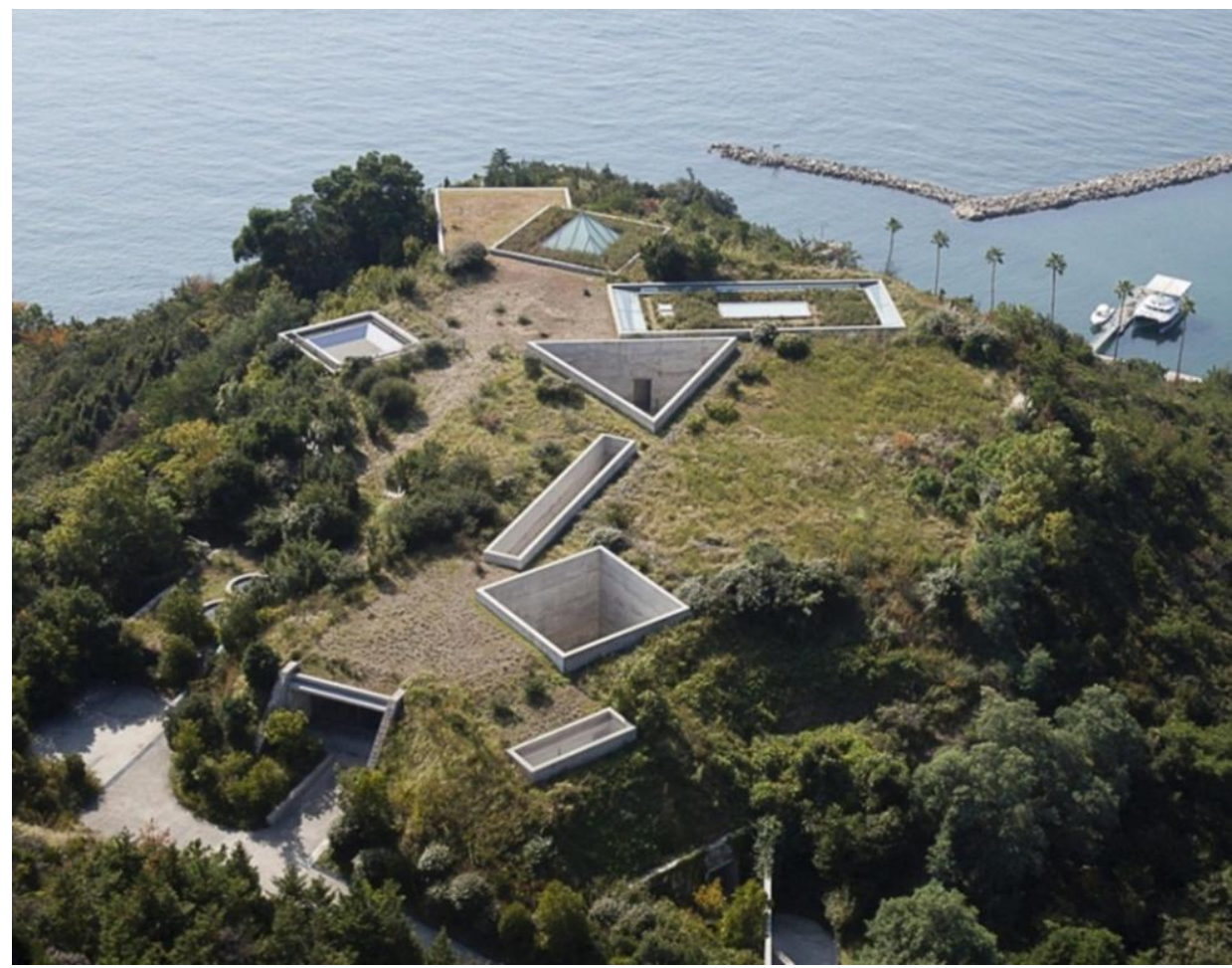

Figura 23. Benesse Art Site Naoshima, 2018 (vista aérea).

Fonte: http://benesse-artsite.jp/en/art/chichu.html. Acesso em: 27 jun. 2018. 
O Benesse Art Site Naoshima (Figura 23) é o nome coletivo de todas as atividades relacionadas à arte conduzidas pela Benesse Holdings, Inc. e Fundação Fukutake, nas ilhas de Naoshima e Teshima, na província de Kagawa e na ilha de Inujima, na província de Okayamano (Japão). O espaço é idealizado pela iniciativa dois homens: Tetsuhiko Fukutake, o presidente-fundador da Fukutake Publishing, e Chikatsugu Miyake, então prefeito de Naoshima. O objetivo é criar espaços que tragam a arte contemporânea e a arquitetura em comunhão com a natureza intocada do Mar de Seto, uma paisagem com um rico espaço cultural e histórico. Através dos contatos entre arte e natureza, cenários e habitantes da região do Mar de Seto, os visitantes refletem sobre o significado do lema de Benesse: "bem-estar". Na Benesse Art Site Naoshima, promove-se uma relação de crescimento mútuo entre a arte e a região, contribuindo positivamente para as comunidades locais. Na Benesse Art Site, nasce, ainda, o Naoshima Internacional Campsite, em 1989. Em seguida, abre a Benesse House (1992), um estabelecimento que oferece quartos de hotéis e espaços dedicados à exibição de arte contemporânea. Os habitantes da ilha colocam a arte contemporânea no centro de seu interesse.

Ambos, Benesse e Inhotim, têm o caráter de parque e reserva natural. As duas instituições têm ainda inúmeras esculturas a céu aberto e circundadas esculturas, arquiteturas e instalações. Os artistas produzem as obras especialmente para o local. Por sua vez, em Inhotim há diversas manifestações e proposições artísticas distribuídas entre esculturas, instalações, fotografias, vídeos etc. A Fundação Benesse não tem um acervo oriundo de uma única coleção, assim como em Inhotim.

\subsection{Processos criativos}

A ideia inicial da presente pesquisa surge da intenção de investigar o espelho e seus desdobramentos nas obras de artistas contemporâneos brasileiros. A partir dessa primeira escolha, acontecem visitas técnicas a Inhotim em maio de 2018 e em fevereiro de 2019. As visitas, por sua vez, motivam a seleção do recorte. Nessas visitas, torna-se possível o mapeamento de obras que apresentam, de algum modo, o artifício espelho como tema central. Contudo, num primeiro momento, esse mapeamento mostra-se vasto. Diante da profusão de obras e artistas, realiza-se um recorte que viabiliza o estudo: parte-se para a seleção de obras que dialogam diretamente com o artificio espelho, sejam naturais ou artificiais e, ao mesmo tempo, expõem o reflexo em leituras e em escrituras específicas. 
Acontece, então, a primeira seleção, buscando artistas que apresentem o espelho e/ou reflexos como "conteúdo" da obra de arte, visando especialmente os sentidos e a experiência como parte constitutiva. Essas obras estão sintonizadas com os procedimentos estético-artísticos que mesclam matérias de expressão e sentidos e que rejeitem uma visão pré-estabelecida da realidade. Essas questões estão relacionadas ao sujeito pós-moderno e à sua identidade fragmentada (CHAUÍ, 2006). Sendo assim, a seleção desses artistas, em cujas obras exploram, sobretudo, a fantasia em confrontação com a realidade dominante, como meio de interromper a atividade do público, descentralizando sua percepção e induzindo a autorreflexão do espelho refletido.

Dessa seleção, são mapeadas oito obras/galerias do museu: galeria Adriana Varejão; Valeska Soares, Folly; Yayoi Kusama, Jardim de Narciso; Cristina Iglesias, Vegetation room Inhotim; Olafur Eliasson, Viewing Machine e Dan Grahan, Bisected triangle/interior curve.

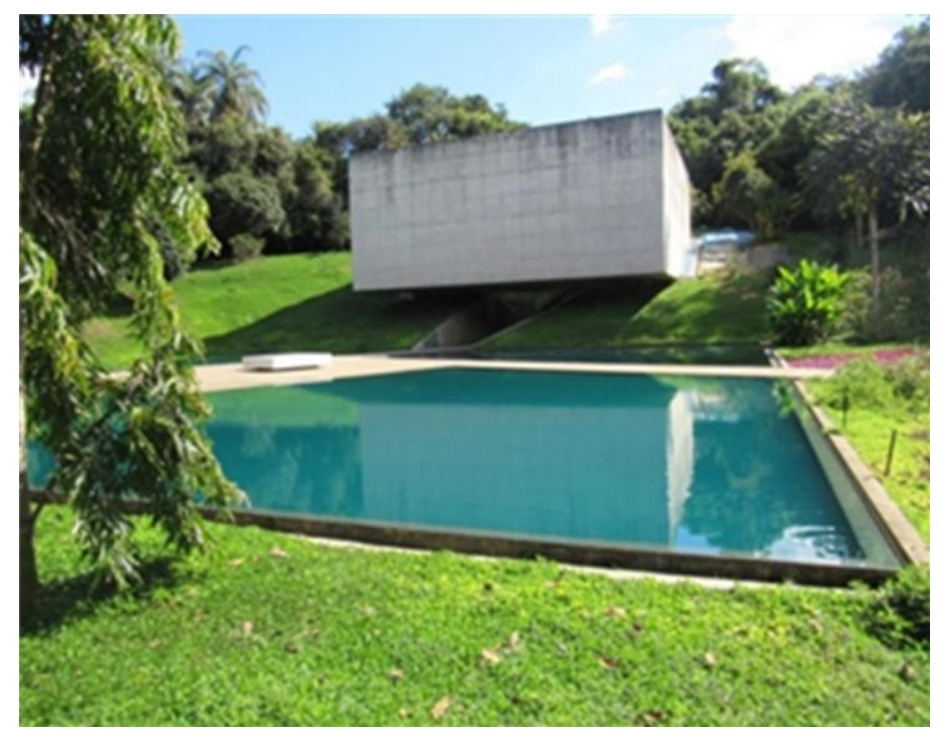

Figura 24. Galeria Adriana Varejão. (Vista externa) Instituto Inhotim. Brumadinho, Minas Gerais. Fonte: Acervo da autora.

Inicialmente, apresenta-se a Galeria de Adriana Varejão (Fig. 24). Nessa galeria, a artista participa do seu desenvolvimento e torna-se coautora. No espaço, notam-se, em frente ao lago artificial, os reflexos da monumental arquitetura. Assim, a estrutura do reflexo desenvolve quase uma saga aos olhos através da percepção do visitante, mostrando uma estética de dualidades e autoduplicação como visceral resposta à experiência estética. Esse efeito produz experiências transformadoras e performativas no espectador. 
Em seguida, a obra Vegetation room Inhotim, 2010, de Cristina Iglesias (Fig. 25) é pontuada. Nessa investigação do percurso dos reflexos, a artista espanhola constrói lugares, configurados pela ficção. Ao pensar a escultura, Iglesias fixa um percurso estético a partir da literatura passando pela ficção científica. Em meio ao jardim botânico em Inhotim se encontra um labirinto espelhado, formado por corredores revestidos de baixos relevos com motivos florais, formando séries repetitivas revestidas por toda a parede interna. A artista convida o público a passear pela obra em trajetos já estabelecidos. A decoração interna se repete inúmeras vezes. O mesmo tipo de flores esboça, desenha e filtra a luz solar, como parte da mimese.

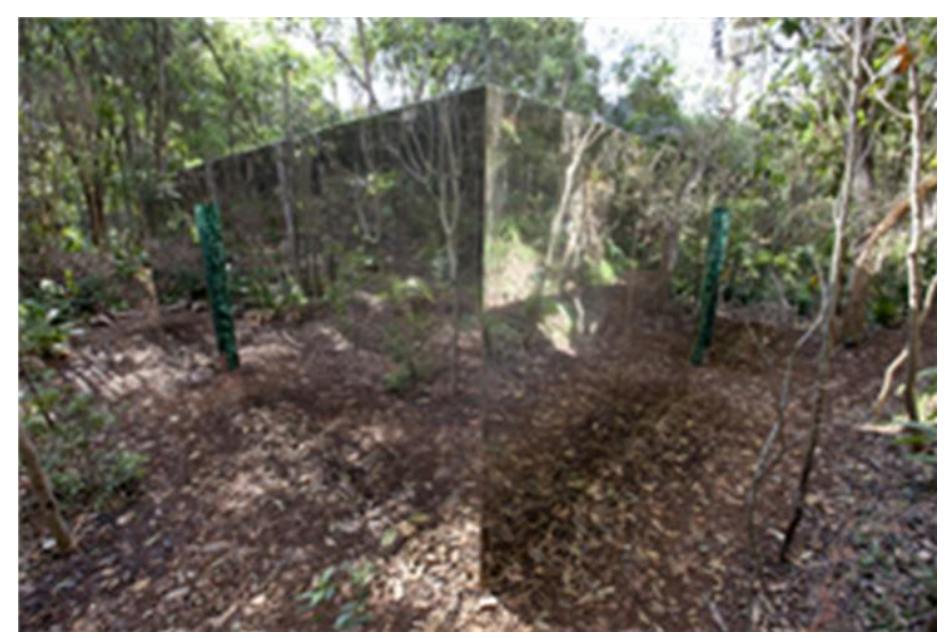

Figura 25. Cristina Iglesias, Vegetation room Inhotim, 2010. Instituto Inhotim de Arte Contemporânea, Brumadinho, Minas Gerais. Fonte: Acervo do autor.

A obra Viewing Machine, 2002-2008, Olafur Eliasson (Figuras 26 e 27) é uma das mapeadas, apesar de não ser a selecionada para um estudo mais aprofundado. Destaca-se que Eliasson é um dos principais artistas contemporâneos que trabalham com o tema "espelho". Para o artista, o espelho é uma reflexão sobre o si e sobre outro dentro do espaço. Os jogos de espelhos e a criação de ambientes caleidoscópicos com cores hiper-reais transportam o espectador para mundos paralelos, como o de Alice. O espelho cria um portal para a reflexão; aparentemente, parece nítido e destituído de ambiguidades, pura ilusão. Na obra de Eliasson, o espelho é usado como poética, questionando o caráter de verdade em seu reflexo. Assim, o artista usa o espelho, dentro do caleidoscópio, o espaço refletido, a arquitetura e as pessoas, aproximando o mundo real do irreal, na medida em que se dissolvem as polaridades entre o artificial e o natural. Segundo, o site de Inhotim: 
Sua obra baseia-se nos princípios de funcionamento do caleidoscópio, gerando um efeito obtido pelo reflexo da luz em seis espelhos que formam um tubo hexagonal. Na etimologia da palavra caleidoscópio, estão as palavras gregas kalos (belo), eidos (forma) e scopos (observador) "observador de belas formas", algo que o artista reinterpreta no título da obra: "máquina de ver". O visitante manuseia a máquina e observa seu entorno.

Sob o efeito de sobreposições cria-se uma miríade de formas. A escultura funciona como uma ferramenta, uma espécie de prótese de extensão que modifica a visão do mundo, proporcionando um prazer lúdico e até mesmo o prazer de sentir e perceber a si pelas lentes replicantes.

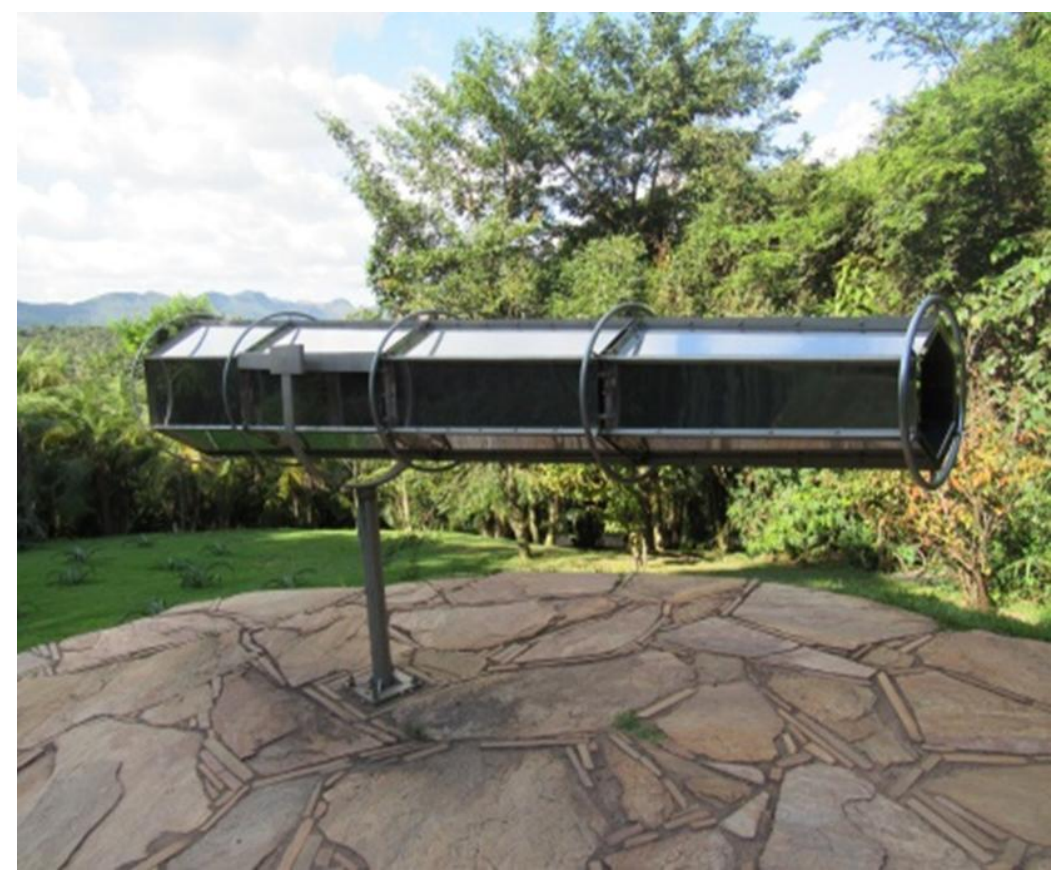

Figura 26. Olafur Eliasson. Viewing Machine, 2002- 2008. Aço inoxidável e metal. Inhotim-MG. Fonte: acervo da autora.

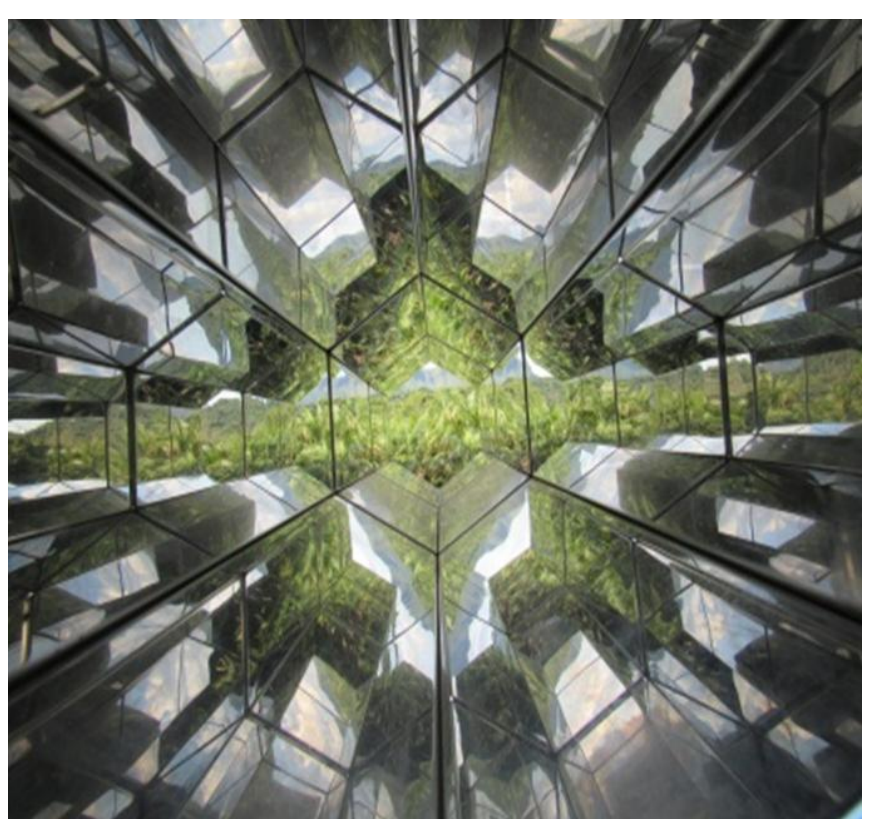

Figura 27. Olafur Eliasson. Viewing Machine, 2002- 2008. Aço inoxidável e metal. Inhotim-MG. Fonte: Acervo crédito da autora. 
A produção artística de Dan Graham data do início dos anos 1960. Desde, então, vem desenvolvendo uma consistente obra, que inclui a fotografia, a escultura, a performance, a instalação e vídeos, passando pelos quadrinhos e os desenhos. Graham, com a obra Bisected triangle, interior curve, 2002 (Figura28), instalada em Inhotim, trata de questões do espelho, baseadas na percepção e na reação do visitante, individualmente e coletivamente. A duração e a atenção são essenciais para o intérprete e a audiência. Através do uso do espelho, o público/performer é capaz de perceber-se instantaneamente como uma massa (como uma unidade). O público se vê refletido no espelho. Ele explora pontos de vista invertidos ou inusitados sobre ações ocorridas no espaço e tempo presente. Essa instalação transita no campo da arquitetura, destacando o estudo da habitação popular americana pós-II Guerra Mundial. A partir de 1987, Graham produzi pavilhões que se colocam na linha tênue entre a arquitetura e a escultura, discutindo não só a questão da habitação e do urbanismo nas grandes cidades como também o lugar da arte e sua relação com o espectador.

Seus pavilhões têm como material constitutivo básico vidros - quase sempre com espelhamentos -, seguros por bordas de metal. A partir de formas simples, muitas delas curvas, os espelhos provocam distorções em seus reflexos, assim como sobrepõem camadas de profundidade, causando confusão na percepção do espaço ao redor, misturando o dentro e o fora. $\mathrm{O}$ fato de os pavilhões estarem muitas vezes instalados no exterior dos prédios faz com que o trabalho de Graham reflita sobre as ligações entre a arquitetura e o seu espaço circundante, o que se evidencia em Inhotim, onde o diálogo entre arquitetura-escultura e paisagem-jardim aparece com ênfase. (INSTITUTO INHOTIM, 2019).

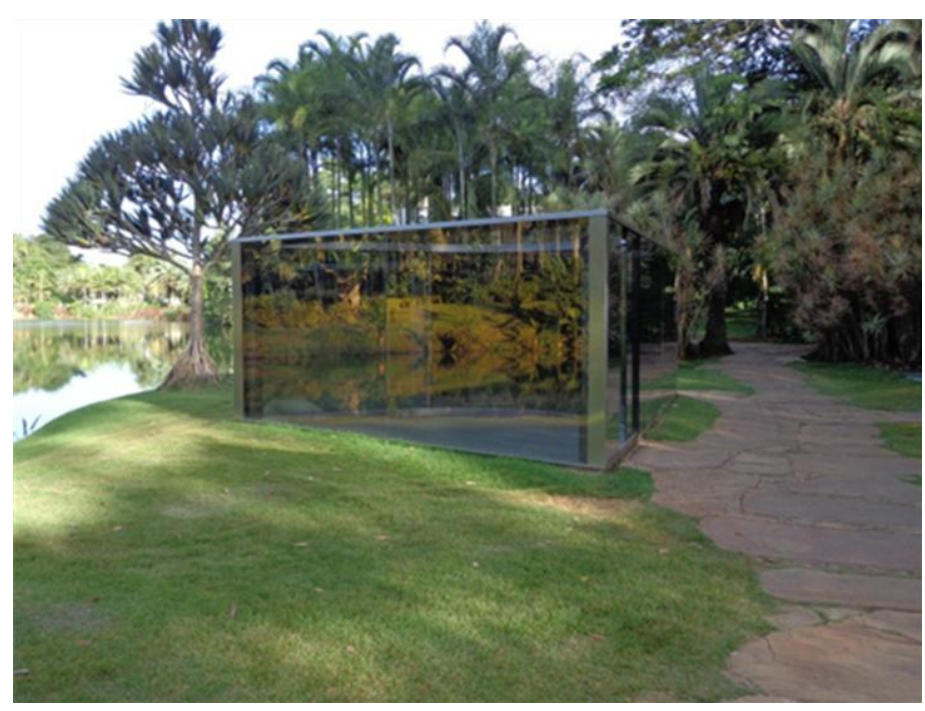

Figura 28. Dan Graham. Bisected triangle, interior curve, 2002, Inhotim, MG. Fonte: acervo da autora. 
Para Graham, o espelho é participante da sua obra como elemento fundamental da construção, uma instalação feita de aço e vidros espelhados e replicantes que produzem reflexos e distorções através de um espelho côncavo e outro convexo.

A quinta obra, presente no levantamento, é De lama lâmina, 2009, de Matthew Barney (Figura 29). Nessa instalação, o visitante caminha por uma trilha de terra, percorrendo mata adentro. A proposta é que ao caminhar se faça essa transição de lugares distintos, onde o homem se torna o estranho. Quando o visitante de Inhotim chega ao local da obra é confrontado com a monumentalidade da geodésica de ferro e vidro, bem como a presença do trator e da árvore. A instalação destoa da mata fechada, isto porque apresenta materiais e significados distintos que envolvem a racionalidade, cálculos matemáticos e projeção estrutural. A obra mostra como a máquina está dominando a natureza numa relação quase brutal. O ambiente construído faz com que a imagem seja refletida nas paredes.
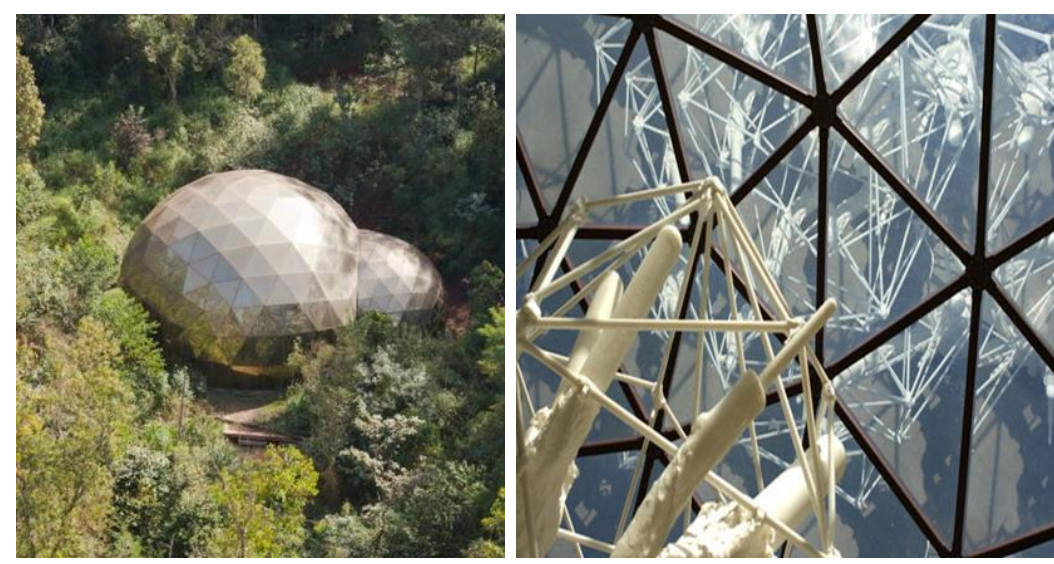

Figura 29. Mathews Barney, De lama lâmina, 2009. Lado de fora à esquerda, detalhe do lado interno à direita. Fonte:

<http://www.lab404.ufba.br/?p=1860>. Acesso em: 26 out. 2019.

Segundo o artista, a obra se refere à cultura africana, representando a luta de Ogum, orixá do ferro e da guerra, contra Ossain, orixá da natureza. Trata sobre o eterno conflito natureza versus civilização, reencenado pelos orixás. O domo geodésico é projetado exclusivamente para abrigar a instalação, sob a supervisão do artista. É uma barreira que abriga a obra de arte no parque-jardim, separando o universo mágico da obra do mundo exterior. Os vidros da estrutura refletem o trator e a árvore de modo a multiplicar a imagem congelada dessa metáfora de Ogum e Ossain, replicando-a indiscriminadamente. É criada uma virtualidade que sobressai à paisagem externa em infinitos cacos fantasmagóricos que pairam sobre a mata. $\mathrm{O}$ espectador tem a sensação 
de estar dentro de um caleidoscópio, cujas formas projetadas criam outra dimensão, extraindo a singularidade da instalação, conferindo-lhe esse efeito de espelho e ilusão.

A obra Narcissus Garden, 2009, Yayoi Kusama (Figura 30) é uma versão adaptada da instalação datada de 1966, apresentada extraoficialmente na $33^{\text {a }}$ Bienal de Veneza. Na ocasião, Kusama instala-se clandestinamente, sobre o gramado em meio aos pavilhões 1.500 bolas espelhadas de inox que são vendidas aos transeuntes por dois dólares cada. A placa colocada entre as esferas dizia: "seu Narciso à venda"; essa mensagem é uma crítica ao sistema de repetição e mercantilização das artes. Ao questionar a vaidade humana, Kusama reflete sobre o mundo do consumo e sobre a sedução da era do consumismo. A artista tenta transformar o real em representação falsa. Quanto mais se investe no "eu" e quanto mais se faz dele objeto de atenção e de interpretação, mais aumentam as incertezas e a interrogação. O "eu" se torna um espelho vazio. A beleza narcísica se processa por meio de troca financeira, troca-se um rosto, um corpo, os cabelos, em busca de padrões de beleza e medidas impossíveis. A precariedade biológica do corpo humano é uma crítica sobre a desfiguração do corpo, criando desestabilização ou flutuação da "psi”, comparável à flutuação monetária ou à flutuação da opinião pública. ( LIPOVETSKY,2006, p.37). Por toda a parte, se vê a tendência ao desregramento de si, indivíduos entregues a vertigem de si próprios entregues ao supermercado contemporâneo dos modos de vida. À medida que se amplia o princípio de pleno poder sobre a direção da própria vida, as manifestações de dependência e de impotência subjetivas se desenvolvem num ritmo crescente. Isso remete à cena pós-moderna do consumo. É Narciso libertado e, simultaneamente, Narciso acorrentado (LIPOVETSKY, 2006).

Na versão de Inhotim, por ser um trabalho calcado na repetição e acumulação, a artista utiliza os espelhos que para a reflexão e a multiplicação infinitamente. As esferas em metal reflexivo, colocadas sobre o lago movimentam-se conforme os intempéries climáticas ou pela ação do homem. Essa dança das esferas são determinadas pela ação e pela delimitação das vegetação no espelho d'água. A imagem do espectador é projetada e multiplicada nas esferas côncavas, assim como na obra de Soares, Folly. Conforme o texto crítico de apresentação da obra no site Inhotim, constata-se:

Na versão de Inhotim, 500 esferas de aço inoxidável flutuam sobre o espelho d'água do Centro Educativo Burle Marx, criando formas que se diluem e se condensam de acordo com o vento e outros fatores externos e refletindo a paisagem de céu, água e vegetação, além do próprio espectador, criando, nas palavras da artista, "um tapete cinético" (INSTITUTO INHOTIM, 2019). 
A esfera convexa espelhada de Narcissus Garden tem a propriedade de prolongar o campo de visão. Afinal nas esferas, tudo reflete: o entorno, o corpo e o lago. Desse modo, elas auxiliam o sujeito na sua constituição identitária. As esferas funcionam como uma "prótese do olhar", pois a imagem refletida na esfera intensifica e prolonga a cena e a profundidade dos planos representados. A distorção da imagem real e a criação da imagem virtual promovem uma imagem circular, revelando uma perda da unidade do reflexo do corpo. A sedução proporcionada pelo espelho é compelido por uma súbita atração e como consequência o narcisismo é provocado. Enfim, "seu narciso a venda", reflete e estabelece a relação entre o público e privado. O reflexo de si e do outro é multiplicado por meio do "espelho público", no qual é comprado e vendido por um valor estipulado de troca econômica, processo que funciona à base da sedução.

Evocando o mito de Narciso, que se encanta pela própria imagem projetada na superfície da água, a obra constrói um enorme espelho, composto por centenas de pequenos espelhos convexos, que distorcem, fragmentam e, sobretudo, multiplicam a imagem daquele que a contempla - contemplando, assim, necessariamente a si próprio (INSTITUTO INHOTIM, 2019).

Kusama cria seu próprio Narciso, colocando-o em órbita flutuante, na liquefação da identidade rígida do eu e na suspensão da primazia do olhar do outro. Que o eusujeito se torne um espaço "flutuante" sem fixação ou referência, apenas self control, paixão do conhecimento de si (LIPOVETSKY, 2006, p. 40).

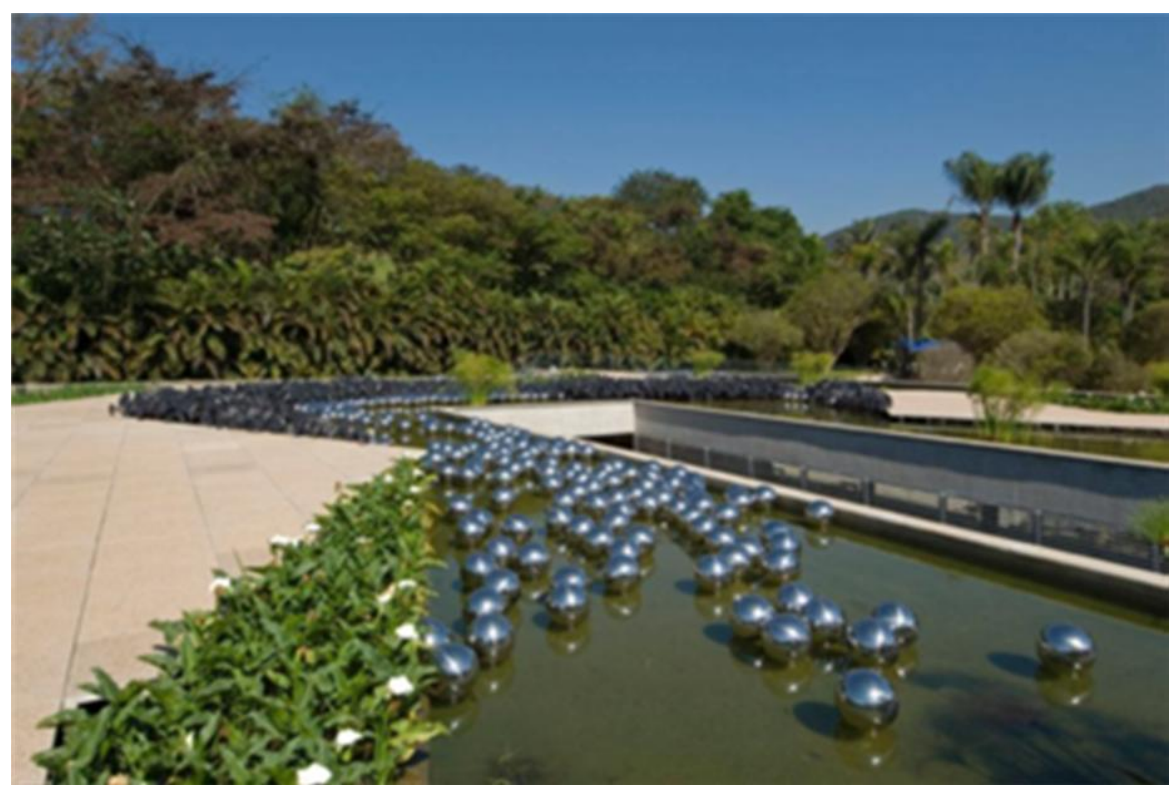

Figura 30. Yayoi Kusama, Jardim de Narciso, 500 esferas de aço inoxidável flutuam sobre um espelho d'água (detalhe da obra), 2009. Instituto Inhotim de Arte Contemporânea, Brumadinho, Minas Gerais. Fonte: Acervo crédito do autor. 
O argentino Jorge Macchi é o artista responsável pela obra Piscina, que como o título indica, convida os visitantes de Inhotim a um mergulho em plena visita. A obra de Macchi foi originalmente idealizada como uma aquarela, retratando um caderno com índice alfabético metamorfoseado em piscina. $\mathrm{O}$ artista é conhecido por fazer desenhos de objetos banais re-imaginados de forma surrealista. Desde o início de sua carreira, tem produzido de maneira bidimensional. Inhotim convida Macchi a transformar essa aquarela em uma instalação do tipo site specific. O que ocorre nessa instalação é a transposição de um desenho para uma obra de dimensões arquitetônicas. O trabalho funciona como uma piscina real, o que retira o visitante do papel de espectador e o convida a emergir na obra, como Narciso que mergulha no lago. Na pesquisa existe a inclusão desse artista por se tratar de um espelho d'água, que é o foco desta dissertação.

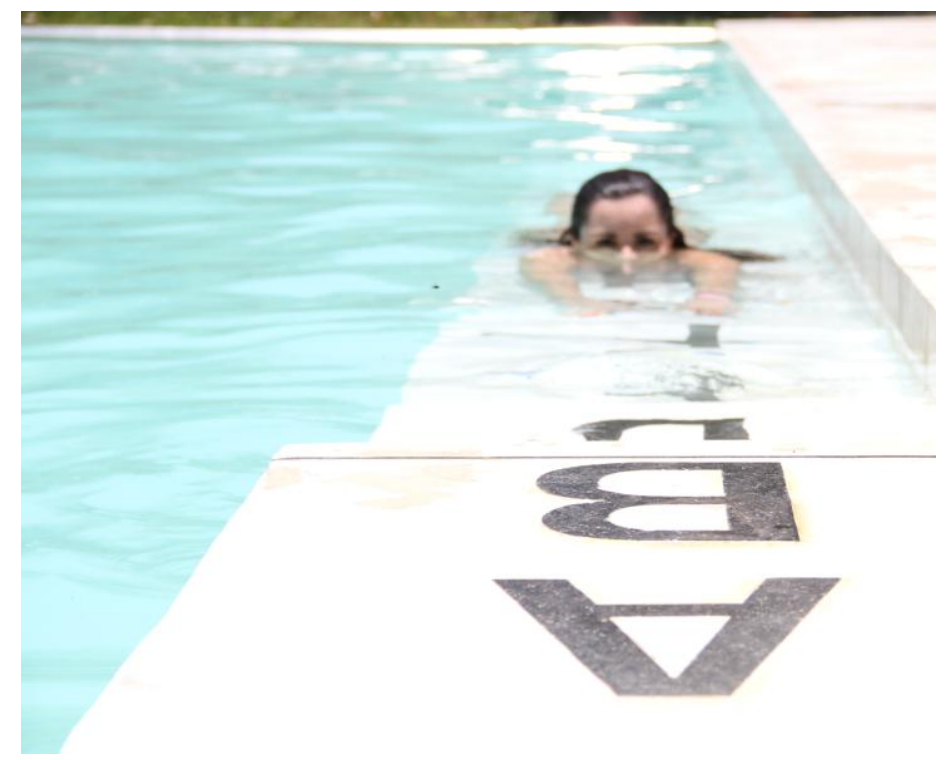

Figura 31. Jorge Macchi. Piscina, 2009. Hormigón blanco, piedra, água. 1200 x 1200 x $180 \mathrm{~cm}$. Fonte: Imagem cedida por Beatriz Alencar.

Durante o desenvolvimento e, sobretudo, após as considerações feitas pela orientadora Profa. Dra. Elza Ajzenberg, compreende-se que diante do grande número de artistas/obras que Inhotim abrange, essa escolha se faz grande demais para abarcar o intento e proporcionar, os resultados pretendidos. Assim, a partir desse momento é selecionada apenas uma artista com a finalidade de se consolidar a pesquisa com maior subsídio e profundidade. A obra que mais representa o foco desta pesquisa é Folly, de Valeska Soares. A artista tem vasto currículo desenvolvido sobre o assunto espelhos e reflexos. Pelo levantamento feito Valeska Soares desenvolve trabalhos em nove obras, 
ao longo de sua trajetória, na qual existem os temas espelho, reflexos, natureza e jardins. Após o exame de qualificação, outras questões se apresentam, apontando para um novo rumo nesta pesquisa. Ocorreu, então, a necessidade de um recorte maior para se aprofundar com maior excelência e esmero. O critério a ser desenvolvido como tema são os diálogos e as aproximações estéticas refletido nos espelhos da artista Valeska Soares em sua obra Folly, 2005-2009, dentro do espaço jardim botânico Inhotim. 


\section{Capítulo 3 Valeska Soares}

\subsection{Trajetória pessoal e artística}

Valeska Soares nasce em Belo Horizonte, Minas Gerais, Brasil, em 1957. Convive com a arte desde o berço, mais precisamente com o trabalho de Teresinha Soares, sua mãe, pintora e precursora das performances participativas no Brasil. Contudo, as artes plásticas não significam ser sua primeira opção: “a gente nunca quer ser o que a mãe da gente é, né?”, confessa a artista em entrevista (in MELLO, 2018). Então opta por arquitetura: "sinceramente foi a melhor coisa que poderia ter acontecido. A escola de artes plásticas era supercareta. A arquitetura me deu uma noção espacial e a condição de poder exercitar o que eu faço em várias linguagens diferentes", acrescenta (in MELLO, 2018).

No início dos anos 1990, conhece o colecionador Marcantonio Vilaça, fundador da galeria Fortes Vilaça, hoje Fortes D’Aloia \& Gabriel. Nesse momento, é convidada para fazer parte do quadro de artistas, ao lado de Ernesto Neto. Em 1992, muda-se para Nova York e conclui mestrado e doutorado em artes plásticas na Universidade de Nova York. Radicada em Clinton Hill, no Brooklyn, torna-se vizinha de Vik Muniz, onde reside até hoje. A artista vive e trabalha desde então fora do Brasil, embora tenha participado de várias Bienais de São Paulo, entre elas, as de 1994, 1998 e 2008. No exterior, participa da Bienal de Liverpool, no ano de 2004 e em 2005 na Bienal de Veneza com a obra Folly, que hoje está instalada em Inhotim - obra de análise desta pesquisa.

Segundo a própria Soares, uma boa chance para entender sua produção é a mostra na Estação Pinacoteca chamada Valeska Soares: Entrementes $2018^{16}$. Apesar de não ser uma retrospectiva no sentido formal, reúne obras de suas três décadas de produção. "Para fazer retrospectiva você tem que estar morto, fica parecendo que o trabalho tem começo, meio e fim, o que não é o meu caso." (in MELLO, 2018). Essa exposição na Estação Pinacoteca integra um programa de mostras que revisitam artistas com produções que emergem a partir dos anos de 1980 e que há muitas décadas desenvolvem uma obra complexa e volumosa, influenciando as gerações seguintes (VOLZ, 2018, p.61).

\footnotetext{
${ }^{16}$ A exposição Entrementes realizada na Estação Pinacoteca em São Paulo no ano de 2018. Trata-se do Projeto de Múltiplos, criado pela Pinacoteca, com o objetivo de angariar recursos para a instituição. Criado pela Pinacoteca em 2016, o projeto conta com a colaboração de Beatriz Milhares, Jac Leirner, Ana Maria Maiolino, Albano Afonso, Sofia Borges, Rochelle Cosi, Vik Muniz, Caio Reisewitz, Rosangela Rennó e Maria Bonomi, entre outros.
} 
$\mathrm{Na}$ exposição percebe-se que as esculturas, instalações e joias de Valeska Soares empregam diversos materiais, incluindo: espelhos refletivos, livros, móveis antigos, mármore esculpido, frascos de perfume, taças, copos e embalagens de bombons. Seus trabalhos são sustentados pelos conhecimentos em arquitetura e têm como ferramentas essenciais o minimalismo e o conceitualismo. Contrastando materiais industriais polidos com materiais mais efêmeros, a obra de Soares convida os espectadores a engajarem todos os cinco sentidos, evocando os temas poéticos e evasivos do desejo, da intimidade, da linguagem, da perda, da memória pessoal e da história coletiva através dos reflexos especulares.

\subsection{Metáforas do espelho}

Nas obras de Soares, estabelece-se uma narrativa em que o tempo é fragmentado e impreciso. Para ela, é um tempo que foge das narrativas do relógio cronológico. Um tempo próprio que notado na obra Vanishing point (Ponto de fuga) ${ }^{17}, 1998$.

O tempo é subjetivo e tecnicamente impreciso: é apenas uma maneira de sincronizar os eventos no espaço. Por exemplo, nós vamos nos encontrar para almoçar às duas horas. Mas sabe-se lá o que são "duas horas” significa. Moro sozinha, posso acordar a hora que quiser; dormir a hora que quiser e viajo muito, então acabo me perdendo nos fusos horários (SOARES apud HOFFMANN e TAXTER, 2018, p.29).

Em se tratando de tempo fragmentado ou tempo de contemplação, como o Tao, no qual se vivencia ao comtemplar um jardim japonês, como é discutido no Capitulo 1, a instalação Vanishing point (Figura 32), auxilia na compreensão dessa ideia de percepção e de contemplação a partir dos sentidos. Através do olfato, por exemplo, o aroma de flores que emanam dos tanques de água em formato labiríntico, o visitante caminha dentro da instalação transpõem-se a uma atmosfera que recria os jardins, como Inhotim ou Giverny. O tempo no jardim japonês é diferente. O visitante se conecta, se integra com o universo, com sua essência e com a sabedoria desse microcosmo construído.

\footnotetext{
$17 \mathrm{O}$ ponto de fuga é a referência no horizonte para fazer as linhas de um desenho e construir uma perspectiva. A palavra perspectiva tem origem no latim e significa "ver através de". Trata-se da representação bidimensional de algo tridimensional. A perspectiva ajuda o observador a enxergar aquela imagem no papel como se fosse um objeto ou paisagem real. Ela permite enxergar a altura, profundidade e largura dos elementos. As perspectivas com ponto de fuga são conhecidas como cônicas, mas existem outros tipos como a isométrica, cavaleira, militar, entre outras. Disponível em: <https://www.vivadecora.com.br/pro/estudante/ponto-de-fuga/>. Acesso em 02 set. 2019.
} 
O espelho, segundo Foucault (1967, p.80): “é uma utopia, uma vez que é um lugar sem lugar algum, vejo-me ali onde não estou, num lugar irreal, virtual, que está aberto do lado de lá da superfície; estou além, ali onde não estou, sou uma sombra que me dá visibilidade de mim mesmo, que me permite ver-me ali onde sou ausente". Semelhantemente, ao ato de caminhar pela instalação Vanishing point, 1998, que remete à ideia de quando se chega ao ponto de fuga, ele não existe mais, ele é um lugar teórico, porque quando se chega num ponto de fuga, ele se afasta; ele se torna na verdade um lugar não lugar.

\begin{abstract}
A obra Vanishing point por ser uma coisa instável, apresentando um conceito de jardim cuja paisagem sempre remete a construção de um lugar ideal. Como uma forma de analisar o desejo de uma maneira mais concreta, pois dentro das construções dos jardins existem todas essas ideias de alcançar a sabedoria e de representar o paraíso. No jardim também existe o fascínio que é aquilo em que em português chamamos de capricho. Vanishing point é um une folie, uma loucura, não tem nenhuma razão de existir, a não ser o próprio desejo de que exista (SOARES apud HERZOG, p.1, 2006).
\end{abstract}

Nesse ponto, Soares (2004) comenta: “o perfume constrói um volume virtual no espaço com o tempo, é tão forte que as pessoas não conseguem ficar lá dentro, ele começa a contaminar os outros andares". Conforme o curador Moacir dos Anjos (in SOARES, 2004), esses quinze tanques trazem a sensação imediata de certa repulsa gradual que o excesso de perfume provoca, simulando a configuração de um jardim preenchido com uma mistura densa de óleo e perfume. Após breve permanência no ambiente, o que fora inicialmente percebido como aroma agradável se torna, para o visitante, cheiro intoxicante. Dessa maneira, a instalação Vanishing point, 1998, apresenta um percurso inverso ao dos jardins, quanto maior o tempo exposto, maior é o desejo em sair, se afastar. A fragrância é demasiadamente acentuada, provocando algumas reações avessas como a intoxicação, enjoo e vertigem. A artista compreende o olfato como metáfora, um jeito de falar sobre a ideia de intoxicação, do exagero, pois tudo depende da dosagem, que pode ser tanto agradável como desagradável.

Para Soares, o desejo é isso. Ele é perseguido igual como o ponto de fuga: cada vez que o espectador se move em direção a ele; ele se afasta um pouco num constante movimento. O perfume é um elemento irritante. Solúvel em água é uma cópia barata de um perfume famoso, que curiosamente atraem as abelhas aos tanques, assim como Narciso, elas cometem suicídio, não pelo desejo de seu próprio reflexo, mas sim pelo desejo do simulacro aromático das flores do jardim. 


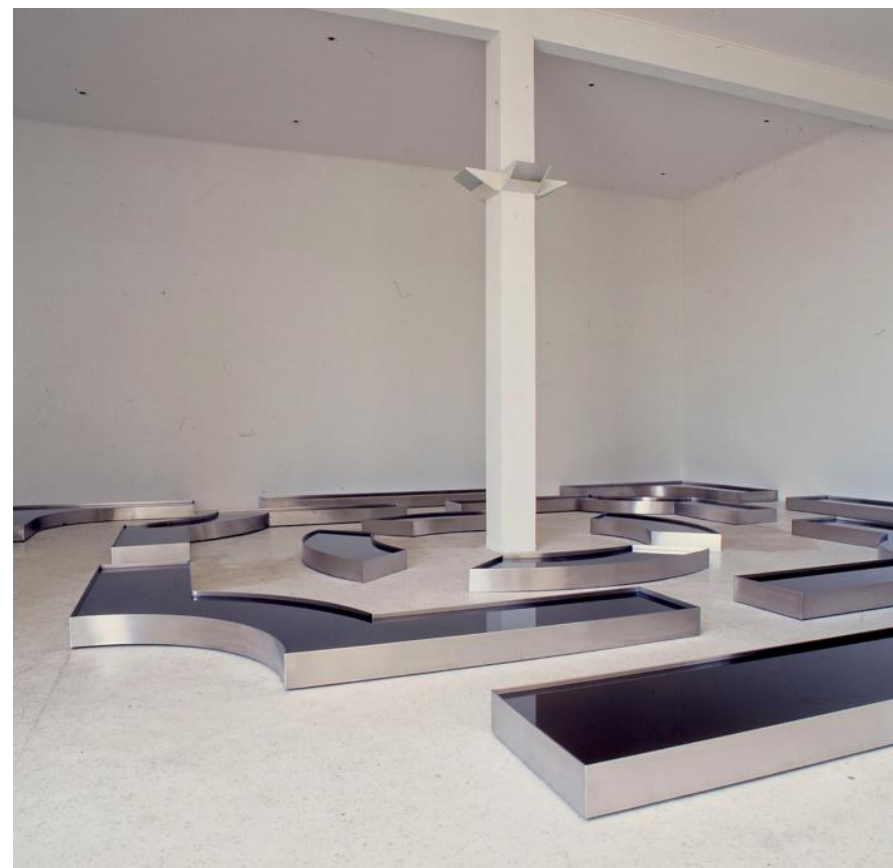

Figura 32. Valeska Soares Vanishing point, 1998, Instalação. Tanques de aço, água e perfume. Fonte: < http://valeskasoares.net/work/vanishing-point/>, acesso em 27 ago. 2019.

(...) Por exemplo, eu vivo nesse universo, eu sou uma pessoa construída, dentro da minha cabeça, de certo jeito. Cada vez que olho no espelho levo um susto, porque existe uma distância entre o que eu acho que sou e aquilo que vejo... Eu não sei como você me vê. Acho que, de uma forma simplista, é isso que me fascina, com a matéria do espelho e me fascina no trabalho é essa distorção ou a impossibilidade de capturarmos uma imagem ou de capturarmos alguma coisa. Além de ter essa dimensão, sei lá. Borgeana, o espelho é um universo dentro de um universo, mas que rebate e volta em você. É um material que parece translucido, mas que é mais sólido do que os sólidos (SOARES, apud HERZOG, p.4, 2006).

O espelho para Soares é um material que tal como os jardins europeus e labirínticos vem perseguindo desde o começo dos tempos, contém uma série de contradições que a fascinam, especialmente no que tange às ideias de reflexão, distorção e representação.

Na instalação Untitle (From vanishing point), 1996, (Figura 33), a ideia de ponto de fuga é central. Nesse sentido, a artista trata não apenas da capacidade de percepção ou da construção do espaço, como ente físico e ilusório. Soares reproduz um conjunto de vasos de plantas, tal como estavam dispostos em seu jardim. Replicando em cera, porcelana e alumínio, cria-se um simulacro, marcando a ausência da vida como força orgânica. Replicam assim a estrutura da memória, uma vez que só é possível lembrar a partir do presente e é da experiência do agora que se preenchem as lacunas do passado, do seu jardim cultivado há anos. 


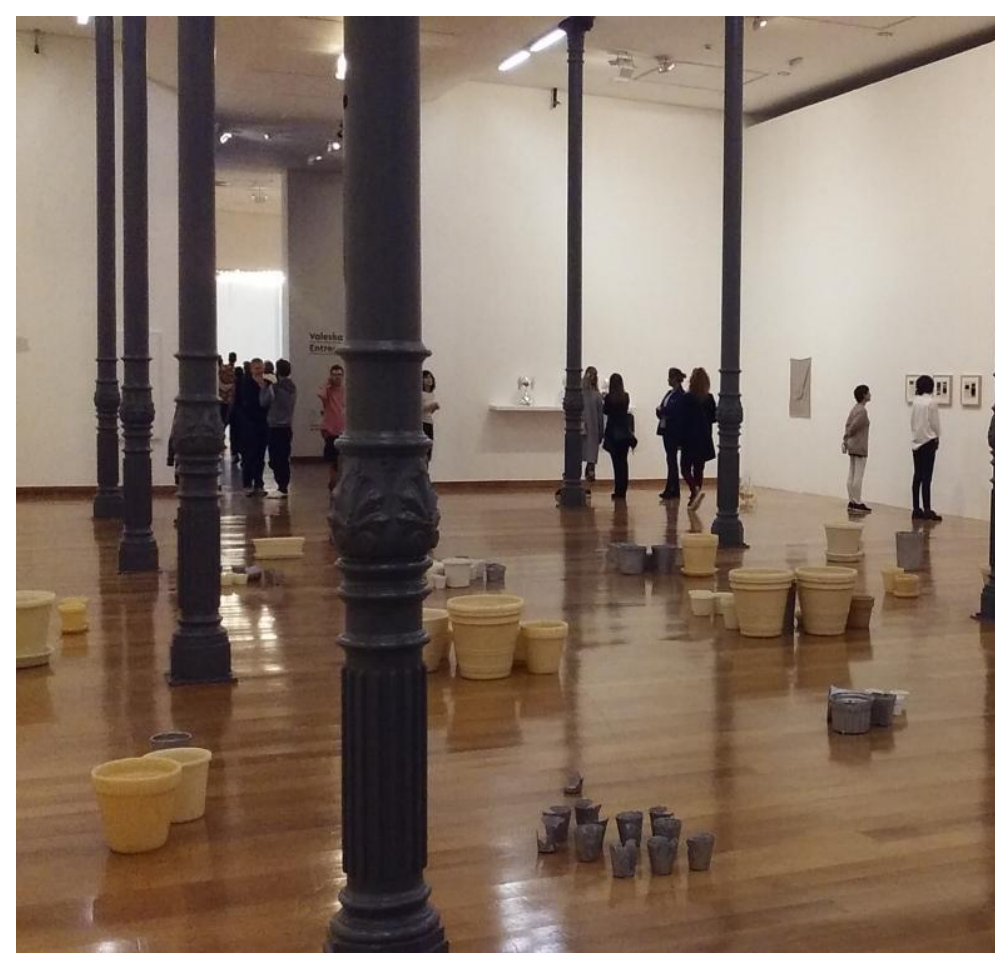

Figura 33. Valeska Soares Untitled (From vanishing point), 1996. Instalação moldes de cera de abelha e alumínio dimensões variáveis. Estação Pinacoteca. Fonte: acervo da autora.

Este trabalho é uma memória ou um index esvaziado do antigo jardim da artista no Brooklyn. Trata-se de 123 pires e vasos de flores moldados em diferentes materiais conforme um sistema de equivalências: cera para os vasos e pires originalmente terracota, alumínio para os de plástico preto e porcelana para os de plástico branco. (MUNIZ, 2005. p.50).

O jardim é um local projetado para meditação entre o mundo físico e o mental, no qual o homem pode novamente vivenciar seus laços com o mundo natural sem renunciar à civilização. Soares constrói seu metajardim, uma heterotopia como o espelho, um lugar que existe, mas não se pode alcançar, que fica no passado, na memória da artista apenas.

Em Detour, 2002, (Figura 34), ela faz referência a fabula de Lewis Carroll, em Alice através do espelho o que Alice encontrou lá: uma porta giratória leva os visitantes a entrarem numa sala iluminada e ampla, onde duas das paredes, situadas em faces opostas do ambiente, são recobertas por espelhos. Nas demais paredes, imagens fotográficas de portais de antigos jardins renascentistas. Na reflexão dos espelhos, não há repetição infinda de imagens idênticas, pois há um sutil desvio de prumo. O que se nota é uma proliferação especular de imagens, seja dos portais, seja do público que ocupa a sala, dando a ilusão de proliferação especular, como de portais que criam um túnel de espelhos, como aquele em que Alice entrou. 


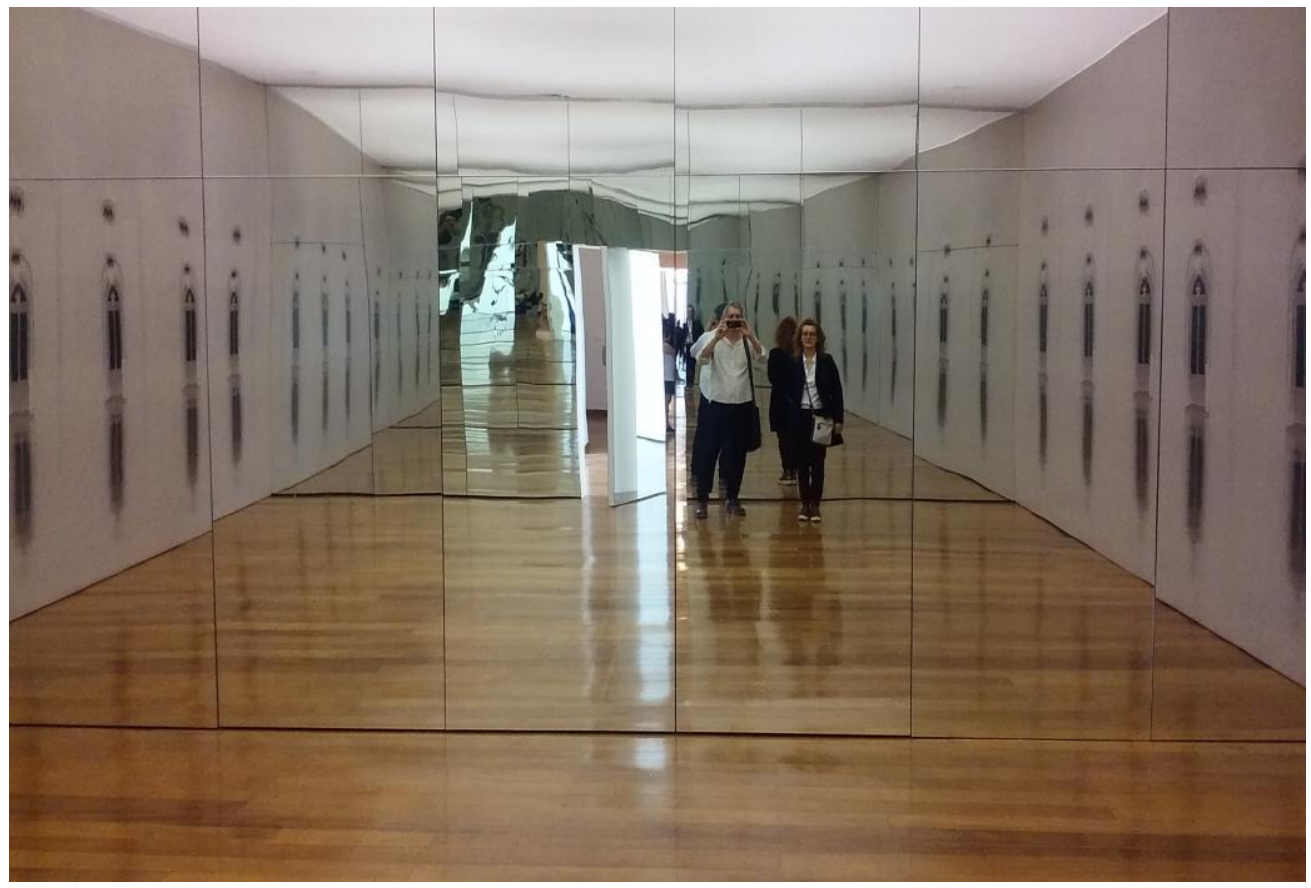

Figura 34. Valeska Soares. Detour, 2002. Instalação, espelho, fotografias digitais e som, 365,8 x 833,3 cm. Estação Pinacoteca. Fonte: acervo da autora.

Segundo o escritor Carroll (2010, p. 17), há uma fronteira precisa entre dois universos para passar de um para outro, é preciso submeter-se a um rito, entrar na toca e cair no poço ou então atravessar o espelho. Nessa direção, entre o tempo, memória, sonho e a loucura, diante de uma superfície reflexiva, ao deslocar-se pela sala, o visitante ouve vozes distintas que contam uma mesma história por todo tempo. "É a história de Zobeide, cidade fantástica criada pelo escritor Ítalo Calvino em Cidades Invisíveis" (ANJOS in SOARES, 2004). Nela as ruas giram em torno de si mesmas como um novelo, quase um novelo, uma sala de espelhos, numa caixa catóptrica.

Nessa imagem espelhada há o fascínio. Eco (1989), em seus estudos sobre o espelho - a partir dos escritos de Lacan sobre a fase do espelho - aborda-o como "fenômeno-limiar" que demarca fronteira entre o imaginário e o simbólico, sugerindo que a percepção e a experiência especular caminhem lado a lado. Nesse fenômeno, ocorre a mudança de vetor do eu especular para o eu social: o espelho é a "encruzilhada estrutural" e se encontra, portanto, na ontogênese do indivíduo. Não é à toa que Alice quer entrar no espelho:

(...) eis que percepção, pensamento, consciência da própria subjetividade, experiência especular e semiose aparecem como momentos de um nó bastante inextrincável, como pontos de uma circunferência cujo ponto de partida parece difícil estabelecer (ECO, 1989, p.12). 
O espelho ${ }^{18}$, como confirma Foucault (1967), funciona como uma heterotopia. Nesse momentum, transforma o lugar, o que o espectador ocupa no momento em que se vê no espelho, num espaço e num só tempo absolutamente real. Ele não se apercebe desse espaço real e tem de atravessar esse ponto virtual que está do lado de lá.
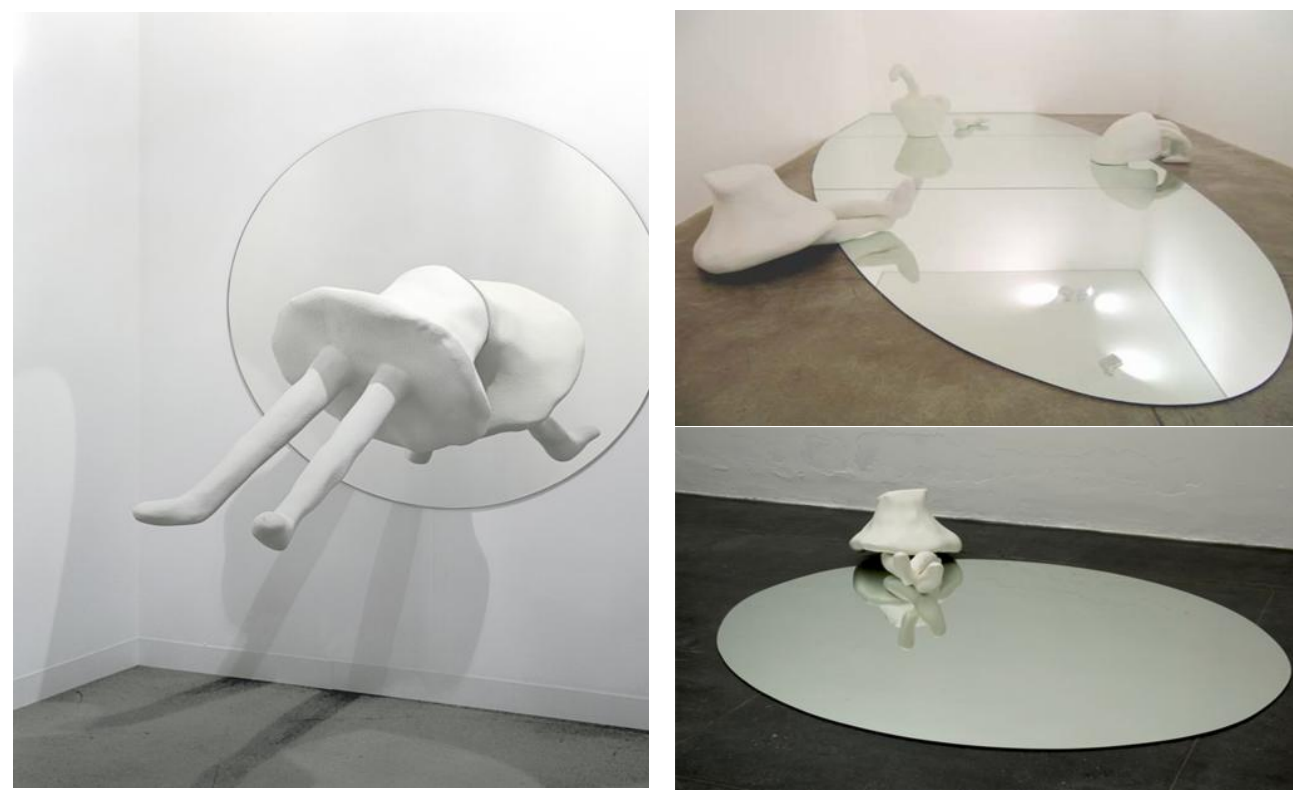

Figura 35. Valeska Soares. Série Narcissus I, II, III, 2005. Variável de Espuma, Resina, Tinta e Espelho. Galeria Fortes Vilaça. Fonte: Site oficial do artista

A instalação Narcissus I, II e III, 2005, (Figura 35) é exposta na galeria Fortes Vilaça, em São Paulo, entre 07 de julho e 06 de agosto de 2005. Nota-se a marcante presença do espelho como o elemento no seu vocabulário formal. A artista tem interesse declarado pela ficção e pela noção de lugares imaginários. Nessa instalação, Soares evoca o mito de Narciso, o jovem que se apaixona por sua própria imagem refletida em um espelho d'água: o amor do homem por sua própria imagem; por esse rosto que se reflete numa água tranquila. Diante dos reflexos da água, Narciso tem a revelação de sua identidade e de sua dualidade, a revelação de seus duplos poderes viris e femininos, a revelação, sobretudo, de sua realidade e de sua idealidade. Bachelard (1989) auxilia na

\footnotetext{
${ }^{18} \mathrm{O}$ espelho é uma heterotopia de ilusão por unir a realidade e não-realidade. Heterotopia (aglutinação de hetero $=$ outro + topia $=$ espaço $)$ é um conceito da geografia humana, elaborado por Michel Foucault que descreve lugares e espaços que funcionam em condições não hegemônicas. Ele usa o termo para descrever espaços que têm múltiplas camadas de significação ou de relações a outros lugares e cuja complexidade não pode ser vista imediatamente. A heterotopia de ilusão usa objetos reais para criar ilusões e fantasias, como por exemplo, espelho, livros e filmes de ficção. Disponível em: <https://pt.wikipedia.org/wiki/Heterotopia_(filosofia)\#Refer\%C3\%AAncias〉, acesso em: 03 set. 2019.
} 
compreensão sobre a natureza de Narciso e sobre os poderes da água, em que naturalmente todo jardim, toda fonte é magica, dotada de poderes divinatórios:

A contemplação de Narciso está quase fatalmente ligada a uma esperança. Meditando sobre sua beleza, Narciso medita sobre seu porvir. O narcisismo determina então uma espécie de catoptromancia natural. Aliás, as combinações de hidromancia com catoptromancia não são raras. Mas, Narciso, na fonte, não está entregue somente à contemplação de si mesmo. Sua própria imagem é o centro de um mundo (BACHELARD, 1989, p.26).

O mito de Narciso que perpassa algumas das obras anteriores de Soares é tratado aqui de forma mais direta, com inteligência e inovação formal. Ela traz reflexões sobre alguns "tipos de Narcisos", um cuja contemplação passiva o paralisa ao se deparar com seu reflexo e também um Narciso que pula na toca do coelho, buscando o encontro de sua percepção, pensamento, consciência da própria subjetividade. É conflituosa a afirmação de identidades, não só de um indivíduo, mas também de um coletivo.

Igualmente, nas três esculturas da instalação de Soares, Narcissus parecem manequins ou bonecas vestidas de saias. Sem cabeça, em diferentes posições, sobre um "lago" de espelho disposto no chão ou na parede da galeria. A artista tem o projeto tridimensional de uma série de desenhos que a artista vem fazendo há alguns anos sobre papel e porcelana. São pequenos esquetes em que a figura humana aparece esboçada apenas. Tanto os desenhos quanto as esculturas nota-se um caráter imediato e um aspecto comovente, entre o humor e a busca de um rosto (identidade, reflexo). Nessa disposição, nota-se a falta de um rosto nas esculturas, existindo apenas fragmentos de corpos, uma possível ausência de identidade que constitui os indivíduos no processo de individuação ${ }^{19}$.

Narcissus, 2005, relaciona-se com a apropriação, reinvenção de um rosto. $\mathrm{Na}$ aproximação dessas ideias de busca da individuação; a busca de uma identidade/essência aparente, Valeska convida à reflexão sobre a matéria e a natureza do espelho. Nesse jogo de "miradas" até que ponto os espelhos são fidedignos? Até que

\footnotetext{
${ }^{19}$ A individuação, conforme descrita por Jung, é um processo através do qual o ser humano evolui de um estado infantil de identificação para um estado de maior diferenciação, o que implica uma ampliação da consciência. Através desse processo, o indivíduo identifica-se menos com as condutas e valores encorajados pelo meio no qual se encontra e mais com as orientações emanadas do si mesmo, a totalidade (entenda-se totalidade como o conjunto das instâncias psíquicas sugeridas por Carl Jung, tais como persona, sombra, self, etc.) de sua personalidade individual. Jung entende que o atingir da consciência dessa totalidade é a meta de desenvolvimento da psique e que eventuais resistências em permitir o desenrolar natural do processo de individuação é uma das causas do sofrimento e da doença psíquica, uma vez que o inconsciente tenta compensar a unilateralidade do indivíduo através do princípio da enantiodromia (é um termo criado pelo filósofo Heráclito para o conceito de que uma grande força em uma direção gera uma força no sentido oposto). Disponível em: <https://pt.wikipedia.org/wiki/Individua\%C3\%A7\%C3\%A3o > , acesso em: 03 set. 2019.
} 
ponto refletem a imagem fiel de um rosto? E sobre as máscaras desses supostos rostos refletidos? Os espelhos seriam capazes de mostrar os rostos tal como de fato o são? Na busca por respostas, nota-se que Jung descreve o processo no qual a máscara, a Persona, cola-se de tal modo ao rosto que, ao se tornar uma máscara "apagada" contra a vontade do indivíduo, pode levá-lo à morte.

Percebe-se em Narcissus, 2005, que a obra surge a partir de pequenos moldes que passam por um scanner $3 D$. Sua forma depois é aplicada sobre blocos de espuma numa dimensão maior. Essa inversão de escalas faz com que a escultura adquira um tamanho quase humano, além de guardar a marca da mão do criador aparente no molde original. É como se esses bonecos estivessem no meio do processo de virar seres humanos, análogo ao processo de individuação, como já descrito por Jung. Essas partes moldadas que compõem o Narcissus são apenas fragmentos de três indivíduos em busca de uma suposta "totalidade" do ser. Embora, a transformação nunca se consuma de fato. Semelhante aos contos de fadas, esse processo trata de histórias de bonecos que desejam ser gente, como é o caso de Pinóquio ${ }^{20}$. O boneco de madeira encantada busca sua redenção, através das boas ações que, no fim da sua trajetória, por conta de seus bons feitos conquista o direito de ser um menino de verdade.

Ainda sobre a instalação Narcissus, vale apontar que essa obra dialoga com outra instalação de Valeska Soares, a Puro teatro, 2003 (Figura 36), apresentada no Museo Rufino Tamayo, na cidade do México. A obra faz parte de um projeto chamado Pavilhão do desejo. Nessa ocasião, Soares cria um imenso lago de espelhos em acrílico, onde os visitantes são convidados a tirar os sapatos e "andar sobre a água", assim como o milagre de Jesus. Uma oportunidade única, um convite a "participar de um verdadeiro banquete narcísico", nas palavras de Medina (2005), crítico e curador mexicano.

No centro do "lago de espelhos", Soares escolhe um lugar de melancolia e contemplação retirado de um pesadelo ou de um conto de fadas. Pois se trata de um pavilhão coberto, ou melhor, uma armação arquitetônica feita de metal e vidro transparente com um divã feito de bolo confeitado com merengue do lado de dentro, como mostra a (Figura 36). O bolo fora produzido por uma confeitaria tradicional especializada em bolos barrocos, chamada Confeitaria Ideal (um nome perfeito) para representar as cerimônias das famílias mexicanas. A obra em formato de divã é a maior

\footnotetext{
${ }^{20}$ Personagem principal da obra As aventuras de Pinóquio (em italiano Le avventure di Pinocchio. Storia di un burattino), romance escrito por Carlo Collodi, em Florença, em 1881 e publicado dois anos depois com ilustrações de Enrico Mazzanti.
} 
encomenda já produzida pela centenária confeitaria até hoje. O divã simula os botões e as pregas de maneira realística, em sua branca superfície, tal como é o divã representado em mármore na escultura Hemafrodita dormindo e Lorenzo Bernini. Além da ironia sobre a sedução dos psicanalistas, a instalação exposta ao tempo, por meses, apodrece e se despedaça, a ponto de manchar o lago espelhado. Como se a matéria orgânica em composição poluísse o lago, desmascarando as ilusões e doces sonhos tão presentes na infância, mas com o passar dos anos se transforma em memórias quase apagadas na vida adulta.

Os espelhos revelam um cosmo em miniatura, transpondo sempre à beira de uma desaparição, pois ao se aproximar demais, perde-se a completude da imagem. Isso também acontece com Narciso, quando se aproxima demais do reflexo da água, a imagem refletida se apaga pelas ondas. As intervenções teatrais de Soares oferecem uma experiência não ilusória do maravilhoso que recusa a passar pelo fantástico. Afinal, o fantástico se define pelo modo com que o público está consciente de que tudo que vê é pura ilusão, o espectador tem consciência de que tudo que vê é uma não-realidade. Com esse conceito, Soares leva o espectador a ter a sensação de sonhar acordado. Nessa instalação, o objetivo não é consumar as fantasias. Pelo contrário, Soares induz ao espectador a refletir, contemplar sobre os desejos e sonhos. Por isso, a alusão à Alice, a personagem de Lewis Carroll, que sempre tem razão em perguntar: "quem sonhou isso?" (CARROLL, 2010, p.313).

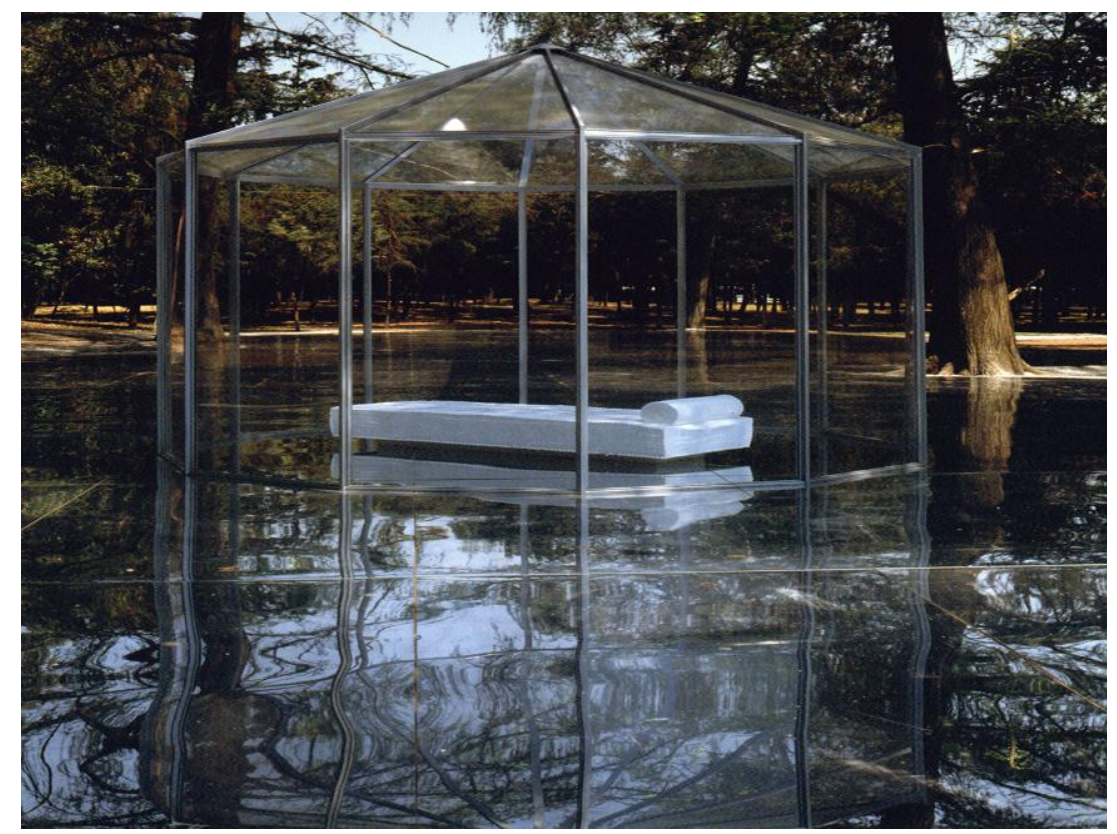

Figura 36. Valeska Soares. Puro teatro, 2003. Fonte: Site oficial do artista. 
Diante dessa travessia dos reflexos entre realidade e sonhos, chega-se ao fim deste tópico sobre as aproximações estéticas entre as obras de Soares. Tem-se como objetivo a compreensão de sua trajetória estética. A artista contribui para esse entendimento porque, em entrevistas, ela atesta que suas obras podem ser articuladas umas às outras ou separadas, contemplando, desse modo, uma sucessão densa de significados até a obra Folly - objeto do presente estudo. No total, selecionam-se seis obras, espalhadas pelos parques, galerias e museus do continente americano, capazes de explicitar as narrativas que levam à instalação do jardim botânico de Inhotim.

Assim sendo, Picturing paradise, 2000 (Figura 37) e Self portrait in denial (Figura 38) são as obras selecionadas para encerrar a abordagem sobre a trajetória de Soareas com o intuito de atingir a complexidade das interpretações de Folly. O projeto InSite, realizado nas cidades fronteiras de Tijuana (México) e San Diego (EUA), resulta em Picturing Paradise, 2000. Nessa instalação, as fronteiras são locais de espreita, de contato e de confronto com o outro; são espaços de formação de ideias de si e de demarcação de diferenças. São, potencialmente, locais de passagem, de incessante permuta de bens e desejos. As fronteiras são lugares de exclusão e afastamento. Nessa instalação, a artista comenta:

(...) o espelho constrói um espaço, uma fenda dentro de mim. Em sua
superfície a percepção de mim mesmo a frente do meu eu externo, a imagem
com a que se encontra no mundo. O espelho articula a discrepância existente
entre os meus dois eus (...). Os eus externos e interno que o espelho
identifica, opõe-se, se definem entre si e buscam articular em um eu
unificado. O resquício criado pelo espelho é um espaço de negociação que
contem a possibilidade o desejo de uma imagem reconciliada de si mesmo.
(SOARES, 2005, p.84).

A artista escolhe uma área de fronteira onde a barreira é feita de arame vazado ao invés de folha de metal maciça, isso permite que as pessoas de ambos os lados da fronteira se vejam, assim como é o país contiguo. O território fronteiriço, articulado por essa cerca, é um espaço complexo, representando os sonhos e medos, a pobreza e prosperidade. As cidades fronteiriças Tijuana e San Diego estão tensamente entrelaçadas, suas economias e suas populações se mesclam e fazem referência umas as outras continuamente. Cada cidade é definida pela outra. As ruas caóticas e sujas de Tijuana tem seu contraste com a ordem militar e a limpeza das amplas ruas e avenidas de San Diego. O pó seco da paisagem desértica de Tijuana contrasta com a vegetação exuberante de uma San Diego bem irrigada e rica. 
A população de Tijuana vai para os EUA em busca de oportunidades econômicas e fortuna, enquanto a gente de San Diego vai ao México em busca de prazeres proibidos como a bebida em excesso, as drogas baratas e os encontros sexuais ilícitos. Essa percepção do outro lado da fronteira constrói uma autodefinição dos habitantes de cada cidade. A fronteira se converte num espaço de negociação habitual, conforme as normas culturais e as atividades do "outro" de cada cidade, onde podem ser adotadas ou rechaçadas. Às vezes essas interações podem parecer de pouca relevância, como a adoção de termos, modos e produtos estadunidenses por parte dos mexicanos, ou a busca de comida mexicana, artesanatos e outros acessórios decorativos para a casa por parte dos estadunidenses. De modo que, em outras ocasiões esses intercâmbios são agressivos, como por exemplo, quando os mexicanos lutam contra as intervenções econômicas e políticas por parte dos EUA. Ou quando os EUA suprimem as influências culturais mexicanas pretendendo reforçar a impermeabilidade da fronteira.

No sentido dos espelhos colocados no muro, Soares inscreve um fragmento da obra Cidades invisíveis, de Ítalo Calvino. O fragmento apresenta a descrição da cidade fictícia Valdrada e sua projeção virada de ponta cabeça (CALVINO, 1990, p.53). O texto relata como as duas cidades se vigiam constantemente, onde a cada ação violenta ou amorosa executada em um lugar, simultaneamente, se inverte, se repete, repercutindo dentro do espaço de sua imagem como um espelho. O reflexo perturba os moradores de ambos os lados e a dimensão replicada devolve agudamente a consciência de si próprios.

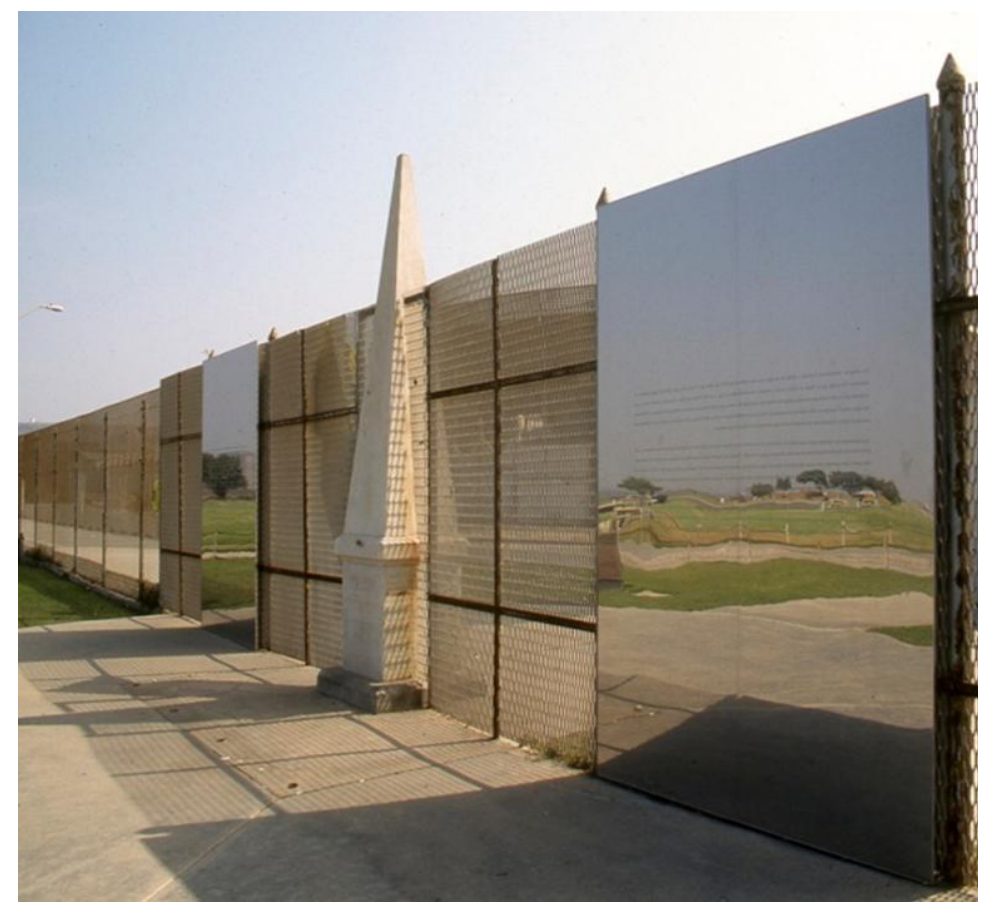

Figura 37. Valeska Soares. Picturing Paradise, 2000. Fonte:

Site oficial do artista. 
O texto de Calvino surge no lado mexicano em escrita espelhada com o texto ao revés para os estadunidenses. O mesmo acontece com o texto escrito do lado estadunidense da fronteira em escrita espelhada para os mexicanos. Todavia, onde está escrito em espanhol só pode ser lido do lado mexicano corretamente e o mesmo ocorre do lado norte-americano com a língua inglesa. Os textos invertidos criam a ilusão de transparência, como se o observador estivesse olhando através do espelho a superfície do país oposto. Nessa concepção Foucault (1986) descreve em De outros Espaços, uma sociedade contemporânea angustiadamente preocupada com o espaço. Nesse ensaio, são apresentados alguns dos fenômenos socioculturais que merecem atenção para o entendimento sobre os espaços e seus reflexos na sociedade.

Como já mencionado, os espelhos, para Foucault (1986), representam a união entre utopia e heterotopia. Ele discorre a respeito da heterogeneidade dos espaços sociais. Inicialmente, relata ser possível descrever diferentes "sítios" de relaxamento temporário, tais como, cafés, cinemas, praias, etc., bem como, sítios fechados ou semifechados de descanso, tais como, casa, quarto, cama, etc. Todavia, a Foucault (1986, p.3) interessa discutir aqueles sítios "que se relacionam com outros sítios", de modo que neutralizam a segunda ou inverte a rede de relações por si designadas, espalhadas e refletidas. Em outras palavras, trata-se de espaços que se encadeiam uns nos outros, mas que também, ao mesmo tempo, se contradizem.

\begin{abstract}
A complexidade da instalação Picturing paradise, 2000 pode comparar-se ao emprego do espelho por parte de Foucault como exemplo de utopia e heterotopia. O espelho de Foucault especifica um lugar - com todo seu sentido social e político implícito - dentro do espaço subjetivo do indivíduo. Sou eu quem enfrenta o espelho e negocio as relações espaciais que este crê, assim como suas implicações. Os espelhos identificam um limite definido politicamente como um sítio de autodefinição (SOARES, 2005, p.86).
\end{abstract}

O indivíduo frente à obra vê sua imagem refletida de volta ao país de onde está, enquanto que ao mesmo tempo pode ver através da cerca de arame o outro território à diante. A inserção dos textos invertidos e legíveis reforça a consciência dos dois pontos de observação distintos, que definem o espaço de cada um. Nota-se que o termo utopia implica em desejo por outra vida. Picturing paradise, 2000, demonstra que para cada indivíduo que habita um lado da fronteira existe outro eu diferente no outro lado, vivendo dentro de um conjunto de presumidas liberdades. Essas supostas liberdades definem como oportunidades econômicas ou como a liberação de costumes e normas culturais restritivas (SOARES, 2005). 
Para cada população essas utopias imaginadas são paralelas em estrutura, entretanto, distintas em conteúdo. O eu utópico visível, define a posição do indivíduo contrastante com a concepção heterotópica do autoconhecimento, contendo informações da localização específica do indivíduo. Soares em seus espelhos propõe a visibilidade nas negociações fronteiriças fisiológicas, psicológicas do indivíduo. "Como os espelhos revelam o meu interno e externo e como se vinculam com minha posição geográfica e cultural. Estes eus de fora e de dentro definem o lugar de onde estamos" (SOARES, 2005, p. 86). A fronteira estabelece uma série de dicotomias, mas a pessoa que encontra essas polaridades dentro do espelho-fronteira busca inevitavelmente unificá-las. Ao mesmo tempo, os espelhos-fronteiras adentram o Oceano Pacífico, demonstrando que os resquícios físicos dessa barreira se desfazem de maneira comovente, diante do oceano unificado no horizonte. Nesse horizonte, os pensamentos e desejos de um território único em toda humanidade se estabelecem mesmo que em segredo dentro de cada indivíduo que sofre a dor de não pertencer.

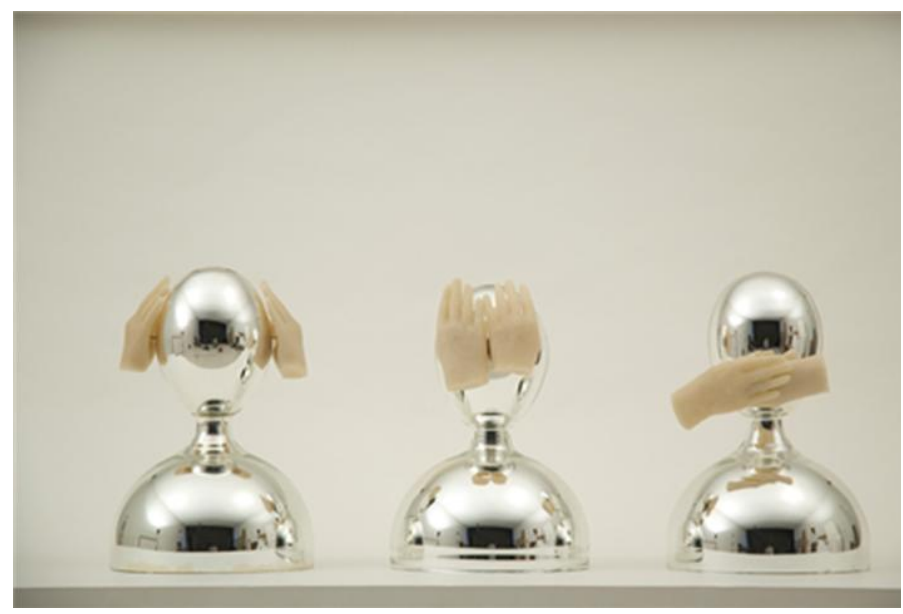

Figura 38. Valeska Soares. Self portrait in Denial, 20042018.Vidro espelhado e cera 15 x 44 x $30 \mathrm{~cm}$. Fonte: site oficial da artista.

Na obra Self portrait in denial (Autorretrato da negação), 2004-2018 (Figura 38), assim como em Narcissus I, II, III, 2005, os artefatos parecem não reconhecer a fronteira entre o próprio eu e os outros. A instalação transmite a sensação de repressão, especialmente porque as mãos negam a própria existência, as mãos de cera que censuram os sentidos da audição, visão e a fala: uma espécie de não-existência 
semelhante aos bonecos da série Narcissus I, II, II, 2005 (Figura 35), só o corpo existe; um corpo sem rosto, sem identidade ou individualidade.

A partir do mito de Medusa enfrenta-se a imobilidade (vira pedra quem a olha) para afirmar-se como imagem-tempo, ou seja, imagem sequencial. O autorretrato pressupõe a ideia de uma micronarrativa embutida nela mesma. Barthes (1984), em Câmara Clara, refere-se à identidade como algo impreciso e imaginário, pois se assemelha à cópia da cópia, questionando o sujeito no retrato, no surgimento do eu com o outro. A pose é um artifício técnico que abranda o efeito da realidade na fotografia. Ela permite a construção de máscaras para escamotear o caráter físico (BARTHES, 1984, p. 27). A pose assume o caráter de simulacro; o sujeito torna-se o modelo no puro jogo teatral das aparências. A duplicação dos códigos manifesta o dispositivo Narciso. A preocupação do duplo na foto é interpretada de duas maneiras: o duplo na foto e o duplo no espelho. O autorretrato consiste em aprofundar a reflexão sobre si. Segundo o ponto de vista tradicional, realizar um autorretrato é olhar-se, tomar consciência de si como um todo unificado ${ }^{21}$. A fotografia é uma imagem extraída de um ponto no tempo e espaço. É como se obturador fosse a guilhotina da duração.

O fotógrafo corta, o pintor compõe. Barthes (1984) considera a pose com um simulacro, no qual o sujeito é o modelo no jogo teatral das aparências. Self portrait in denial, 2004-2018, aparenta uma encenação do eu com outro. Nesse sentido, Barthes (1984) e Baudrillard (1997) são autores que compreendem a fotografia, em particular o autorretrato, como instrumento privilegiado da arte da desaparição, signo do sujeito ausente. A obra de Soares é feita de material espelhado. Apresenta em forma de busto ou o manequim espelhado de lojas (Figura 38) - como ignoto, algo que precisa ser reconhecido e identificado pelo espectador. O estranhamento dos bustos se dá um interatividade com o público. Em se aproximando das esculturas o espectador se reflete, se vê dentro da obra, como anamorfose ${ }^{22}$ do espelho. A partir desse primeiro contato com a obra, a percepção do público traz uma dimensão mágica: de longe não há identidade; de perto o espectador entra na obra, dando forma e identidade. Traz a fiel ilusão com distorções e reflexos, acumulando identidades fantasmagóricas. Essas percepções produzem o despojamento do modelo, um artifício de caráter teatral que capta a ideia de máscara e alteridade.

\footnotetext{
21 As definições de autorretrato e selfie estão presentes nas partes 1.2 e 1.3 desta pesquisa.

${ }^{22} \mathrm{Na}$ óptica, a anamorfose se dá quando ocorre ampliação das imagens, por meio de espelhos especiais, prismas lentes e outros sistemas óticos. Disponível em: < https://pt.wikipedia.org/wiki/Anamorfose>. Acesso em 30 set. 2019.
} 


\subsection{Instalação: Folly}

Chega-se no momento final, a análise da instalação Folly (Loucura), 2005-2009, de Valeska Soares (Figura 39). Empregando o espelho, os reflexos e a natureza, Soares cria, num mundo de oposições constantes e propostas abertas, uma estrutura arquitetônica às margens de um grande lago que reflete a paisagem ao redor, com águas azuis cristalinas $^{23}$. O processo de criação da obra é explicitado pela artista:

O processo do meu trabalho foi envolvido com sistemas que funcionam fora da razão. Percebi a semântica paradoxal disso, mas o que eu quero dizer é que sempre me interessei em como a loucura e a fé operam, uma porta que tem seus próprios sistemas de raciocínio (SOARES, 2005, p.22).

Folly (Figura 40) é um pavilhão que se diferencia dos demais, pois o ambiente ao entorno é resultado de um projeto paisagístico entre a artista e a equipe botânica do Instituto Inhotim. A instalação possui forma octogonal com lados cobertos com espelhos, remetendo a um coreto de praça, como é comum nas cidades do interior do Brasil. Na parte externa, o coreto se posiciona acima do chão sobre uma espécie de deck de madeira com pilares também de madeira.

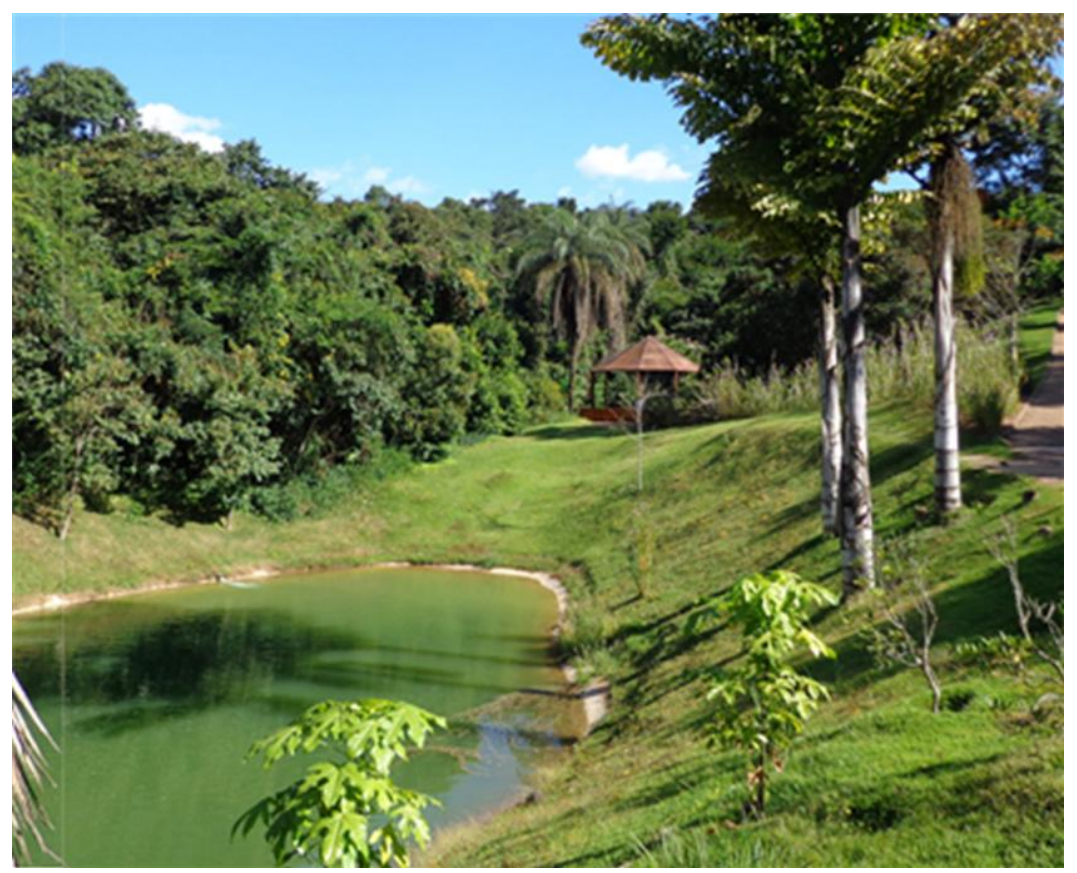

Figura 39. Valeska Soares, Folly, 2005-2009, lago projetado com espelho d'água espelho d' água; pavilhão de madeira e espelho. Fonte: acervo da autora.

${ }^{23}$ Águas do lago são tingidas com um verde ou azul para compor o visual paisagístico espelho d'água, arquitetura, natureza e espelho. 
Logo na chegada, o cenário envolve o espectador. O caminho até a instalação é recoberto por pedras ornamentais e mostram-se os reflexos da natureza nas paredes da obra e no lago próximo. Assim, o público é convidado a se interiorizar, observar em virtude da sonoridade ao pisar pelo caminho das pedras. Trata-se de um tipo de paisagismo diferente do aplicado a maior parte de Inhotim, pois tem características de um jardim residencial. Além do lago, as árvores frutíferas e flores coloridas, no espaço que precede a obra, o visitante pode se sentar em grandes bancos de madeira sob as sombras das árvores para contemplar a paisagem em contato com o ambiente. A paisagem ao redor reflete nos espelhos, dando a ilusão que as paredes são vazadas. Contudo, essa falsa impressão se perde, à medida que há a aproximação com o coreto, isto porque se vê na realidade o conjunto: a paisagem do entorno e a própria imagem do espectador refletida nos espelhos.

Nessa obra, Soares propõe o elemento espelho e seus reflexos como evocação para expansão do espaço e da consciência de si. Proporciona ao espectador a sensação de estar num lugar com a natureza alterada, tal como num jardim/pomar, contudo, também remete à atmosfera do conto de fadas ou a do sonho. Nessa direção Bachelard (1989, p. 51 e 52) esclarece essa sensação de lugar onírico: “onde está o real: no céu ou no fundo das águas?”. O infinito do sonho é tão profundo no firmamento quanto sob as ondas. Através dessa construção do reflexo absoluto, nessa deliciosa viagem de opticidade dos reflexos, a paisagem refletida está submetida a uma idealização sistemática; a miragem corrige o real, os espelhos, a luz e o mundo das águas nos cria uma solenidade platônica (BACHELARD, 1989, p. 52).

Simultaneamente, ao se miras nos espelhos pelo octógono, o espectador e remetido ao espelho tão puro que, pouco a pouco, ele se sente o autor do que contempla, o mundo é "a minha visão", mundo é "meu ponto de vista”. É importante destacar que, apesar de o lago (Figura 39) e o jardim que compõem o espaço contemplativo serem refletidos e terem sido caracterizados para receber a obra Folly, eles não constituem efetivamente parte da obra.

Ao observar na parte de trás do pavilhão, existe uma porta, uma passagem que dá acesso à sala interna (Figura 41). Na sala escura, o vídeo refletido nas dez paredes de espelhos. Ele apresenta alguns dançarinos solitários na pista do salão, onde, através 
da sobreposição de imagens se cruzam, se afastam ao som da trilha sonora The look of love (1967), de Burt Bacharach, em modo looping. A trilha sonora é uma versão remixada pelo coletivo mineiro $O$ GRIVO (SOARES, 2005, p. 110) essa música faz muito sucesso como trilha sonora do filme de espionagem Cassino Royale (1967). Ao som da música, o vídeo projeta um casal, criando a ilusão da dança juntos, mas os dançarinos se afastam. Percebe-se a presença de três dançarinos que se alternam no vídeo, sobrepondo suas danças. Como o vídeo é filmado em tempos diferentes, aparece pessoas dançando, essa aparição e desaparição promove a impressão de que os dançarinos, ora se afastam, ora se encontram, dando a impressão da incapacidade de se conectarem entre si.

Nessa ambientação de som, sedução e mistério, o espectador emerge numa atmosfera envolvente de glamour, entretanto, hoje representa certa decadência e/ou certa ironia de um passado que quase esquecido. É importante salientar que a obra Folly integra um conjunto de obras exposto em Nova York, no Museu do Bronx, em 2005. Em 2002, a artista faz sua primeira instalação do vídeo no antigo cassino Pampulha, desenhado por Oscar Niemeyer, em Belo Horizonte. O vídeo mostra bailarinos deslizando na pista de dança dessa obra-prima arquitetônica dos anos de 1960.

Tudo se mimetiza pelos espelhos ao redor do pavilhão. As superfícies refletem o jardim, as pedras e as pessoas provocando certa vertigem. Merleau-Ponty (2006, p. 55) afirma que "sempre temos conosco um princípio constante de distração e de vertigem que é nosso corpo. Mas nosso corpo não tem o poder de fazer-nos ver aquilo que não existe". O corpo, o que percebe do ambiente, pode apenas fazer crer que o espectador o vê; que o observador se torna criador da obra, produzindo selfies, personagens únicas criadas com seus cliques através da fotografia. A experiência produz certa ambiguidade, entre o espaço nostálgico, a tecnologia e a arquitetura. Do lado de fora, os espelhos atraem os olhares, as percepções entre o coletivo e o individual, entre a parceria e a solidão. O público é convidado a interagir, participar como parceiro/sujeito/cocriador da obra. Ele é levado a percorrê-la com os olhos e também com o corpo.

Nesse ponto, em Fenomenologia da percepção, Merleau-Ponty (2006, p. 14) afirma que "o mundo não é aquilo que eu penso, mas aquilo que eu vivo; eu estou aberto ao mundo, comunico-me indubitavelmente com ele, mas não o possuo, ele é inesgotável". Mais além, ele complementa dizendo que "nós não pensamos o objeto e não nos pensamos pensando-o, nós somos para o objeto e confundimo-nos com esse corpo que sabe mais do que nós sobre o mundo, sobre os motivos e os meios que se tem 
de fazer uma síntese” (MERLEAU- PONTY, 2006, p 320). Em razão disso, pode-se pensar que o "eu sou e estou refletido na obra". O reflexo do indivíduo é parte dele e do mundo do espelho. Através desse mundo em que o indivíduo transita gera uma conexão entre o ser e as relações em seu entorno.

As questões que Soares investiga através do espelho surgem a partir da percepção e reação do visitante, individualmente e coletivamente. Através do uso do espelho a artista cria a obra vivenciada, ou seja, induz a participação do observador provocando múltiplas interpretações. A fronteira que define o real e o imaginário se evidencia assim que o público adentra a sala escura. Dentro do octógono (Figura 41), imediatamente há um choque visual causado pelo blackout do lado interno. Percebe-se o choque auditivo, isto porque fora da instalação o público permanece num espaço envolto em luz, natureza e conversas; na parte interna o som da trilha sonora tranquila e envolvente. No interior do coreto, o corpo precisa se adaptar a falta de luz. Nesse novo universo no qual o espectador adentra, os sons ganham novo sentido e representação, envolvendo uma narrativa em que o mundo real se distancia; é o entrar na sala dos espelhos mágicos. Nessa junção entre arte, tecnologia e narrativas, a projeção em vídeo invade o visual pelo jogo especular das paredes internas, gerando múltiplas imagens desestabilizando o conceito de tempo e espaço pelas anamorfoses produzidas pelo espectador frente ao espelho. Através da dança, o corpo reinventa-se, brinca ao som da música, imagina outra realidade e vive uma nova experiência.

Assim, Folly é uma instalação criada de forma aberta, como algo a ser concluído, incompleto, descentralizado e pluralizado de sentidos e sensações. Nesse percurso enlaçam o outro, convocando o sujeito a fantasiar, a se apropriar, a reconstituir a seu modo a obra. O público/sujeito é chamado a refazer a história na beleza e na dor no encontro com a artista mediada pela sua criação. O espelho é um rito de passagem, êxodo para dentro da obra, o caminho, o percurso, o convite para mergulhar nas memórias do espectador/sujeito. Na medida, em que o espectador se transporta para o lado de dentro no mundo dos espelhos, ele narcísico é levado a encenar: recebe a incumbência de ser o dançarino que baila, que seduz, que recua e avança no objeto desejado. A fim de se ver, ser visto, seduzir, ser seduzido - que pode ocorrer a partir da própria imagem, uma simples silhueta ou outro corpo que está ao lado pronto a ser tomado. O caráter ativo do espectador se dá como sujeito da experiência que se propõe. É uma espécie de satisfação do próprio desejo. Integrar-se ao espaço, remetendo ao 
espaço, a si mesmo e a outros "eus" de maneira indefinida. O outro pode ser o dançarino que, na dança, não dança, não consolida o amor de verdade.

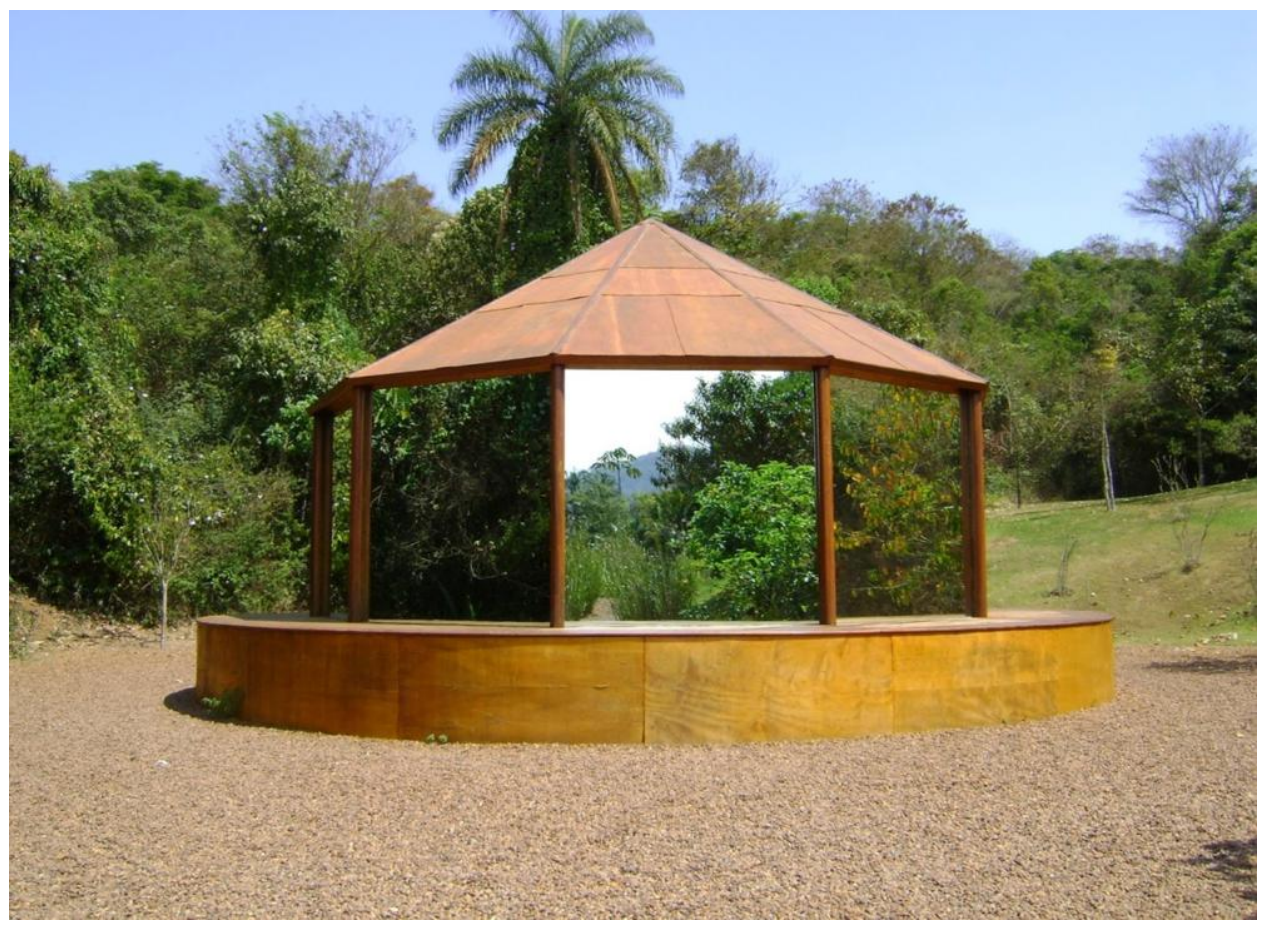

Figura 40 Valeska Soares, Folly, 2005-2009, vídeo transferido para DVD, trilha sonora The look of love, 5 '; pavilhão de madeira e espelho. Disponível em: http://www.inhotim.org.br/inhotim/arte-contemporanea/obras/folly/, acesso em $03 \mathrm{dez}$. 2017.

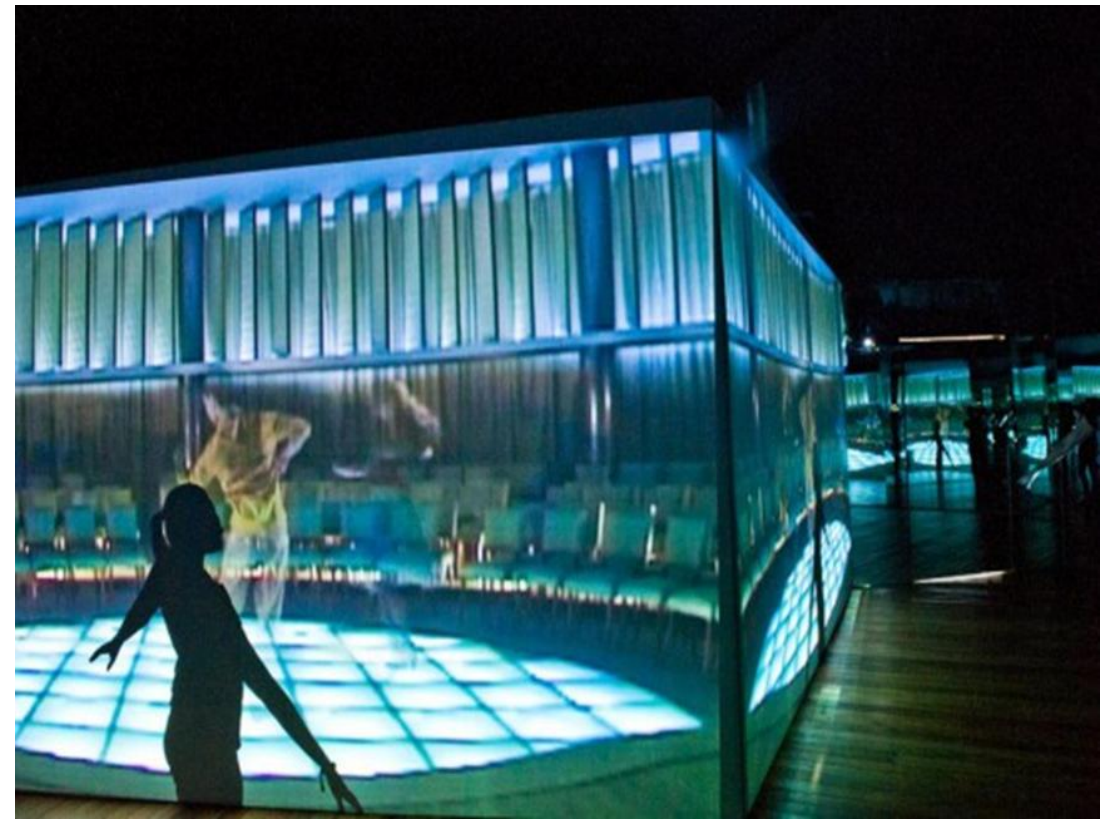

Figura 41. Valeska Soares, Folly, 2005-2009 vídeo transferido para DVD, trilha sonora The look of love, 5'; pavilhão de madeira e espelho (parte interna). Fonte: http://www.inhotim.org.br/inhotim/arte-contemporanea/obras/folly/ , acesso em : 03 dez. 2017. 
A tradução da música toca na questão da "aparência do amor", de que o ser desejado, possui a aparência do amor. A música transporta para esse lugar de sedução e troca de olhares, a aparência do amor, o reflexo do amor nos olhos, assim como em Narciso que se apaixona pela própria aparência refletida no lago, mas não consegue tocar, consolidar esse amor. A maneira como a artista se utiliza da obra, recupera as explorações espaciais de Hélio Oiticica (1937-1980) em seus Parangolés ${ }^{24}$, nos anos de 1960. O artista carioca radicaliza a prática da pintura e expande os suportes, criando uma obra para vestir e ativada por um corpo em movimento. $\mathrm{O}$ ato de vestir-se implica por si só uma transmutação corpórea e expressiva, característica primordial da dança. As obras de Oiticica e a de Soares estão ligadas por fundamentos fenomenológicos. A obra de Oiticica enfatiza a presença do corpo, de maneira que Soares se define pela ausência, sugerindo um corpo fantasmagórico, etéreo (SOARES, 2005, p 110).

Na obra de Soares, os corpos são projetados numa impermanência etérea sobre o espelho, atuando como um cenário. O corpo que dança é um corpo de incertezas que explode o suporte. A atenção flutuante e a dissolução do corpo, “(...) concepção de uma arte apoiada não em convicções, mas em incertezas, explosão do suporte, valorizando o cerne da matéria e ambiguidade" (AJZENBERG, 2003, p. 11). Oiticica utiliza o corpo para ativar seu Parangolé com o intuito de transgredir e contaminar o espaço santificado, numa vivência total do espectador, que agora se chama "participador" (INSTITUTO MOREIRA SALLES, 2017). Em Oiticica, existe um "ciclo de participação", no qual observador e observado ("espectador" e "usuário") (INSTITUTO MOREIRA SALLES, 2017) são postos a expandir os campos do espaço e do tempo. Soares, com a mescla do audiovisual e corpos espectrais e físicos, cria uma evocação ao espaço, revelando uma ocupação do espectador/sujeito/narcísico.

As experiências sensoriais combinadas com o sonho surrealista da loucura de Soares emergem numa surpresa ao entrar na parte interna. A ordem natural é invertida, os espelhos que refletem a paisagem exterior agora dissolvem o recinto interior; a luz do dia na natureza é substituída por um brilho enevoado noturno, emitido por projeções de vídeo infinitamente nas paredes espelhadas de uma sala vazia. E, assim, a imersão se dá através de imagens efêmeras de dançarinos que se movem em todas as direções. Esse

\footnotetext{
${ }^{24}$ Hélio Oiticica, Anotações sobre o Parangolé, exposto em Opinião 65, no MAM RJ, de 12 ago. a 12 set. 1965. Disponível em: https://www.correioims.com.br/carta/os-parangoles-de-helio-oiticica/. Acesso em 03 dez. 2017.
} 
embaçamento visual pela presença e ausência do corpo, da luz, do movimento dos dançarinos que afastam e aproximam, flutuando no salão. Soares explora a dança do desejo e da repulsa, reflexão interna e externa, espetáculo público e privado. Nesse dualismo visual e psíquico, entre fantasia e realidade, entre amor e dança, ela evoca as rupturas da sociedade narcisista, ativando a consciência de suas múltiplas identidades.

Diante de superposições de várias imagens e desencontros, o vídeo projeta a magia da incapacidade dos bailarinos se conectarem. Neste desencontro, o espelho cria um sentido simbólico do acumulador, do aditivo, dos excessos, assim como na sociedade narcisista. A dança de um espelha o palco de dois que não se materializa, como o amor platônico. A força do amor é um "palco de dois". Ele interrompe a perspectiva do um e faz surgir o mundo a partir do ponto de vista do outro ou do diverso.

Dentro da obra Folly, é permitida a analogia da sociedade contemporânea, na qual os dançarinos evocam Eros, o deus do amor. Contudo, diante das infinitas possibilidades, o outro desaparece, a face do amor caminha cada vez mais de mãos dadas com a narcisificação do si mesmo. O outro desaparece nesse oceano de infinitas possibilidades das faces do amor no reflexo especular. No lugar do amor, no lugar do outro, surge o sujeito de hoje voltado narcisicamente ao desempenho, à busca do próprio sucesso, da própria felicidade e da eterna juventude sedutora. Essa lógica do reconhecimento enreda o sujeito de modo ainda mais profundo em seu ego. O sujeito do desempenho mergulha e se afoga em si mesmo, destruindo a possibilidade do amor no mundo contemporâneo (HAN, 2017, p.8-11). Essa pode ser uma das maneiras de interpretar a experiência audiovisual e torná-la uma espécie de satisfação alucinatória do desejo. O espelho das identificações reenvia a si um sujeito esvaziado da sua consciência. Essa experiência estética descreve por extensão todo um estado da sociedade em que predomina os selfies, as imagens da internet em que denigre a memória histórica por um culto frenético ao tempo presente, nas instantaneidades das imagens, dos simulacros, do consumo creditadas amplamente ao narcisismo do sujeito/espectador. 


\section{CONSIDERAÇÕES FINAIS}

Os múltiplos espelhos da história da arte refletem um repertório vasto e necessário para a compreensão de sua natureza e de seu uso pelos artistas. O espelho está presente na vida das pessoas, seja para realização de tarefas cotidianas, seja na inovação nos campos da ciência e tecnologia. Dentro dos reflexos de Inhotim, a presente pesquisa busca trazer à tona a importância do espelho e dos reflexos d'água para a construção, desconstrução de significados das obras ali expostas. O uso dos espelhos distribuídos pelo Instituto Inhotim se convergem e se refletem, transportando o público para o mundo paralelo da virtualidade, em cada reflexo, a cada selfie postado.

Baseando-se no conceito speculatio, derivado do termo latino Speculum, o espelho pode ser metáfora ou alegoria para um instrumento de conhecimento, pode apresentar conotações como ideia de mediação, cuja função é de auxiliar mediar o conhecimento de outra coisa. O espelho pode aumentar ou diminuir a imagem do objeto refletido, e não apenas reproduzi-la em seu tamanho real. Não se vê a imagem diretamente, vê-se através do espelho a imagem ou semelhança de algo. Além disso, no sentido figurado, o espelho tem acepção - algo que deixa transparecer alguma coisa, ou ainda, modelo a ser seguido (exemplo). Quando se olha no espelho, não se vê "o espelho em si mesmo", mas, sim a imagem de outra coisa refletida nele. Um duplo, outro lugar; visto que é da sua própria natureza refletir outra coisa. (SCHLITHELER, 2017, p. 98).

Após o percurso traçado por esta pesquisa, o lugar do espelho e o papel da instalação Folly, em Inhotim, apresentam-se com maior clareza. O espelho de Soares transporta o espectador para um tempo fragmentado. A arte interage com espectador, um universo maravilhosamente aconchegante e reflexivo através da arte contemporânea, onde se trabalha também com os sentidos. Ao mesmo tempo em que a imagem possibilita o conhecimento de si, torna possível uma espécie de alienação. À medida que os dançarinos flutuam dentro e fora do alcance do espectador, a melodia fraturada da música reflete sua incapacidade de se conectar uns com os outros. Relaciona-se à dança frenética dos grandes centros urbanos, em que mesmo inerente a uma multidão o indivíduo vive solitário.

A trilha The look of love se torna um espelho sutilmente quebrado, que preenche completamente o contínuo de espaço-tempo, suspenso dos dançarinos de Soares. À 
medida que esses corpos se movem e não se sincronizam entre si e com a trilha sonora, torna-se claro que eles não têm a capacidade de se conectar com os objetos desejados.

\begin{abstract}
O fantasma do espelho puxa para fora minha carne, e ao mesmo tempo todo o invisível de meu corpo pode investir os outros corpos que vejo. Doravante meu corpo pode comportar segmentos tomados do corpo dos outros assim como minha substância passa para eles, o homem é espelho para o homem. Quanto ao espelho, ele é o instrumento de uma universal magia que transforma as coisas em espetáculos, os espetáculos em coisas, eu em outrem e outrem em mim. Com frequência os pintores sonharam sobre os espelhos porque, sob esse "truque mecânico" como sob o da perspectiva, reconheciam a metamorfose do vidente e do visível, que é a definição da nossa carne e a da vocação deles (MERLEAU- PONTY, 2004, p. 23).
\end{abstract}

O dentro da obra é o oposto da parte externa; fora o amor é um convite, o encontro para se mirar no espelho; construir sua "pintura viva" em forma de selfies. $\mathrm{O}$ espectador se torna personagem de possibilidades fotográficas únicas. O espelho de Soares é passagem, demarca duas dimensões, dois lados do espelho, dentro e fora. Entretanto, o lado de dentro é o avesso do espelho, um convite para ver a face do amor que nunca se apresenta. Assim, como o espelho espreita e é espreitado na obra de Van Eyck e de Velásquez, o artista faz parte, o sujeito/pintor. Ele é a imagem, habilmente pintado, construído para compor cada "tableaux vivants" - a menção ao reflexo de Narciso, como suporte reflexivo da água. O reflexo Narcísico se projeta no artista que se revela na memória de quem o contempla. O espectador/sujeito ocupa a cena do ponto de vista do pintor, onde o espaço e o tempo são revelados no aqui e agora, tudo está acontecendo naquele momento, num eterno retorno. Tornar o espectador como o sujeito narcísico em relação ao olhar do outro, como reconhecimento de si, modifica a leitura de Narciso.

O fim de Narciso é a morte, seu erro está em se apaixonar por si mesmo, por não mudar de foco egóico. Todavia, o fim do espectador narcisista da obra Folly é o de vislumbrar a face do amor, do vazio que se desintegra nos excessos, dos novos suportes da arte. Numa via de mão dupla, a arte pode relançar a vida, os mitos, até de Narciso, às suas contradições, convocando-a a se rever, a se atualizar e a se reinventar. O Folly é um exemplo de que a arte procura quebrar os limites entre o espectador, obra é vivência. O sujeito é levado a abandonar-se no espaço que o envolve, interagindo com ele na interatividade virtual. Essa obra é pautada no jogo das imagens da sala do espelho, permeada de encontros e desencontros, criando a possibilidade de um sonho a dois - o público e o artista. 
Para concluir, não há o encontro, o amor não se encontra com a morte. Ele é diluído diante da atmosfera virtual, fugidia, criando uma possibilidade de um sonho a dois, espectador e artista, em forma de dançarinos que apenas se miram, sem a menor possibilidade de se tocarem. É possível pensar sobre essa obra como a primeira experiência do amor, comparando-o o primeiro espelho velado, tal como seja o rosto amado no espelho, no qual o espectador se olha e se confunde entre suas imagens e as do outro; o olhar sempre à espreita, encantado e desamparado diante do que há por vir. Sem qualquer garantia, só o abismo de um jogo de sombras e projeções. Em tempos passados, descobre-se que a face do rosto amado é só um rastro, que ora derruba com seus reflexos e imagens fugidias, escorregadias, ora as mãos somente tocam a superfície dos espelhos, mãos vazias. E só na lembrança permanecem imagens veladas que, a cada dia, desvelam e revelam um traço, uma lembrança de voz, um sorriso ou, ainda, um olhar. Apenas um jeito, uma pose capturada pela contemplação ou uma cena da qual nunca se tem uma presença verdadeiramente; um lugar inabitável, muito além da heterotopia de Foucault. 


\section{REFERÊNCIAS}

ADORNO, T. Indústria cultural e sociedade. São Paulo: Paz e Terra, 2000.

AGUIRRE, Ander e MUNAIN, Gorka. Hacia la Cultura Visual. In: AGUIRRE, Ander e MUNAIN, Gorka. Estúdio de la imagens, experiência, percepción, sentido(s). Santander: Shangrila, 2014.

ALMEIDA, Juliana Gisi Martins de. A virada do espelho no processo de reflexão. PUCPR Curitiba, 2004. Disponível em: <http://www.portalanpedsul.com.br/admin/uploads/2004/Painel/Painel/01_00_02_A_VI RADA_DO_ESPELHO_NO_PROCESSO_DE_REFLEXAO_E_A_ARTE.pdf> Acesso em: 10 out. 2017.

ALMEIDA, Rafael Goffinet de. Arte, arquitetura e cidade nas investigações de Dan Graham. São Carlos 2016. 256 p. [Dissertação/ Mestrado] (Teoria e História da Arquitetura e do Urbanismo.), USP.

AMARAL, Aracy. Espelhos e sombras. In: ESPELHOS e sombras. Apres. Eduardo A. Levy Jr. Texto de Aracy Amaral. São Paulo: MAM; Rio de Janeiro: Centro Cultural Banco do Brasil, 1994/1995.

ARCHER, M. Arte contemporânea: uma história concisa. São Paulo: Martins Fontes, 2013.

ARGAN, Giulio Carlo. Arte moderna. São Paulo: Companhia das Letras, 1993.

ARISTOTELES. A poética clássica. São Paulo: Cultrix:1997.

ARNHEIM, Rudolf. Arte e percepção visual: uma psicologia da visão criadora. São Paulo: Pioneira, 1994.

AUMONT, J. A imagem. Campinas. São Paulo: Papirus, 1993.

BACHELARD, Gaston. A água e os sonhos: ensaios sobre a imaginação da matéria. Trad. Antônio de Pádua Danesi. São Paulo: Martins Fontes, 1989.

BACHELARD, Gaston. A água e os sonhos: ensaio sobre a imaginação da matéria. Trad. Antônio de Pádua Danesi. São Paulo: Martins Fontes, 1998.

BARBON, Lilian Patrícia. O autorretrato fotográfico na arte contemporânea. Florianópolis, 2012. 195 f. Dissertação (Mestrado em Teoria e História da Arte)Universidade do Estado de Santa Catarina. 
BARTHES, Roland. A câmara clara: nota sobre a fotografia. Trad. Júlio Castañon Guimarães. Rio de Janeiro: Edições 70, 1984.

BAUDELAIRE, Charles. Sobre a modernidade. São Paulo: Paz e Terra, 2004.

BAUDRILLARD, J. A arte da desaparição. Rio de Janeiro: Ed. UFRJ, 1997.

BAUDRILLARD, J. A troca simbólica e a morte. Lisboa: Edições 70, 1976.

BAUDRILLARD, J. La transferência del mal ensayo sobre los fenômenos externos. Barcelona: Anagrama, 1991.

BAUDRILLARD, J. O sistema dos objetos. São Paulo: Perspectiva, 2004.

BAUDRILlARD, J. Simulacros e simulação. Trad. Maria João da Costa Pereira. Lisboa: Relógio d'água, 1991.

BAUDRILLARD, Jean. De la seducción. Madrid: Ediciones Cátedra, S.A.1981.

BAUDRILLARD, Jean. Tela total, mitos e ironias do virtual e da imagem. Porto Alegre: Sulina, 2005.

BAUDRILLARD, Jean. A arte da desaparição. Rio de Janeiro: UFRJ/ N, 1997.

BENJAMIN, Walter. A obra de arte na época de sua reprodutibilidade técnica. In: ADORNO et al. Teoria da Cultura de massa. Trad. de Carlos Nelson Coutinho. São Paulo: Paz e Terra, 2000, p. 221-254.

BERKELEY, George, A treatise concerning the principles of human knowledge, Londres, 1710. Philosophical Works. Londres: J. M. Dent \& Sons. 1975.

BERNARDO, Gustavo. O espelho de Flusser. Artefilosofia, Ouro Preto, n.14, julho 2013. Disponível em:<http://www.raf.ifac.ufop.br/pdf/artefilosofia_14/(171183)Gustavo_Bernardo-Flusser_e_Ressulf.pdf>. Acesso em 12 out. 2016.

BÍBLIA DE JERUSALÉM. São Paulo: Paulus, 2002.

BIENAL INTERNACIONAL DE SÃO PAULO, 22, 1994, São Paulo, SP. Catálogo Geral de Participantes. Curadoria Geral Nelson Aguilar. São Paulo: Fundação Bienal São Paulo, 1994.

BRAMLY, Serge. Leonardo da Vinci: (1452-1519). Rio de Janeiro: Imago, 1989.

BRONDO, Elsa. Vivian Maier Rodriguez, la mirada de autor y la mirada social. Acta poét [online]. 2013, vol.34, n.1, p.71-84. 
BURCKHARDT, Titus . La simbologia di Specchio. Centro di studi la Runa. 2015.

Disponível em: <https://www.centrostudilaruna.it/burckhardtsimbologiaspecchio.html>. Acesso em: 30 nov. 2017.

CACCIARI, Massimo. El espejo de Platón: Narciso, o de la pintura. In: El Dios que baila. Trad. de Virginia Gallo. $1^{\mathrm{a}}$ ed. Buenos Aires, Barcelona, México: Paidós, 2000, p. $57-69$ e $71-87$.

CALVINO, Ítalo. Se numa noite de inverno um viajante. Trad. Nilson Moulin. São Paulo: Companhia das Letras, 1999.

CARROLL, Lewis. Alice - aventuras de Alice no País das Maravilhas \& através espelho e o que Alice encontrou por lá. Trad. Maria Luiza X. de A. Borges. Rio de Janeiro: Zahar, 2010.

CAVAlCANTI, Raïssa. O mito de Narciso: o herói da consciência. São Paulo: Cultrix, 1992.

CAUQUELIN, Anne. Arte Contemporânea: uma introdução. São Paulo: Martins Fontes, 2005.

CHAUÍ, M. Introdução à história de filosofia: dos pré-socráticos a Aristóteles, vol. 1; 2.ed., ver. e ampl. São Paulo: Companhia das Letras, 2002.

COHN, Maria Cecília Falcão Mendes. Selfie, a cultura do espelho: No Espelho? In: CCLACC Centro de Estudos Latino Americanos de Cultura e Comunicação. São Paulo, p. 1-40, 2015. Disponível em: http://paineira.usp.br/celacc/?q=ptbr/tcc_celacc/selfie-cultura-espelho-espelho. Acesso em: 04 jun. 2018.

CONTE, Bernadete. Um uso do espelho como estratégia pictórica: uma anamorfose no campo da visão para a inclusão do espectador no campo da representação. SIG Revista de Psicanálise. Lisboa. p.55-66, 2013. Disponível em: http://sig.org.br/wpcontent/uploads/2016/04/Num3_Site-Art5.pdf. Acesso em: 03 jun. 2018.

DEBORD, Guy. A sociedade do espetáculo. Comentários sobre a sociedade do espetáculo. Rio de Janeiro: Contraponto, 1997.

DANTO, Arthur C. Após o fim da arte. São Paulo: Odysseus, 2006

DERRIDA, Jacques. La pharmacie de Platon. In: La dissémination. $1^{\text {a }}$ ed. Paris : Éditions du Seuil, 1972, p. 77-213. 
DIDI-HUBERMAN, G. O que vemos, o que nos olha. Trad. Paulo Neves. São Paulo: Ed. 34, 2010.

DUBOIS, Philippe. O ato fotográfico e outros ensaios. Campinas: Papirus, 1994.

ECO, Umberto. Sobre os espelhos e outros ensaios. Rio de Janeiro: Nova Fronteira, 1989.

ESCHER, Maurits Cornelis. Hand with Reflecting Sphere. Wikipédia . Disponível em : https://en.wikipedia.org/wiki/Hand_with_Reflecting_Sphere, acesso em: 04 jun. 2018. ÉSQUILO, Ishtmiastase, versos 5-21 do fragmento 1.

FERNANDES, Rodrigo Pereira. O Corpo Neobarroco em De Lama Lâmina, de Matthew Barney. 2016. 108f. Dissertação (Mestrado em História da Arte) Universidade Federal de São Paulo, Escola de Filosofia, Letras e Ciências Humanas, Guarulhos, 2016.

FLUSSER, Viliem. Do espelho. Disponível em: https://www.scribd.com/doc/57238668/Do-Espelho-Vilem-Flusser. Acesso em out. 2015.

FLUSSER, Vilém. Do espelho. In: Ficções filosóficas. São Paulo: EDUSP, 1998, p. 171-176.

FLUSSER, Vilém. Filosofia da caixa preta: ensaios para uma futura filosofia da fotografia. Rio de Janeiro: Relume Dumará, 2002.

FOUCAULT, M. De espaços outros. Estudos Avançados, v. 27, n. 79, p. 113-122, 1 jan. 2013.

FREITAS, Klix N. Representação, simulação, simulacro e imagem na sociedade contemporânea. Polêmica, 12, jun. 2013. Disponível em: <http://www.epublicacoes.uerj.br/index.php/polemica/article/view/6435/4861>. Acesso em: 10 out. 2017.

GOMBRICH, E. H. The story of art. London: Phaidon Press Limited, 2006.

GREEN, J. R., Theatre. In: Ancient Greek society. Londres/Nova York: Routledge, 1994.

GRIMAL, P. Dicionário de mitologia grega e romana. Rio de Janeiro: Bertrand Brasil, 2000. 
HAN, Byung Chul. A Sociedade do Cansaço. Tradução de Enio Paulo Giachini. Rio de Janeiro: Vozes, 2015.

Byung Chul. A Sociedade da Transparência. Relógio D’água Editores, Lisboa, 2014.

Filósofo Germano-Coreano Byung-Chul Han contra a civilização do "Curtir". Disponível: <http://ghiraldelli.pro.br/filosofia-social/filosofo-germano-coreano-byungchul-han-contra-civilizacao-curtir.html>. Acesso em: 03 Out. 2017.

HARLEY, David. A condição pós-moderna. São Paulo :Loyola, 1992.

LASCH, Christopher. A cultura do Narcisismo. Rio de Janeiro: Imago editora, 1983.

LIPOVETSKY. Gilles. A felicidade paradoxal. Ensaio sobre a sociedade de hiperconsumo. São Paulo: Companhia das Letras, 2007.

A Era do Vazio: um ensaio sobre o individualismo contemporâneo. São Paulo: Manole, 2005.

HICKSON, Patricia. Valeska Soares: Matrix 176 Unfold. Wadsword Atheneum Museum of Art. Hartford: 02 fev. a 07 mai. 2017. Disponível em: $<$ https://www.thewadsworth.org/exhibitions/valeska-soares-matrix-176/> Acesso em : 27 ago. 2019.

HOFFMANN, Jens e TAXTER, Kelly. Valeska Soares. Milan: Mousse Publishing/ Rio de Janeiro: Cobogó, 2016 .

INSTITUTO BRASILEIRO DE MUSEUS (IBRAM). Os museus. 2008. Disponível em: http://www.museus.gov.br/os-museus/. Acesso em: 25 de jun. 2018.

INSTITUTO INHOTIM. Museu de Arte Contemporânea e Jardim Botânico. Disponível em: <https://www.inhotim.org.br>. Acesso em 18 de out. 2019.

INSTITUTO MOREIRA SAlles. Os Parangolés de Hélio Oiticica: De: Hélio Oiticica Para: Jayme Maurício. Correio ISM. São Paulo, 2017. Disponível em: <https://www.correioims.com.br/carta/os-parangoles-de-helio-oiticica/>. Acesso em: 4 dez. 2017

LACAN, Jacques. O estádio do espelho como formador da função do eu. In: ZIZEK, Slavoj (org.). Um mapa da ideologia. Rio de Janeiro: Contraponto, 1996. p. 97-103. 
LAENAERS , Sylvia Cases. El espejo como reflejo do los mundos de la enajenación em el art. In: I Congreso sobre arte, literatura y cultura gótica urbana, celebrado en octubre de 2012 en la Universidad Autónoma de Madrid, 2013, Madrid. Herejía y belleza 1 (2013): 139-149.

LOVELOCK, James. A vingança de Gaia. São Paulo . Intrínseca, 2006.

MACHADO, A. Pré-cinemas e pós-cinemas. Campinas: Papirus, 1997.

MARCHAND, Bruno. Jorge Molder. Chiado 8 Arte Contemporânea, 2002.

MAYER; Ralph. Manual do artista. Martins Fontes; 1950; 1957 e 1970.

MOTTA, Edson e SALGADO, Maria. Iniciação a pintura. São Paulo: Nova Fronteira, 1976.

MEDEIROS, Margarida. Fotografia e narcisismo. O autorretrato contemporâneo, Lisboa: Assírio \& Alvim, 2000.

MEIRELES, Cecília. Discurso ao ignoto romano. In: Poemas italianos. São Paulo: Abril, 1953. Disponível em: http://ceciliameireles2009.blogspot.com/2014/06/discursoao-ignoto-romano.html, acesso em: 30 jun. 2018.

MELLO, Paulo Cezar Barbosa. Site Specificity na arte contemporânea: Inhotim. 2015. Tese (Doutorado em Teoria, Ensino e Aprendizagem) - Escola de Comunicações e Artes, Universidade de São Paulo, São Paulo, 2015. doi:10.11606/T.27.2015.tde29062015-151300. Acesso em: 2018-09-17.

MELLO, H. A cultura do simulacro: filosofia e modernidade em Jean Baudrillard. São Paulo: Loyola, 1998.

MELO, Alexandre. Jorge Molder - Retratos, conversar, fragmentos. In: Arte Ibérica, $\mathrm{n}^{\mathrm{o}} 25$, jun. 1999.

MELLO. Nô. The day after. Joia de Artista- Valeska Soares. VOGUE. São Paulo., n. 481, set., 2018. Disponível em : < http://fdag.com.br/artistas/valeska-soares/> Acesso em: 04 ago. 2019.

MERLEAU-PONTY, M. Fenomenologia da percepção. São Paulo: Martins Fontes, 1999.

MOLDER, Jorge. Um dia cinzento. Porto: Assírio \& Alvim, 1983. 
MORENTE, Manuel Garcia. Fundamentos de filosofia. Noções preliminares. In: Lição IV. Disponível em:< http://www.consciencia.org/fundamentosfilosofiamorente6.shtml $>$ Acesso em: 10 out. 2017.

MORI, Fabiana Miano. A construção da imagem em o espelho in primeiras estórias de João Guimarães Rosa e em las meninas de Pablo Picasso. Araraquara, 2007, 97f. Dissertação (Mestrado em Estudos Literários - Relações Intersemióticas), Faculdade de Ciências e Letras da Universidade Estadual Paulista "Júlio de Mesquita Filho".

MUCCI, Latuf Isaias. Nascemos todos e vivemos sob o mesmo signo do simulacro. Disponível em: https://pendientedemigracion.ucm.es/info/especulo/numero35/nascemos.html>. Acesso em: 10 out. 2017.

NOVAES, Adalto et al. O olhar. São Paulo: Companhia das Letras, 1998.

NEPOMUCEnO, M. A arte mágica do indiano Anish Kapoor em São Paulo. São Paulo, 05, jan. 2007. Disponível em : < http://cartamaior.com.br/?/Editoria/Midia/Aarte-magica-do-indiano-Anish-Kapoor-em-Sao-Paulo/12/12683>. Acesso em 28 Nov. 2017.

OLIVEIRA, Ana Rosa de. Roberto Burle Marx. Entrevista, São Paulo, ano 02, n. 006.01,Vitruvius, abr., 2001<http://www.vitruvius.com.br/revistas/read/entrevista/02.006/3346>.

OVÍDIO. Metamorfoses III, 405-510. São Paulo: Ars Poética, 1998.

PAZ, Bernardo. Através: Inhotim centro de arte contemporânea. Brumadinho: Instituto Inhotim, 2008 (catálogo do acervo).

PEDROSA, Adriano. Valeska Soares. Belo Horizonte: Museu de Arte da Pampulha, 2002.

PEDROSA, Adriano (org.). Valeska Soares, ponto de fuga, desaparecimento. São Paulo: Galeria Camargo Vilaça, 1999.

PEDROSA, Adriano. Histórias. São Paulo: Galeria Camargo Vilaça, 1996.

PIETROFORTE, A. Semiótica visual: os percursos do olhar. São Paulo: Contexto, 2004. 
PLATÃO, Diálogos. A república (ou sobre a justiça. Gênero político). Trad. Carlos Alberto Nunes. $3^{\text {a }}$ ed. Belém: EDUFPA, 2000.

PRENSKY, Marc. Nativos Digitais, Imigrantes Digitais. On the Horizon. NCB University Press, Vol. 9 No. 5, out. 2001. Disponível em http://www.colegiongeracao.com.br/novageracao/2_intencoes/nativos.pdf. Acesso em 20 jul. 2018.

ROSA, Guimarães. O espelho. In: Primeiras estórias, São Paulo: Nova Fronteira, 2005.

SANTAELLA, L. Imagem: cognição, semiótica, mídia. São Paulo: Iluminuras, 1997.

SANTOS, F. H. Metodologia aplicada em Museus. São Paulo: Mackenzie, 2000.

SERAPIÃO, Fernando. Inhotim: arquitetura, arte e paisagem. São Paulo: Monolito, 2015 .

SCHEINER, Tereza Cristina. Repensando o museu integral: do conceito às práticas. Boletim do Museu Paraense Emílio Goeldi. Ciências Humanas, v. 7, n. 1, p. 15-30, jan.-abr. 2012.

SCHLITHELER, Fernando da F. C. A contemplação de Deus no espelho da Música: a música especulativa no tratado Speculum Musicae. Um estudo sobre a música speculativa medieval e seu contexto filosófico e teológico a partir da leitura dos capítulos introdutórios de Livro I do tratado Speculum Musicae (c. 1340). Dissertação (mestrado) - Escola de Comunicações de Artes, Universidade de São Paulo. São Paulo, 2017.

SITE Specific. In: ENCICLOPÉDIA Itaú Cultural de Arte e Cultura Brasileiras. São Paulo: Itaú Cultural, 2019. Disponível em: $<$ http://enciclopedia.itaucultural.org.br/termo5419/site-specific>. Acesso em: 29 de Nov. 2019. Verbete da Enciclopédia. ISBN: 978-85-7979-060-7.

SOARES, Valeska. Valeska Soares. Texto de Adriano Pedrosa. São Paulo: Galeria Camargo Vilaça, 1996.

SOARES, Valeska. Valeska Soares. Texto de Charles Merewether. São Paulo: Galeria Camargo Vilaça, 1994. 
SOARES. Valeska. Invenção, Memória, Sonho. Texto de Moacir dos Anjos. Recife: Fundação Joaquim Nabuco, Instituto de Cultura, 2004. 32 p. il. (Projeto Visualidades Contemporâneas).

SOARES, Valeska. Follies/Capricho. New York: The Bronx Museum of the Arts; Monterrey: Museo de Arte Contemporáneo de Monterrey; Ontario: Art Gallery of Hamilton, 2005.

SOARES, Valeska Entrementes. São Paulo: Pinacoteca de São Paulo, 2018 (catálogo de exposição).

SOARES, Valeska; MEIRELES, Cildo; NETO, Ernesto. Seduções. Zürich: Hatje Cantz, 2006.

SPEAKE, Jeniffer. Dictionary of proverbs Oxford. $6^{\text {a }}$ ed. United Kingdom: Oxford University Press, 2015.

SPECTOR, N. Sobre Robert Smithson. Disponível em: < http://www.guggenheim.org/new-york/collections/collection-online/artwork/5322>. Acesso em 28 nov. de 2017.

STEIN, Helga. Helga Stein: vertigens documentais. Disponível em: $<$ http://ederchiodetto.com.br/portfolio-helga-stein-texto-do-curador/>Acesso em: 23 jun. 2017.

STEVENSON, Robert Louis. O estranho caso do Dr. Jekyll e do Sr. Hyde. In: O estranho caso do Dr. Jekyll e do Sr. Hyde e outros contos. Trad. pref. e notas de Jorge Pereirinha Pires. $1^{\text {a }}$ ed. Lisboa: Assírio \& Alvim, 2007, p. 103-198.

SHUWARTZMAN, Allan. Um lugar a se conhecer. In: MOURA, Rodrigo; PEDROSA, Adriano (org.). Através: Inhotim, Centro de Arte Contemporânea. Brumadinho: Instituto Cultural Inhotim, 2008, p. 22-29.

TABACOW, José (org.). Roberto Burle Marx: arte \& paisagem (conferências escolhidas). São Paulo: Studio Nobel, 2004.

VALESKA Soares. In: ENCICLOPÉDIA Itaú Cultural de Arte e Cultura Brasileiras. São Paulo: Itaú Cultural, 2019. Disponível em: <http://enciclopedia.itaucultural.org.br/pessoa10770/valeska-soares>. Acesso em: 31 de Jul. 2019. Verbete da Enciclopédia. ISBN: 978-85-7979-060-7 
VIGNA, Carolina. Análise de uma obra de arte : os esposos Arnolfini. São Paulo, 2009. Disponível em: <http://carolina.vigna.com.br/analise-de-uma-obra-de-arte-osesposos-arnolfini/>. Acesso em: 02 dez. 2017.

WISNIK, Guilherme. O dentro é fora. O outro que sou eu. In: ELIASSON, Olafur. Your body of work. Seu corpo da obra. São Paulo: SESC, 2011.

ZAFRA, Rafael. Emblematura aurea. Madrid: Editorial Akal, 2000. 
ANEXOS

\section{I - Biografia e cronologia de exposições ${ }^{25}$}

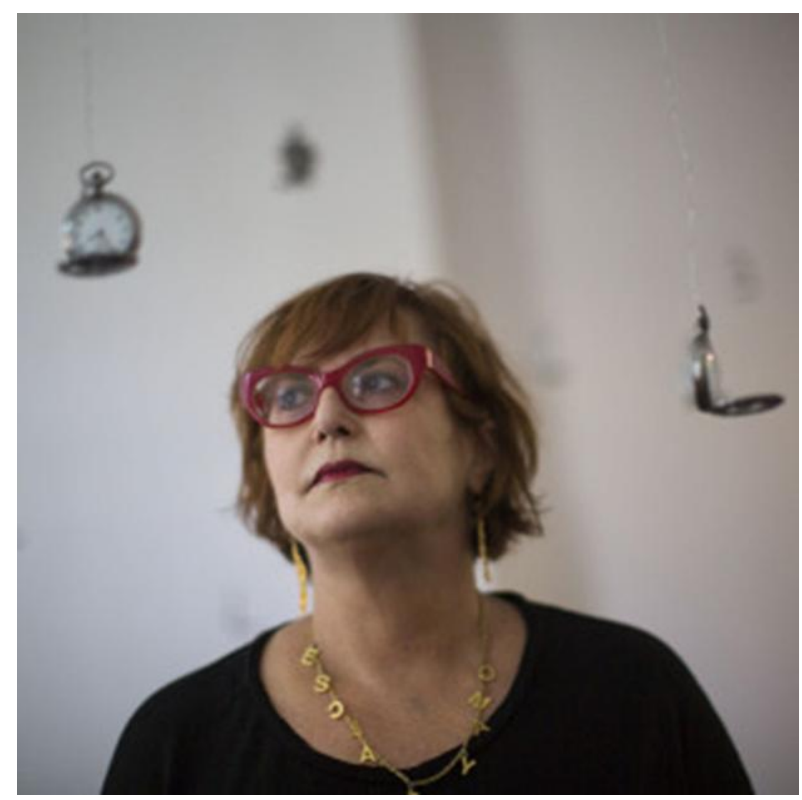

Valeska Soares. São Paulo, 2018. Instituto Inclusartiz. Fonte: http://inclusartiz.org/valeska-soares/.Acesso em: 18 abr. 2019.

\section{Biografia}

Vive e trabalha no Brooklyn, NY, desde 1992.

1957 Nasce em Belo Horizonte, Brasil, 1957.

1987 Bacharel em Arquitetura, Universidade Santa Úrsula, Rio de Janeiro.

1990 Diploma de especialização em pós-graduação em História da Arte e Arquitetura, Pontifícia Universidade Católica, Rio de Janeiro.

1994 Mestrado em artes, Pratt Institute. Nova York.

E Ph.D. em Artes, New York University, Nova York.

\section{Exposições Individuais}

2018 Entrementes, Estação Pinacoteca, São Paulo, Brasil.

Any Moment Now, Phoenix Museum, Phoenix, USA.

\footnotetext{
${ }^{25}$ VALESKA Soares. In: ENCICLOPÉDIA Itaú Cultural de Arte e Cultura Brasileiras. São Paulo: Itaú Cultural, 2019. Disponível em: 〈http://enciclopedia.itaucultural.org.br/pessoa10770/valeska-soares〉. Acesso em 16 nov. 2019. Verbete da Enciclopédia. ISBN: 978-85-7979-060-7
} 
2017 Unfold, Wadsworth Atheneum Museum of Art, Hartford, USA.

Any Moment Now, Santa Barbara Museum of Art, Santa Barbara, USA.

Neither Here Nor There, Alexander Gray Associates, New York, USA.

Valeska Soares: Matrix 176 Unfold, Wadsworth Atheneum, Hartford, USA.

2016 Lugar Comum, Galeria Fortes Vilaça, São Paulo, Brasil.

2015 Time Has No Shadows, The Jewish Museum, New York, USA.

2014 Any Moment Now..., Eleven Rivington Gallery, New York, USA.

Double Margin, Max Wigram Gallery, London, UK

2013 Notations, Max Wigram Gallery, London, UK

Push Pull, produced by Kreemart for the Cisneros Fontanals Art Foundation, Miami, Florida

2012 Paragraphs, Galeria Fortes Vilaça, São Paulo, Brasil.

Bindings, Eleven Rivington Gallery, New York, USA.

2010 Vaga Lume, Eleven Rivington Gallery, New York, USA.

Passa Tempo, Greenberg Van Doren Gallery, New York, USA.

2009 Passa Tempo, Galpão Fortes Vilaça, São Paulo, Brasil.

2008 After, Eleven Rivington Gallery, New York, USA.

2007 After, Galeria Fortes Vilaça, São Paulo, Brasil.

2006 Walk on by, Art Gallery of Hamilton, Ontário, Canadá

2005 nar-cis-sus, Galeria Fortes Vilaça, São Paulo, Brasil nar-cis-sus, Vitamin Arte Contemporanea, Turin, Italy Notations, Fusebox, Washington DC, USA.

2003 Follies, The Bronx Museum of the Arts, New York, USA, itinerou como Caprichos to MARCO - Museo de Arte Contemporáneo de Monterrey, Monterrey, México.

Centro Dragão do Mar de Arte e Cultura, Fortaleza, Brasil.

Puro Teatro, Museo Rufino Tamayo, Mexico City, México.

2002 Mirrorings, Dwight Hackett Projects, Santa Fe, USA.

Fundação Joaquim Nabuco, Recife, Brasil.

Détour, Galeria Fortes Vilaça, São Paulo, Brasil. 
Museu de Arte da Pampulha, Belo Horizonte, Brasil.

1999 Vanishing Point, Museum of Contemporary Art San Diego, La Jolla, USA.

Projeto FINEP, Paço Imperial, Rio de Janeiro, Brasil.

Galerie Claudine Papillon, Paris, France

1998 Vanishing Point, Galeria Camargo Vilaça, São Paulo, Brasil.

Vanity, Portland Institute of Contemporary Art, Portland, USA.

Histórias, um projeto para the Public Art Fund, New York, USA.

Untitled (from Vanishing Point) 1998, new installation, Christopher Grimes Gallery, Santa Monica, USA.

1997 Personagens, Galeria Luis Adelantado, Valencia, Spain.

1996 Strangelove, Galeria Camargo Vilaça, São Paulo, Brasil.

Seen/Unseen, Laumeier Sculpture Park and Museum, Saint Louis, USA.

Untitled (from Vanishing Point), Christopher Grimes Gallery, Santa Monica, USA.

1995 Discontinuous Teasers, The New Museum of Contemporary Art, New York, USA.

1994 Fall, Galeria Camargo Vilaça, São Paulo, Brasil.

Information Gallery, New York, USA.

1992 Centro Cultural São Paulo, São Paulo, Brasil.

1991 Centro Cultural Sergio Porto, Rio de Janeiro, Brasil.

\section{Exposições Coletivas}

2018 Mundo Vasto Mundo, Fortes D’Aloia \& Gabriel | Escritório Lisboa, Lisboa, Portugal

Gaze, Greenberg Van Doren Gallery, New York, USA.

201799 Cents or Less, Museum of Contemporary Art, Detroit, USA.

Jardin infini. De Giverny à l'Amazonie, Centre Pompidou-Metz, Metz, France

Half-Life of Love, MassMOCA, North Adams, USA.

Past/Future/Presente: Contemporary Brazilian Art from the Museum of Modern Art, São Paulo, Phoenix 
Museum of Art, Phoenix, USA.

Ainda Esculturas, Espaço Auroras, São Paulo, Brasil.

Out of Sight! Art of the Senses, Albright Knox Art Gallery, New York, USA.

2016 Brasil, Beleza?, museum Beeldenaan Zee / Lange Voorhout, Den Haag, Netherlands

Gestos iconoclastas, imágenes heterodoxas, CaixaForum, Barcelona, Spain.

Tertúlia, Galeria Fortes Vilaça, São Paulo, Brasil.

Clube de Gravura - 30 Anos, MAM - Museu de Arte Moderna de São Paulo, São Paulo, Brasil.

2015 Belle Haleine - The Scent of Art, Museum Tinguely, Basel, Switzerland Blueprint 2.0, Storefront for Art and Architecture, New York, USA.

O Espírito de Cada Época, Instituto Figueiredo Ferraz, Ribeirão Preto, Brasil.

Rotation 2: Contemporary Art from the Peter Norton Gift, Kemper Art Museum, St. Louis, USA.

By the book, Sean Kelly Gallery, New York, USA.

PICA: Celebrating 20 Years, Reflecting on the First Decade, Elizabeth Leach Gallery, Portland, USA.

Afetividades Eletivas, Centro Cultural Minas Tênis Clube, Belo Horizonte, Brasil.

2014 One Another: Spiderlike, I Spin Mirrors, Albright-Knox Gallery, Buffalo, New York

Push Pull, performance que coincide com a exposição.

Permission to Be Global, Cisneros Fontanals Art Foundation, Miami, USA.

A Tara por Livros ou a Tara de Papel, Galeria Bergamin, São Paulo, Brasil.

Blueprint 2.0, Kunsthal KAdE, Amersfoort, Netherlands; Museum of Contemporary Art Tucson, Tucson, USA.

Unbound: Contemporary Art After Frida Kahlo, Museum of Contemporary Art Chicago, Chicago, USA.

Pinacoteca de São Paulo visita O MAC de Sorocaba, MACS - Museu de Arte Contemporânea de Sorocaba, Sorocaba, Brasil. 
2013 Order, Chaos, and the Space Between, Contemporary Latin American Art from the Diane and Bruce Halle

Collection, Phoenix Art Museum, Phoenix, USA.

Qué Hacer, Fundació LaCaixa, Barcelona, Spain.

Commercial Break, Anonymous Gallery, Mexico DF, México.

On Painting, CAAM - Centro Atlántico de Arte Moderno, Las Palmas de Gran Canaria, Spain.

Los habladores: narrativas en el arte contemporâneo internacional, Arte y Numismática Museos del Banco de la República, Bogotá, Colômbia.

Permission to be Global: Latin American Art from the Ella Fontanals-Cisneros, CIFO - Cisneros Fontanals Art Foundation, Miami, USA.

Chick Lit: Revised Summer Reading, Tracy Williams Ltd, New York, USA.

2012 Repeat to Fade, Galeria Mendes Wood, São Paulo, Brasil.

The Storytellers, Narratives in International Contemporary Art, Stenersen Museum, Oslo, Norway

Text in Process, RH Gallery, New York, USA.

Read, Look! We promise it's not dangerous, Emily Harvey Foundation, New York, USA.

Inter Ruption: A Break in the Continuity of the Interstitial Space, Michael Kohn Gallery, Los Angeles, USA.

Weights and Measures, Eleventon Rivington Gallery, New York, USA.

2011 Commercial Break, 54th International Venice Biennale, Venice, Italy

Zona Letal, Espaço Vital: Obras da Colecção da Caixa Geral de Depósitos, Museu de Arte Contemporânea de Elvas; Museu Municipal de Tavira/ Palácio de Galeria, Tavira; Museu da Imagem em Movimento, Leiria, Portugal

P(art)ners: Gifts from the Heather and Tony Podesta Collection, The National Museum of Women in the Arts, Washington DC, USA.

Tablet, Eleven Rivington Gallery, New York, USA.

Tonight, projeção no Bring to Light Festival, Nuit Blanche NY 2011, Greenpoint ,USA.

Walk on by installation at Flash: Light, New Museum, New York, USA. 
8 a Bienal do Mercosul, Fundação Bienal de Artes Visuais do Mercosul, Porto Alegre, Brasil.

Everything Must Go: A Project With Cerámica Suro Guadalajara, Mexico; Casey Kaplan Gallery, New York, USA.

Afterlife, Cemetery De Nieuwe Ooster, Amsterdam, Netherlands

2010 Desire, Blanton Museum of Art, Austin, USA.

Models Kits: Thinking Latin America From Musac's Collection, MUSAC, Museo de Arte Contemporáneo de Castilla y León, León, Spain.

Santiago, punto de encuentro: Obras maestras de la Catedral y Caixa Galicia, Fundación Caixa Galicia, Santiago de Compostela, Spain.

Guatavita, Eleven Rivington Gallery, New York, USA.

Superfícies del Deseo, The University Museum of Contemporary Art, Mexico City, México.

Arte e Política: Outros Olhares, Museu de Arte de Ribeirão Preto, Ribeirão Preto, Brasil..

S, M, L, Greenberg Van Doren Gallery, New York, USA.

2009 Follies, Inhotim Centro de Arte Contemporânea, Brumadinho, Brasil.

Sharjah Biennial 9 - Provisions for the Future, Sharjah, United Arab Emirates $2^{\text {a }}$ Trienal Poli/Gráfica de San Juan: América Latina y el Caribe, Instituto de Cultura Puertorriqueña Antiguo.

Arsenal de la Marina Española, San Juan, Puerto Rico.

Nus, Galeria Fortes Vilaça, São Paulo, Brasil.

The Second Hand, Engholm, Vienna, Austria.

Just What Are They Saying, Jonathan Ferrara Gallery, New Orleans, USA.

The Order of Things: Revolutions of the Ordinary, Museum Morsbroich, Leverkusen, Germany

The Communism of Forms, Red Bull 381 Projects, Toronto, Canadá.

Experiências Contemporâneas - Coleção Marcantonio Vilaça no MAC USP, Espaço Cultural Marcantonio Vilaça, Brasília, Brasil.

Um Mundo sem Molduras, MAC USP - Museu de Arte Contemporânea da Universidade de São Paulo, São Paulo, Brasil. 
Private Universes, Dallas Museum of Art, Dallas, USA.

2008 Em Vivo Contato, 28a Bienal de São Paulo, Fundação Bienal de São Paulo, São Paulo, Brasil.

Stream of Forgotten Memories, OK Offenes Kulturhaus OÖ / OK Center of Contemporary Art, Linz, Austria

Arte Contemporânea Brasileira - Doação Credit Suisse, Estação Pinacoteca, São Paulo, Brasil.

Procedente-MAP: Novas Aquisições, Museu de Arte da Pampulha, Belo Horizonte, Brasil.

Defining a Moment, 54 Crosby Street, New York, USA.

Private Passions, Public Visions - Collections D. O. Galicia, MARCO - Museu de Arte Contemporánea de Vigo, Vigo, Spain.

It is Not Neutral: Daros Latin American Collection, Centro de Cultura Contemporánea Tabakalera, San Sebastián, Spain.

2007 Fit To Print, Gagosian Gallery, New York, USA.

Places, Luxe Gallery, New York, USA.

Re-materialized, Michael Benevento Gallery, Los Angeles, USA.

The Shapes of Space, Solomon R. Guggenheim Museum, New York, USA.

Itaú Contemporâneo: Art in Brazil from 1981- 2006, Instituto Itaú Cultural, São Paulo, Brasil.

2006 Seduções, Daros Latin America, Zurich, Switzerland.

Paralela 2006, Pavilhão Armando de Arruda Pereira, São Paulo, Brasil.

Venice-Istanbul: A Selection from the 51t International Venice Biennale, Istanbul, Turkey

Clube da Gravura: 20 Anos, MAM - Museu de Arte Moderna de São Paulo, São Paulo, Brasil.

Everybody Dance Now, Elizabeth Foundation for the Arts Gallery, New York, USA.

TRANSactions: Contemporary Latin American and Latino Art, The Museum of Contemporary Art San Diego, San Diego, USA.

Walk on By, Instituto Inhotim, Brumadinho, Brasil. 
Dirty Yoga: Taipei Biennial 2006, Tapei, Taiwan

Sublime Embrace: Experiencing Consciousness in Contemporary Art, Art Gallery of Hamilton, Ontario, Canadá.

2005 Always a Little Further, 51. Biennale di Venezia, Venice, Italy

Inverting the Map: Latin American Art from the Tate Collection, Tate Liverpool, Liverpool, UK

Landmark, 10 years of making the world safe for contemporary art, Portland Institute for Contemporary Art, Portland ,USA.

Anthology of Art Project, Zentrum für Kunst und Medientechnologie, Karlsruhe, Germany

Material Terrain: A Sculptural Exploration of Landscape and Place, Laumeier Sculpture Park and Museum, St.

Louis; Santa Cruz Museum of Art and History at McPherson Center, Santa Cruz; Palm Springs Museum, Palm

Springs; Arizona State University, Arizona; The Amarillo Museum of Art, Amarillo; Memphis Brooks Museum of Art, Memphis; Herron School of Art, Indiana University Purdue University, Indianapolis; Cheek wood.

Botanical Garden and Museum of Art, Nashville; Columbia Museum of Art, Columbia; Lowe Art Museum,

University of Miami, Miami, USA.

Draw, Dwight Hackett Projects, Santa Fe, USA.

Glass, Seriously, Dorsky Gallery, New York, USA.

En las Fronteras / In the Borderlands, Instituto Cervantes, Prague, Czech Republic; Instituto Cervantes in

Stockholm, Moscow, Berlin, Brussels and Granada

RAMPA: Signaling New Latin American Art Initiatives, Arizona State University Art Museum, Phoenix, USA.

Hair Raising, San Jose Institute of Contemporary, San Jose, USA.

2004 Material as Metaphor, Tanya Bonakdar Gallery, New York, USA.

Non Toccare la Donna Bianca: Arte Contemporanea fra Diversità e Liberazione, Fondazione Sandretto Rebaudengo, Turin, Italy

Anthology of Art Project, Martin-Gropius-Bau, Berlin, Germany 
Estratégias Barrocas: Arte Contemporânea Brasileira, Centro Cultural Metropolitano, Quito, Equador

Flowers Observed, Flowers Transformed, The Andy Warhol Museum, Pittsburgh USA.

The World Becomes a Private World: Selections from the Collections of Cooper and Rena Rosenwasser, Mills College Art Museum, Oakland, USA.

Third Liverpool Biennial, Liverpool, UK

Novas Aquisições 2003: Coleção Gilberto Chateaubriand, MAM - Museu de Arte Moderna do Rio de Janeiro, Rio de Janeiro, Brasil.

25th Anniversary, Cristopher Grimes Gallery, Los Angeles, USA.

Paralela 2004, São Paulo, Brasil.

Natureza Morta/Still Life, Galeria de Arte do Centro Cultural FIESP, São Paulo, Brasil.

Soirée Prospectif Cinéma, Centre George Pompidou, Paris, France

Bazar de Verão, Galeria Fortes Vilaça, São Paulo, Brasil.

2003 Marcantonio Vilaça: Passaporte Contemporâneo, MAC USP - Museu de Arte Contemporânea da Universidade de São Paulo, São Paulo, Brasil.

Mirror Tenses: Conflating Time and Presence, University Gallery, University of Massachusetts, Amherst, USA.

Pegadas de Luz/Huellas de Luz/Traces of Light, Centro Galego de Arte Contemporânea, Santiago de Compostela, Spain.

2002 poT, Galeria Fortes Vilaça, São Paulo, Brasil.

Lateral Thinking: Art of the 1990s, Museum of Contemporary Art San Diego, La Jolla, USA.

Arquitecturas de Interior, Galería Fúcares, Madrid, Spain.

Caminhos do Contemporâneo 1952-2002, Paço Imperial, Rio de Janeiro, Brasil.

Paralelos: Arte Brasileira da Segunda Metade do Século XX em Contexto:

Colección Cisneros, MAM - Museu de Arte Moderna de São Paulo, São Paulo;

MAM - Museu de Arte Moderna do Rio de Janeiro, Rio de Janeiro, Brasil.

Arte brasileño de hoy, Sala de Armas, Ciudadela, Pamplona, Spain.

20 Artistas/20 Anos, Centro Cultural São Paulo, São Paulo, Brasil. 
2001 Before Reflection Begins, David Winton Bell Gallery, Brown University, Providence, USA.

Elusive Paradise, National Gallery of Canada, Ottawa, Canadá.

F(r)icciones, Museo Nacional Centro de Arte Reina Sofía, Madrid, Spain.

Brooklyn!, Palm Beach Institute of Contemporary Art, Lake Worth, USA.

Arcadia, National Gallery of Canada, Ottawa, Canadá.

Espelho Cego: Seleções de uma Coleção Contemporânea, Paço Imperial, Rio de Janeiro, Brasil.

O Espírito de Nossa Época, MAM - Museu de Arte Moderna de São Paulo, São Paulo, Brasil.

Rotativa Fase 1, Galeria Fortes Vilaça, São Paulo, Brasil.

2000 inSITE2000-01, San Diego, USA; Tijuana, México.

Ultrabaroque: Aspects of Post-Latin American Art, Museum of Contemporary Art San Diego, La Jolla, USA.

Modern Art Museum of Fort Worth, Forth Worth; San Francisco Museum of Modern Art, San Francisco, USA.

Art Gallery of Ontario, Toronto, Canada; Miami Art Museum; Walker Art Center, Minneapolis, USA.

"Good Business is the Best Art": Twenty Years of the Artist in the Marketplace Program, The Bronx Museum of the Arts, New York, USA.

Greater New York, P.S.1 Contemporary Art Center, New York, USA.

Brasil: Plural y Singular, Museo de Arte Moderno, Buenos Aires, Argentina.

XII Mostra da Gravura da Cidade de Curitiba: Marcas do Corpo, Dobras da Alma, Museu Metropolitano de Arte, Curitiba, Brasil.

Shoes, TZ Art Gallery, New York, USA.

A Forma e os Sentidos um Olhar sobre Minas, Museu Ferroviário Vale do Rio Doce, Vila Velha, Brasil.

Virgin Territory: Women, Gender, and History in Contemporary Brazilian Art, National Museum of Women in the Arts, Washington DC, USA.

1999 Dobles Vides, Museu Marítim de Barcelona, Barcelona, Spain. 
Amnesia, Christopher Grimes Gallery and Track 16 Gallery, Los Angeles; itinerou para The Contemporary Arts Center, Cincinnati; University of South Florida Contemporary Art Museum, Tampa; The Bronx Museum of the Arts, New York, USA; Biblioteca Luis Ángel Arango, Bogotá, Colombia.

A Vuelta con los Sentidos, Casa de América, Madrid, Spain.

Um e Outro, Centro Cultural Banco do Brasil, Rio de Janeiro, Brasil.

Not There, Rena Bransten Gallery, San Francisco, USA.

Der Brazilianisch Blick, Haus Der Kulturen Der Welt, Berlin; itinerou para Ludwig Forum für Internationale Kunst, Aachen; Kunstmuseum Heidenheim, Heidenheim, Germany.

IV Foro Atlántico de Arte Contemporáneo, Pontevedra, Espanha.

Os 90, Paço Imperial, Rio de Janeiro, Brasil.

1998 XXIV Bienal Internacional de São Paulo, Pavilhão Ciccillo Matarazzo, São Paulo, Brasil.

Desde el Cuerpo: Alegorias de lo Feminino, Museo de Bellas Artes de Caracas, Caracas, Venezuela.

BIS, Galeria Camargo Vilaça, São Paulo, Brasil.

Fronteiras, Instituto Cultural Itaú, São Paulo, Brasil.

Anos 90: Coleção Gilberto Chateaubriand, MAM - Museu de Arte Moderna do Rio de Janeiro, Brasil.

Haus Der Kulturen Der Welt, Berlin, Germany.

1997 you are here, Royal College of Art, London, UK.

Esto Es: Arte Objecto y Instalación de Iberoamérica, Centro de Arte Contemporáneo, Mexico City, México.

Life's Little Necessities, 2nd Johannesburg Biennial, Johannesburg, South Africa Art Foundry Editions Santa Fe at Knoedler, Knoedler \& Company, New York, USA.

Tridimensionalidade na Arte Brasileira do Século XX, Instituto Itaú Cultural, São Paulo; Galeria Itaú Cultural,

Belo Horizonte; Galeria Itaú Cultural, Brasília; Galeria Itaú Cultural, Penápolis, Brasil. 
Así está la cosa: Instalación y Arte Objeto en América Latina, Centro Cultural Arte Contemporáneo, Mexico City, México.

19966 Women in Red, Galeria Luis Serpa, Lisboa, Portugal.

Collective Soul, Galleria Marabini, Bologna, Italy.

To Live Is to Leave Traces, Hospicio Cabanas, Guadalajara, México.

The Tailor's Dummy, Christopher Grimes Gallery, Los Angeles, USA.

Visions, Rhona Hoffman Gallery, Chicago, USA.

Camargo Vilaça Bis, Galeria Camargo Vilaça, São Paulo, Brasil.

Pequenas Mãos, Paço Imperial, Rio de Janeiro; Centro Cultural Alumni, São Paulo, Brasil.

Transparências, MAM - Museu de Arte Moderna do Rio de Janeiro, Rio de Janeiro, Brasil.

1995 Dark Room, Stark Gallery, New York, USA.

Anos 80: O Palco da Diversidade, Galeria de Arte do SESI, São Paulo, Brasil.

La Habana-São Paulo: Junge Kunst aus Lateinamerika, Haus Der Kulturen Der Welt, Berlin, Germany.

Espelhos e Sombras, Centro Cultural Banco do Brasil, Rio de Janeiro, Brasil.

The Education of the Five Senses, White Columns, New York; itinerou como L'Educazione dei Cinque Sensi, Palazzo Pamphili, Rome, Italy.

Longing and Belonging, Site Santa Fe, Santa Fe, USA.

Brasil na Bienal, Galeria da Universidade Federal Fluminense, Niterói, Brasil.

1994 XXII Bienal Internacional de São Paulo, Fundação Bienal de São Paulo, São Paulo, Brasil.

Perception, Information Gallery, New York, USA.

A Fotografia Contaminada, Centro Cultural São Paulo, São Paulo, Brasil.

Espelhos e Sombras, MAM - Museu de Arte Moderna de São Paulo, São Paulo, Brasil.

Escultura Carioca, Paço Imperial, Rio de Janeiro, Brasil.

International Critic's Choice, Tarble Arts Center, Eastern Illinois University; itinerou para University Museum, Southern Illinois University, Carbondale, USA. 
Brasil Hoy, Galería Valenzuela Klenner, Bogota, Colombia.

6 Artistas, Galeria Camargo Vilaça, São Paulo, Brasil.

1993 ABC: Contemporary Art from Argentina, Brazil and Colombia, Sidney Mishkin Gallery, Baruch College, New York, USA.

Artist in the Marketplace: Thirteenth Annual Exhibition, The Bronx Museum of the Arts, New York, USA.

International Critic's Choice, Mitchell Museum, Mount Vernon, USA.

Língua Latina Regina Est, Stux Gallery, New York, USA.

A Presença do Ready-Made 80 Anos, MAC USP - Museu de Arte Contemporânea da Universidade de São Paulo, São Paulo, Brasil.

1992 Galeria Camargo Vilaça, São Paulo, Brasil.

Programa Anual de Exposições de Artes, Fundação Bienal de São Paulo, São Paulo, Brasil.

Polaridades e Perspectivas, Paço das Artes, São Paulo, Brasil.

1991 IV Bienal de la Habana, Havana, Cuba

Imagem sobre Imagem, Espaço Cultural Sérgio Porto, Rio de Janeiro, Brasil.

Casa Triângulo, São Paulo, Brasil.

XXII Panorama de Arte Atual Brasileira, MAM - Museu de Arte Moderna de São Paulo, São Paulo, Brasil.

7 x Ar, MAM - Museu de Arte Moderna do Rio de Janeiro, Rio de Janeiro, Brasil.

EAV Processo nº738.765-2, Funarte, Rio de Janeiro, Brasil.

80/90 Formas Tridimensionais: A Questão Orgânica, Museu Municipal de Arte, Curitiba, Brasil.

Programa de Exposições de Artes Plásticas, Centro Cultural São Paulo, São Paulo, Brasil.

Salão Carioca de Artes Plásticas, Escola de Artes Visuais do Parque Lage, Rio de Janeiro, Brasil.

1990 VII Salão Paulista de Arte Contemporânea, São Paulo, Brasil.

Possível Imagem, Solar Grandjean de Montigny, Rio de Janeiro, Brasil.

Aqueous, Fundição Progresso, Rio de Janeiro, Brasil. 
1989 XI Salão Nacional de Artes Plásticas, Funarte, Rio de Janeiro, Brasil.

1988 XX Salão Nacional de Artes Plásticas, Museu de Arte Moderna, Belo Horizonte, Brasil.

1987 I Bienal de Escultura ao Ar Livre, Escola de Artes Visuais do Parque Lage, Rio de Janeiro, Brasil.

\section{Prêmios}

2014 Pacific Standard Time: LA/ LA, The Getty Foundation, Los Angeles, USA.

2005 Anonymous Was a Woman Award, New York, USA.

2003/04 MIT, Ida Ely Rubin Artist in Residence Program, Massachusetts Institute of Technology, Cambridge, USA.

1996 John Simon Guggenheim Memorial Fellowship, New York, USA.

\section{Coleções Públicas}

Albright-Knox Art Gallery, Buffalo, USA.

Bronx Museum of the Arts, Bronx, USA.

Burger Collection, Zürich, Switzerland

Carnegie Museum of Art, Pittsburg, USA.

Centro Galego de Arte Contemporânea, Santiago de Compostela, Spain.

Cisneros Fontanals Art Foundation, Miami, USA.

Corcoran Gallery of Art, Washington DC, USA.

Dallas Museum of Art, Dallas, USA.

Daros Foundation, Zürich, Switzerland

Fundação Itaú Cultural, São Paulo, Brasil.

Fundación "la Caixa", Barcelona, Spain.

Hirshhorn Museum and Sculpture Garden, Washington DC, USA.

Instituto Inhotim, Brumadinho, Brasil.

Katzen American University Museum, Washington, DC, USA.

Laumeier Sculpture Park, Saint Louis, USA.

Los Angeles County Museum of Art, Los Angeles, USA. 
Museu de Arte Contemporânea da Universidade de São Paulo, São Paulo, Brasil.

Museu d'Art Contemporani de Barcelona, Barcelona, Spain.

Museu de Arte Moderna de São Paulo, São Paulo, Brasil.

Museu de Arte Moderna do Rio de Janeiro, Rio de Janeiro, Brasil.

Museu Arte de Pampulha, Belo Horizonte, Brasil.

Museo de Arte Contemporânea, Monterrey, México.

Museu Extremeño e Iberoamericano de Arte Contemporâneo, Badajoz, Spain.

Museum of Contemporary Art, San Diego, USA.

Pinacoteca do Estado de São Paulo, São Paulo, Brasil.

Solomon R. Guggenheim Museum, New York, USA.

Tate Modern, London, UK

The MINT Museum of Art, Charlotte, USA.

The National Museum of Women in the Arts, Washington DC, USA.

The Phillips Collection, Washington DC, USA.

The Progressive Art Collection, Mayfield Village, USA.

The MINT Museum of Art, Charlotte, USA.

The National Museum of Women in the Arts, Washington DC, USA.

The Phillips Collection, Washington DC, USA.

The Progressive Art Collection, Mayfield Village, USA. 


\section{II - Tradução de The Look of Love, $1967^{26}$.}

The Look Of Love

The look of love

Is in your eyes.

A look your smile

Can't disguise.

The look of love,

It's saying so much more than

These words could ever say.

And when my heart has hurt,

Well, it takes my breath away.

I can hardly wait to hold you,

Feel my arms around you.

How long I have waited,

Waited just to love you,

Now that I have found you.

You've got that look of love.

It's on your face.

The look that time can't erase.

You're mine tonight.

Let this be just the start of

So many nights like this.

Let's take what lover's found

And then seal it with a kiss.

I can hardly wait to hold you,

Feel my arms around you.

How long I have waited,

Waited just to love you,

Now that I have found you,

Don't ever go.

Don't ever go.

I love you so.
A Aparência do Amor

A aparência do amor

Está em seus olhos

Uma aparência que seu sorriso

Não pode disfarçar

A aparência do amor

Está dizendo muito mais do que

Estas palavras jamais poderiam dizer

E quando meu coração estava ferido

Bem, isso me tira o fôlego

Mal posso esperar para te abraçar

Sinta meus braços ao seu redor

Quanto tempo eu esperei

Esperei apenas para te amar

Agora que eu encontrei você

Você tem aquela aparência do amor

Está na sua cara

A aparência que o tempo não apaga

Você é meu hoje à noite

Que este seja apenas o começo de

Tantas noites como esta

Vamos achar o que os amantes procuram

E depois selar isso com um beijo

Mal posso esperar para te abraçar

Sinta meus braços ao seu redor

Quanto tempo eu esperei

Esperei apenas para te amar

Agora que eu encontrei você

Nunca vá embora

Nunca vá embora

Eu te amo tanto

26 Burt Bacharach. The Look of Love. Disponível em: https://www.letras.mus.br/burtbacharach/2755/traducao.html. Acesso 03 dez. 2017. 